اتجاهات جمهور الخبراء نحو الصحافة الإقليمية في صعيد مصر .. دراسة ميدانية

اتجاهات جمهور الفبراء نـو الصحافة الإقليمبة في صعيد مصر

\title{
دراسة ميدانبة
}

نانسي صالح سالم ضيف الله

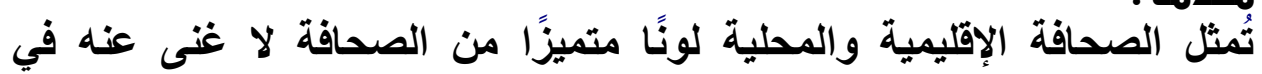

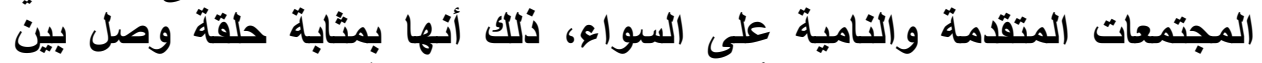

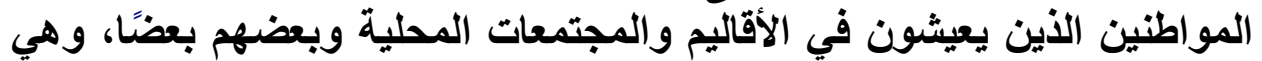

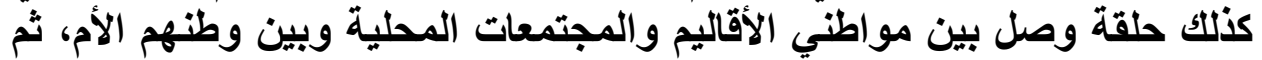

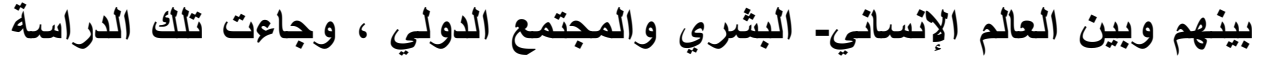

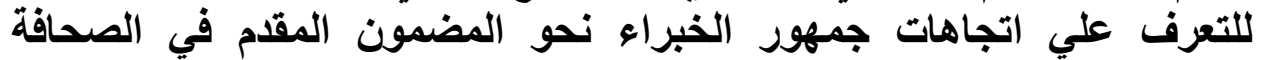
الإقليمية في صعيد مصر .

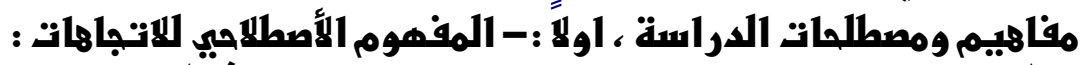

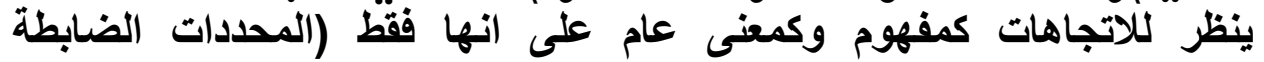

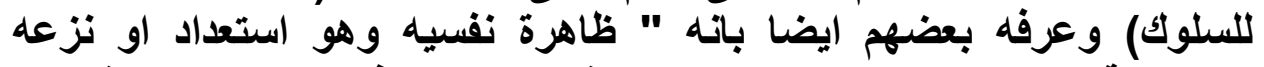

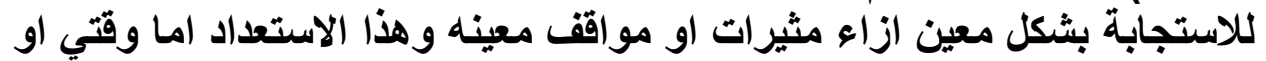

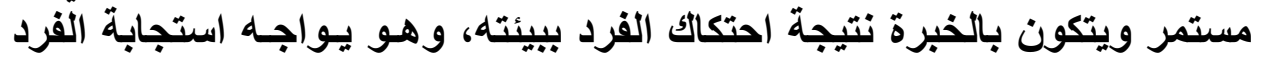

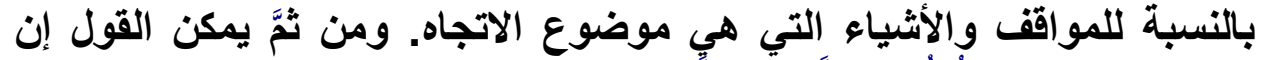

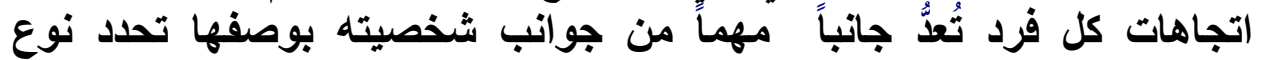

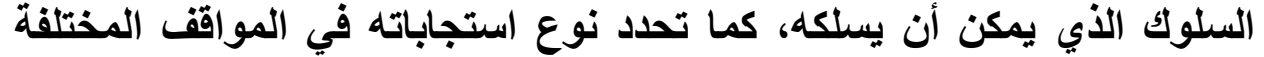

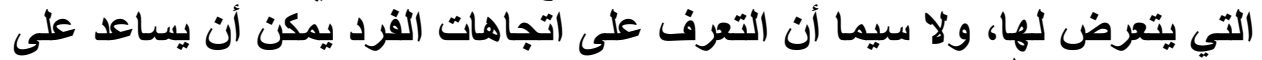

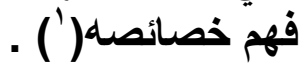
وتعرف الباهنة الانتجاله اجرائباً: تعزف الباحثة الاتجاه حسب موضباء موضوع الاراسة هو الموقف الأبي يقفه

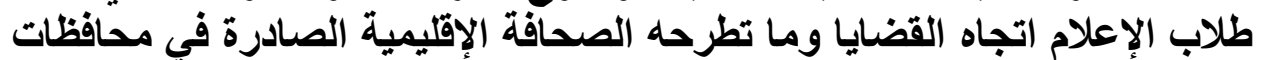
الاراسة.

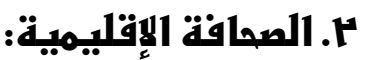

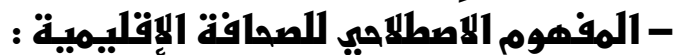

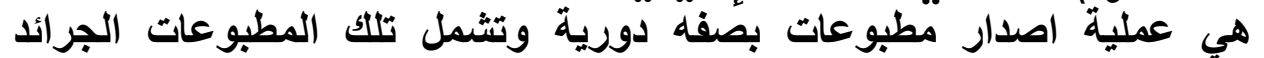
والمجلات العامة والمتخصصة التي تختلف في دوريتها من يومية الى اسبوعية

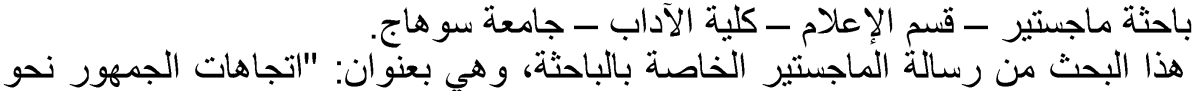

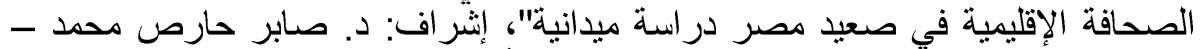

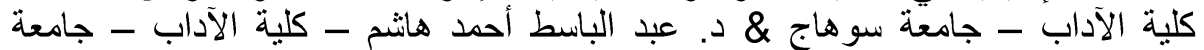

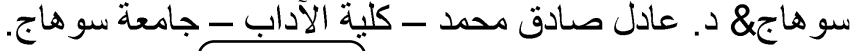




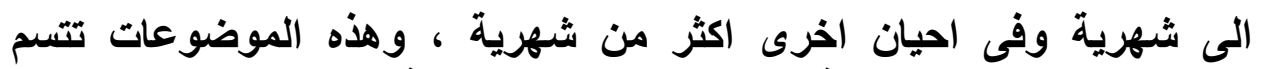

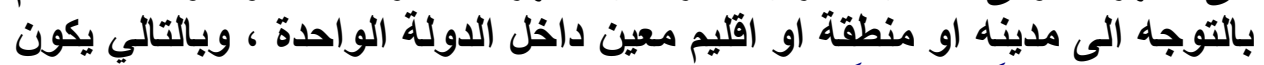

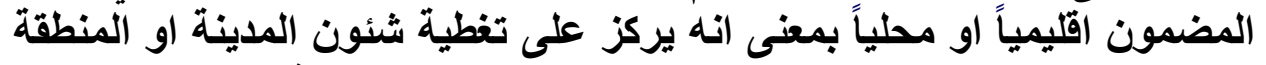

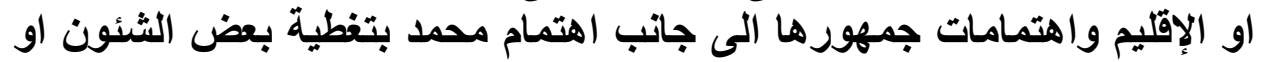

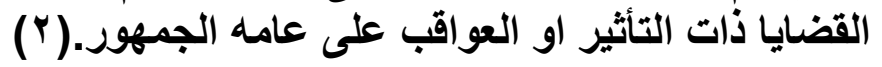

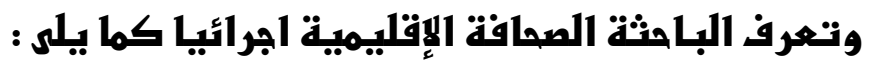

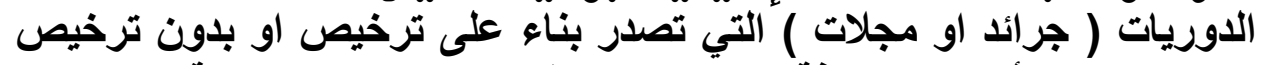

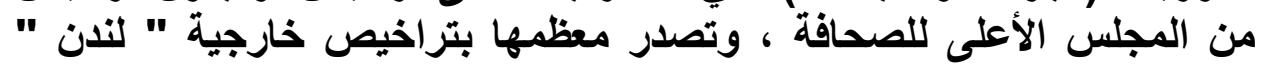

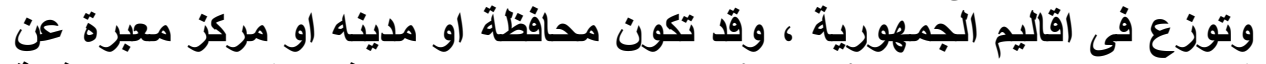

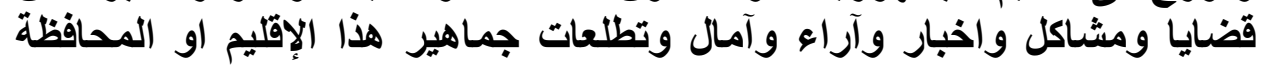

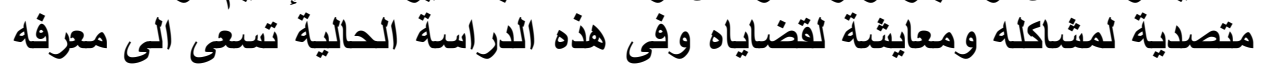
اتجاهات جمهور الصعيد نحو الصحائة لفوائة الإقليمية

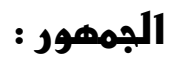
تعرف الباحثة الجمهور اجرائياً ، حيث طبقت الباحثة علي جمهور الخبراء

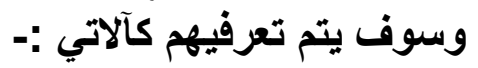

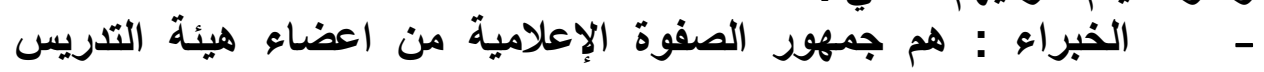

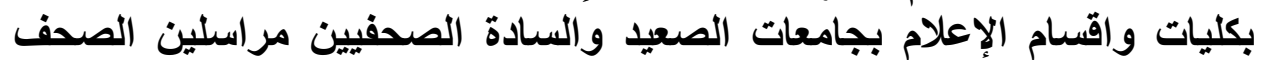

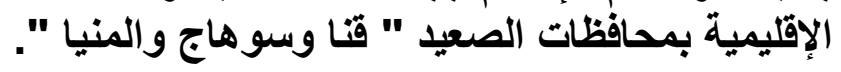

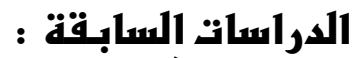

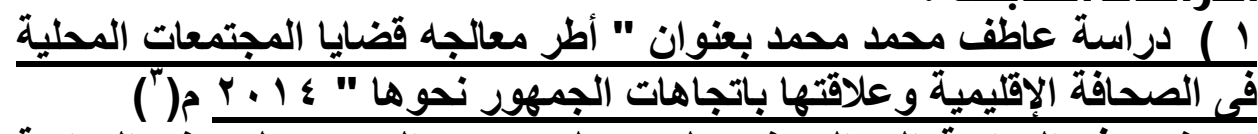

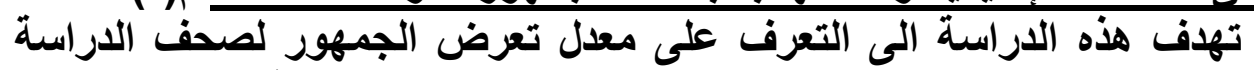

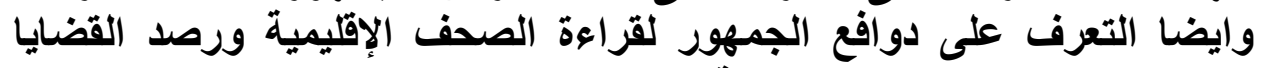

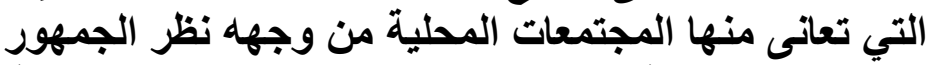

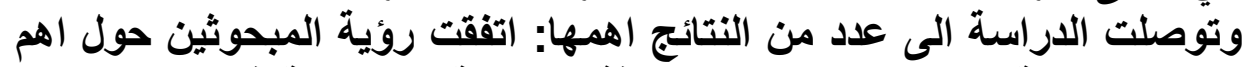

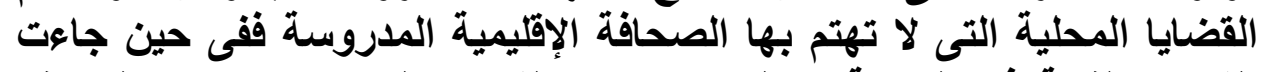

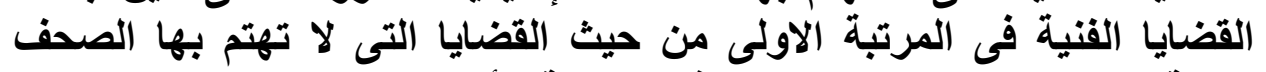

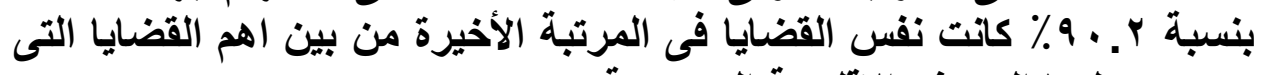

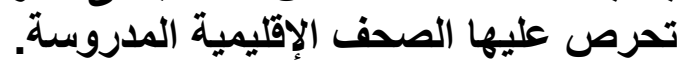

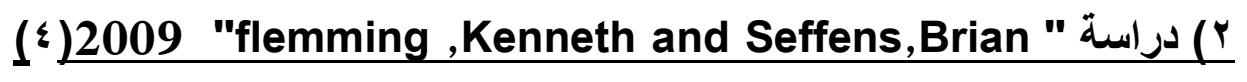

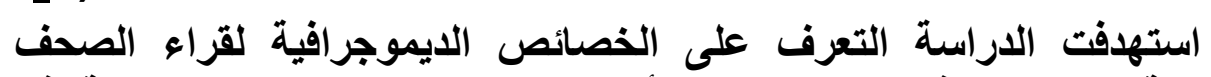

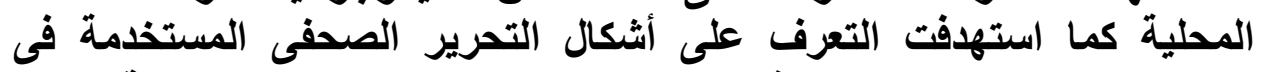

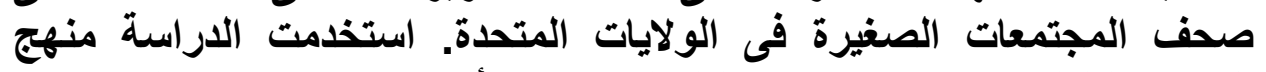
المسح بالتليفون كما استخدمت تحليل المضمون كأداة من ادوات المات جمع البيانات. 
توصلت الدراسة الى عدد من النتائج اهمها :ان الصحف المحلية تعتبر مصدراً

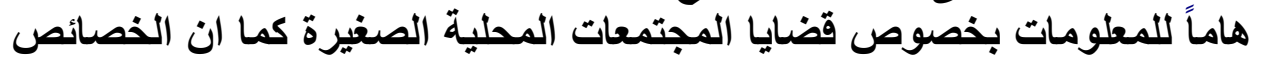

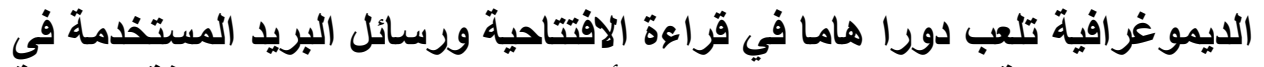

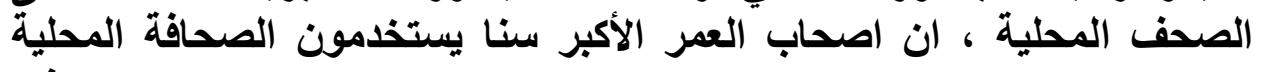

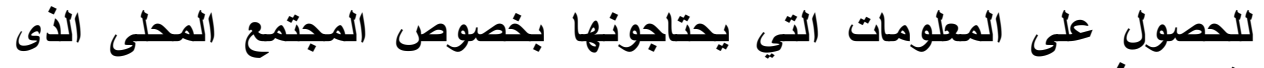
يقيمون فيه والم) دراسة أميمة عمران محمد بعنوان " القائم بالأتصال فى الصحافة الإقليمية

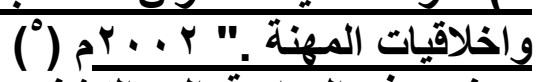

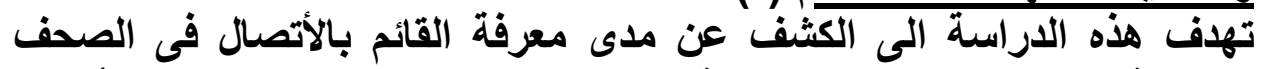

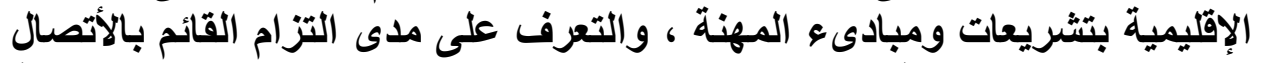

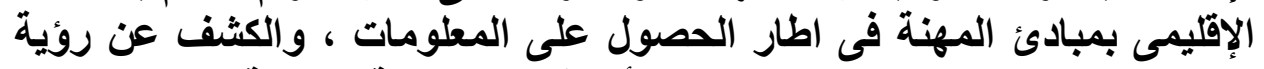

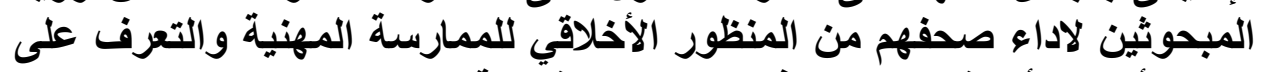

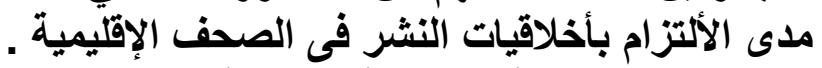

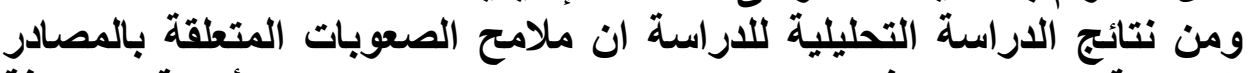

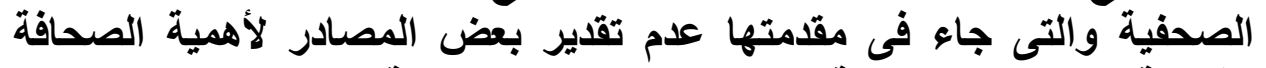

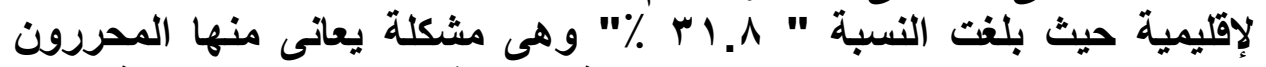

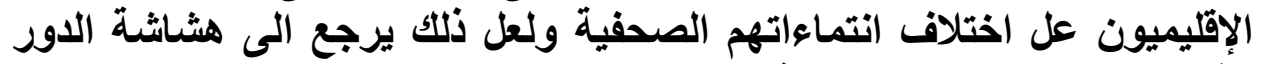

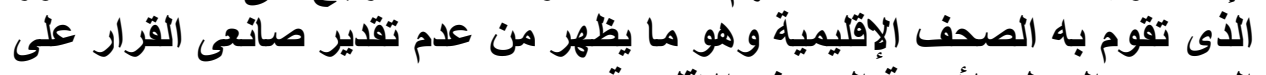

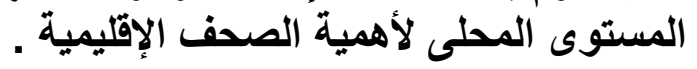

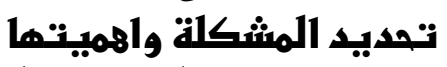
بعد رصد الاراسات السابقة استخلصت الباحثّه عدة مؤشرات ساعدتها في

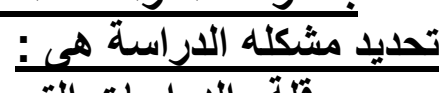

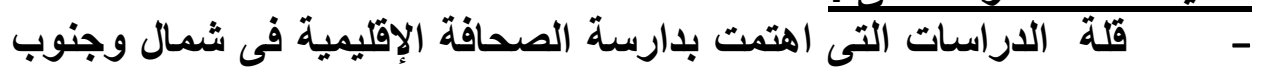
الصعيد .

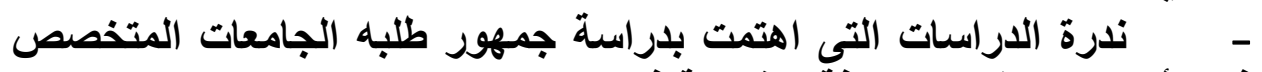

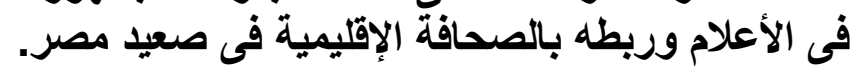

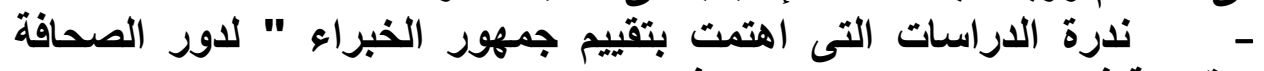

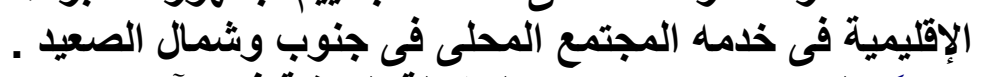

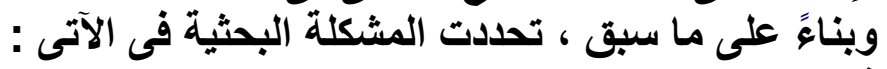

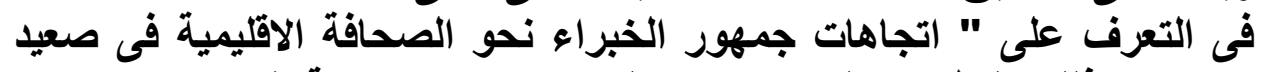

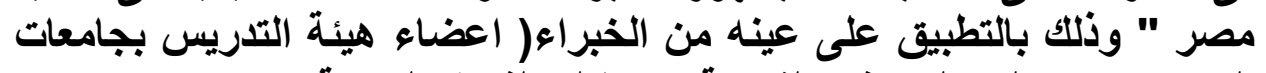

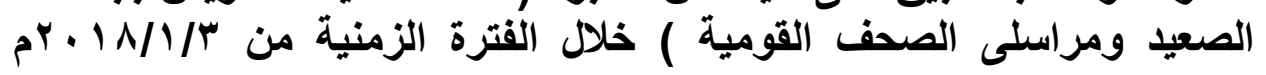

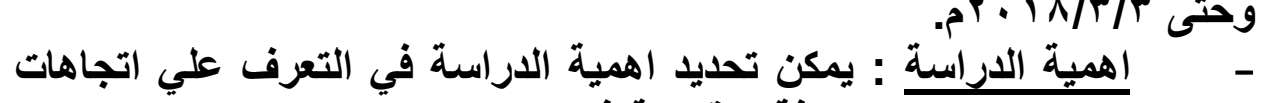

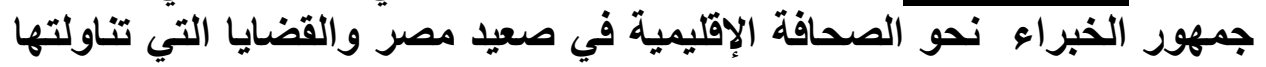


الصحافة الإقليمية في صعيد مصر حيث اصبحت الصحافة الاقليمية التى تصدر

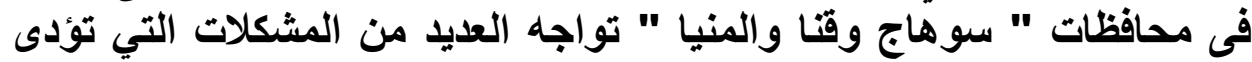

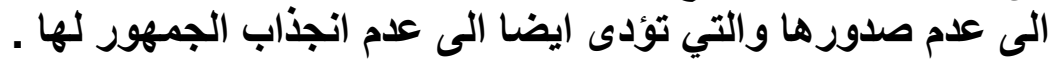

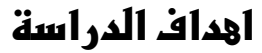

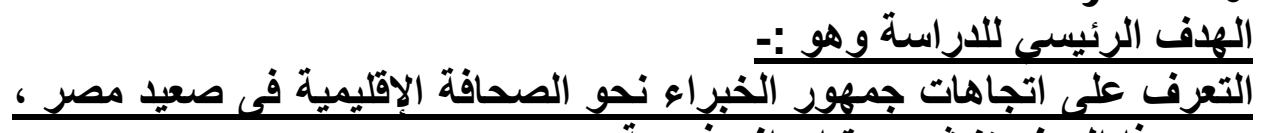

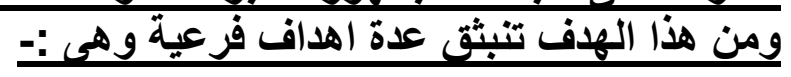

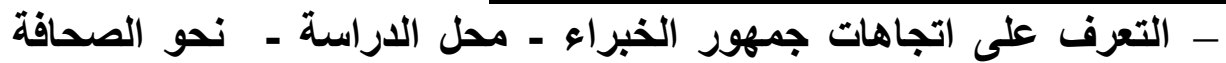

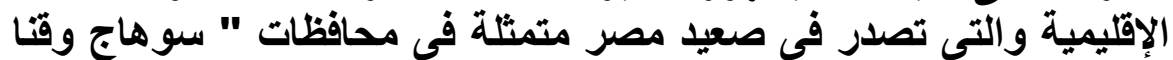

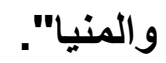

- التعرف على تأثير الاعلانات التى تنشرها الصحف الإقليمية على المضمون

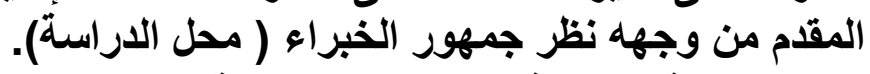

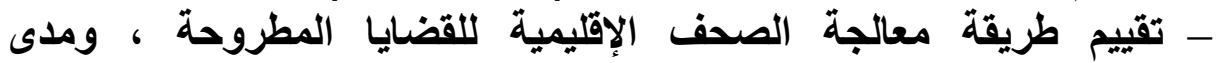

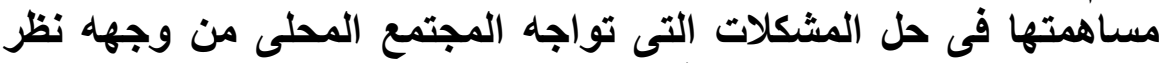

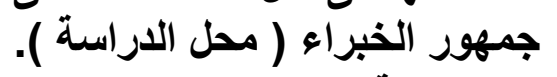

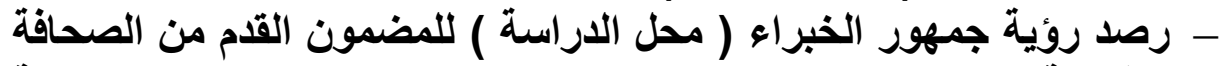

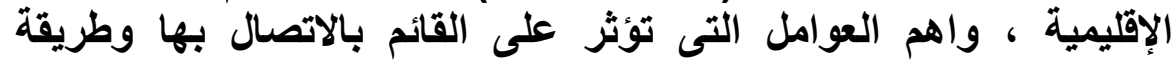

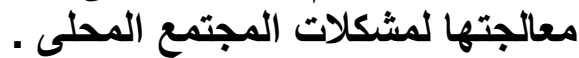

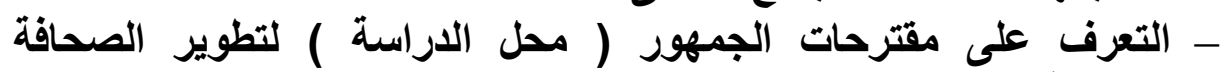
الاقليمية فى صعيد مصر وتفعيل دورها فئى خدمه المجتمع المحلى . تسساؤلات الدراستة :

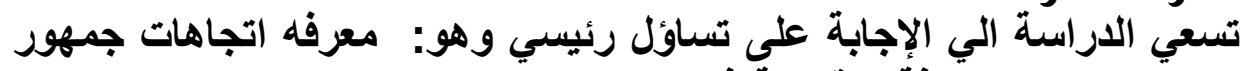

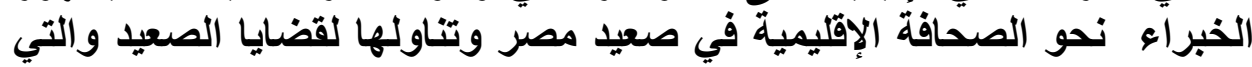

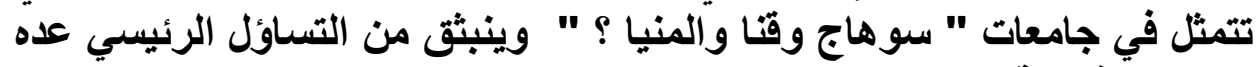
: تساؤلات فرعية وهي وهي

ا ـ ما تقييم المضمون المقدم من الصحافة الإقليمية من وجهاه نظر الخبراء؟

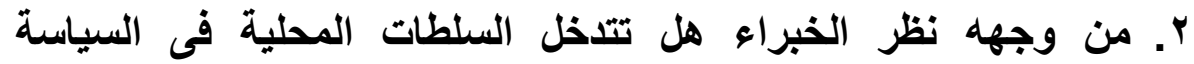

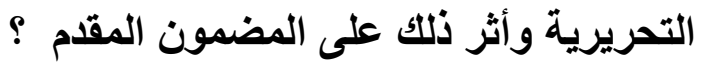

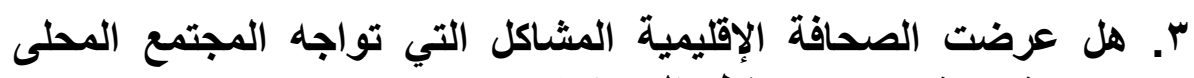

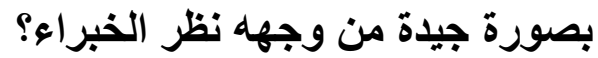

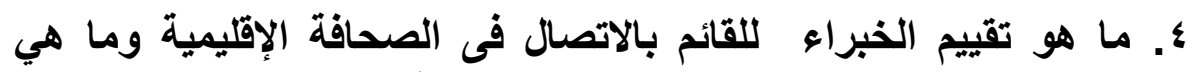

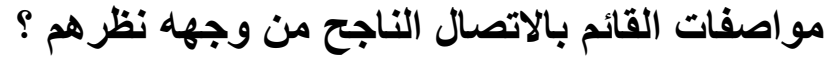


اتجاهات جمهور الخبراء نحو الصحافة الإقليمية في صعيد مصر .. دراسة ميدانية

๑. هل اسلوب جلب الإعلانات للصحف الإقليمية اثر على المضمون المقدم

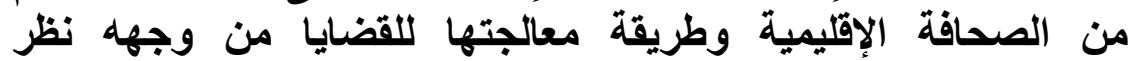
الخبر اء؟

7 ا. من وجهه نظر الخبراء هل تعرض الصحافة الإقليمية للمشكلات التي

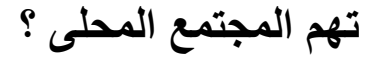
V. ما اهم المقترحات لتطوير الصحافة الإقليمية فى صعيد مصر وتفع وتفيل

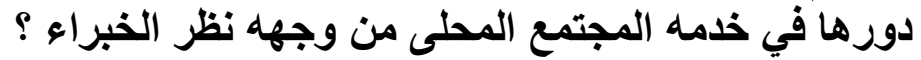

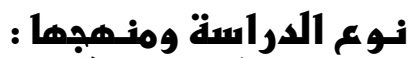

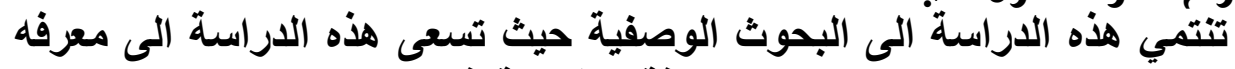

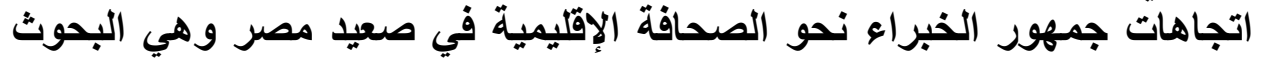
التي تهتم بلراسة واقع الأحداث والظواهر والمواقف وتحليلها ، وتفسيرها

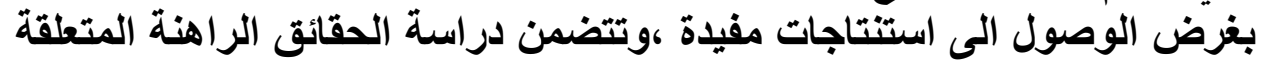

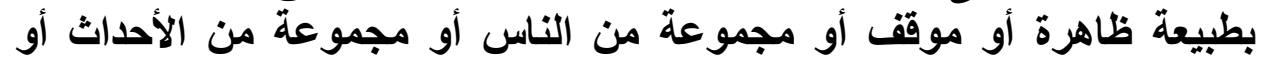

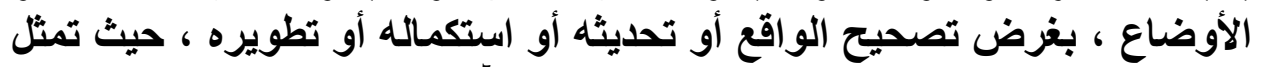

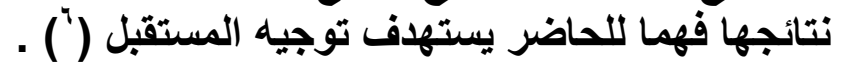

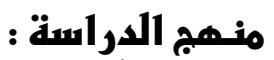
تعتمد هذه الاراسة التي امامنا على المنهج المسح الإعلامي ويعتمد على

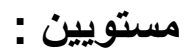
المستوى الوصفي : يثّ : قامت الباحثة بمسح التراث العلمي والاراسات

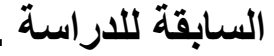
المستوى التحليلي : عن طريق مستح عينه من جمهور الخبراء من السادة

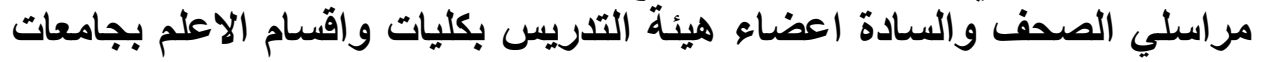
الصعيد اداة جمع البيانات :

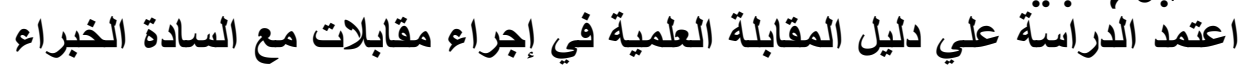

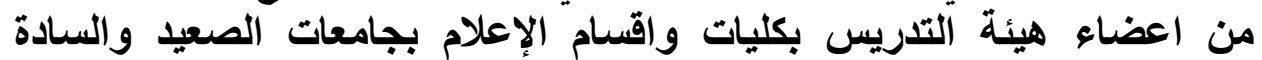
مراسلي الصحف القومية . مينة الصنية

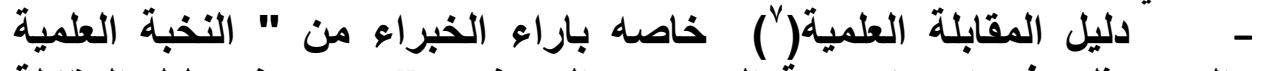

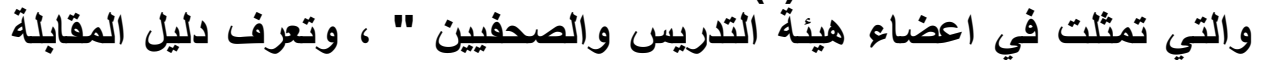

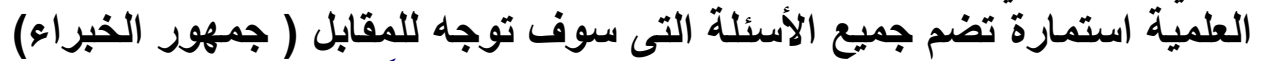

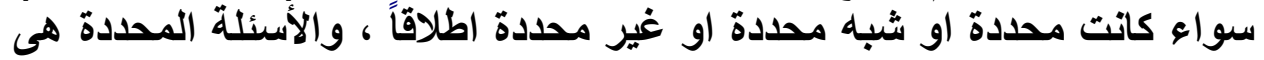

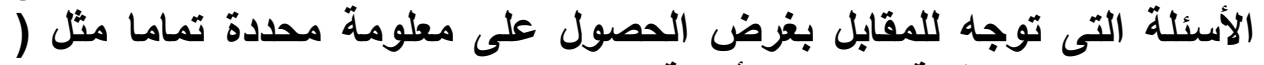

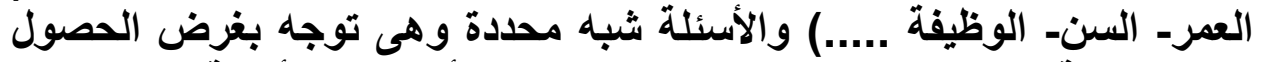

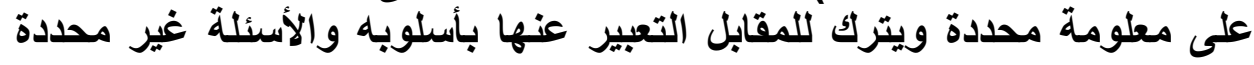


اطلاقاً فهي التي تهذف للحصول على المعلومة بواسطة معلومة او معلومات

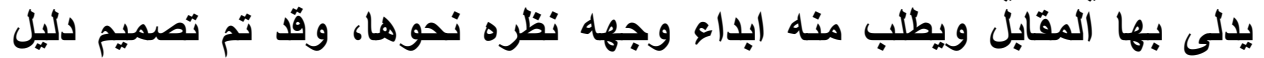

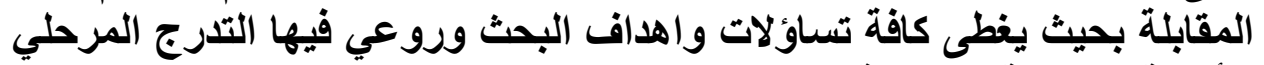

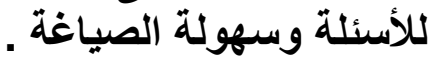

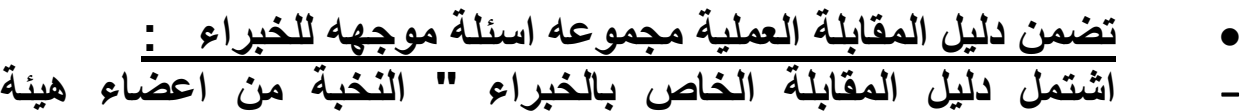

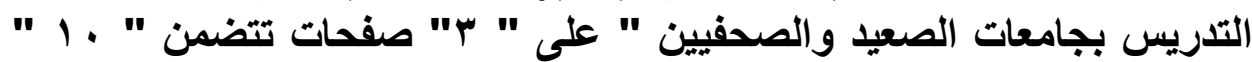

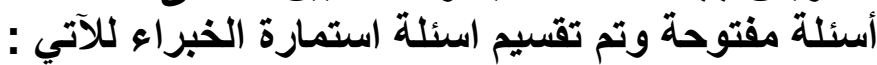

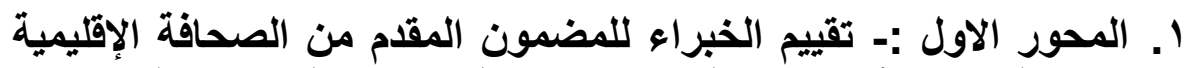

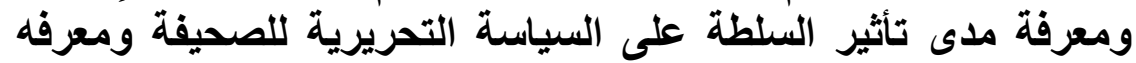
هل اسلوب جلب الإعلانات للصحيفة اثر على المضمون المقدم للجمهور.

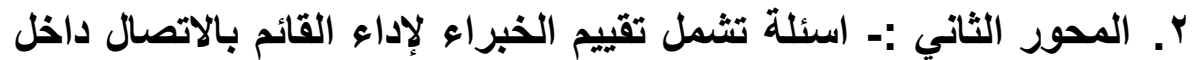

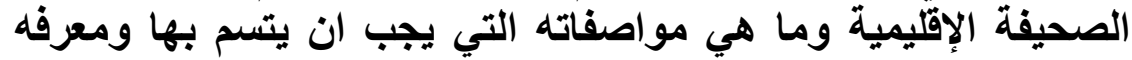

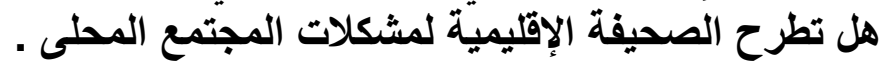

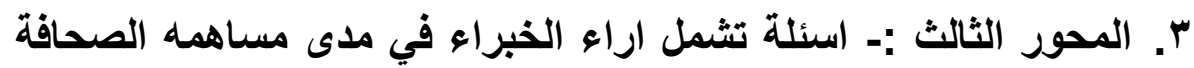

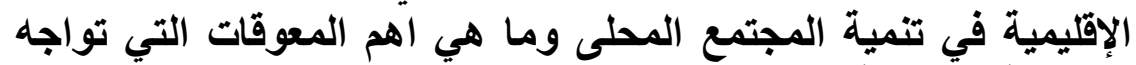

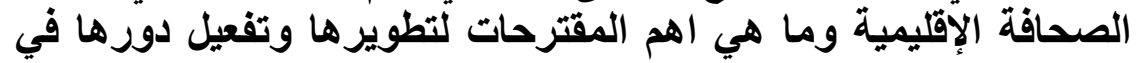

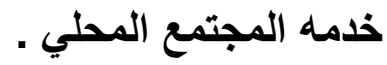

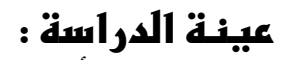
يتراوح الأسلوب المتبع في دراسة مفردات مجتمع البحث ما بين العينة

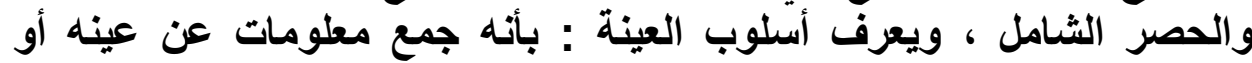

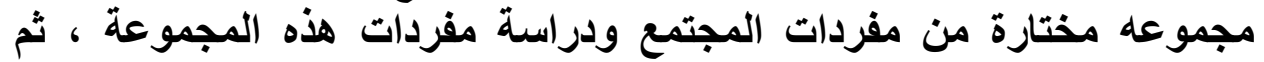

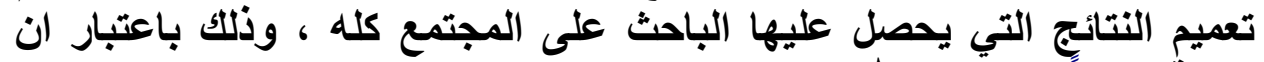

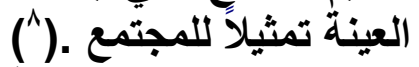

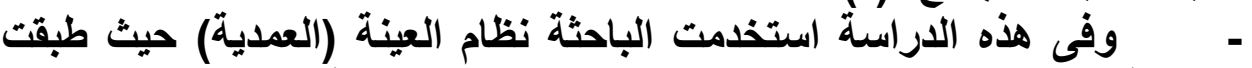

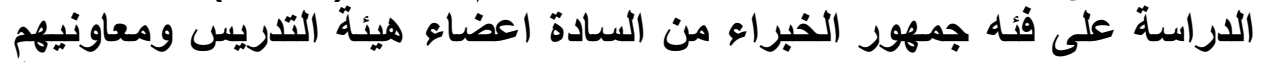

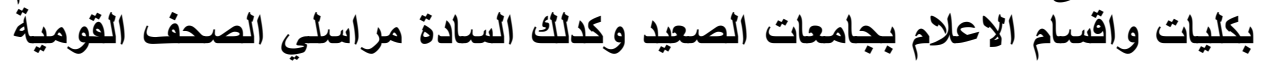

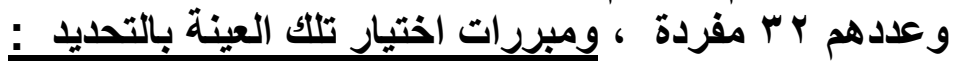

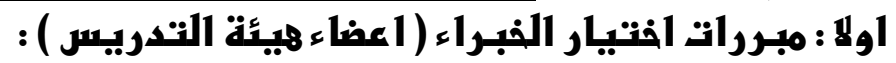
ا- - الانهم الأقر على تقييم المضمون الصحفي من الناحية العلمية

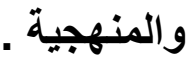
r- معرفتهم للكثير من الصحف الإقليمية والقائمين عليها وقدرتهم على الصن

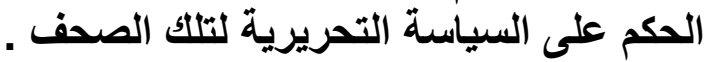




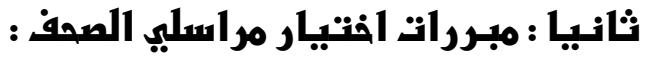
1. لانهم الاكثر قدرة على تقييم المضمون الصحفي من حيث الخبرة العملية

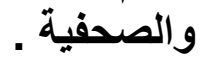

r r ا ثرافهم على العديد من الصحف الإقليمية في بعض الأحيان .

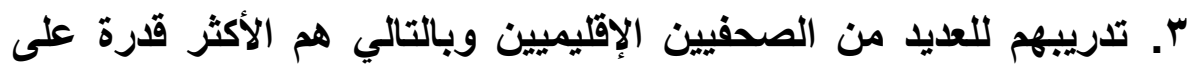

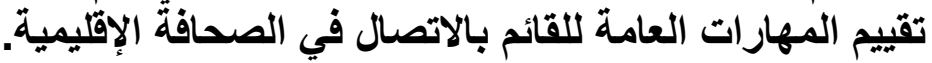

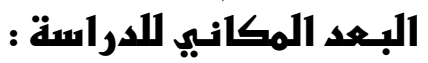
- يشمل البعد المكاني للاراسة ، شمال ووسط وجنوب الصني الصعيد ، كالتالي :

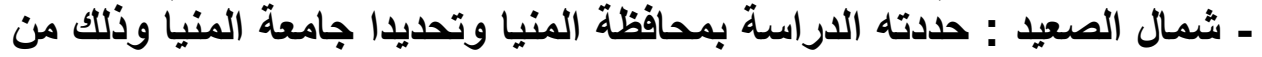
خلال تطبيق الدارسة على اعضاء هيئة التدريس بكلية الآداب قسم الاعلام بجامعه المنيا.

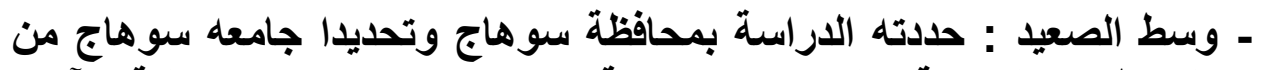
خلال تطبيق الاراسة على اعضاء هيئة التدريس بقسم الاعلام كلية الآداب

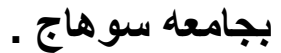
- جنوب الصعيد : حددته الدراسة بمحافظة قنا وتحديدا جامعه جنوب الوادي

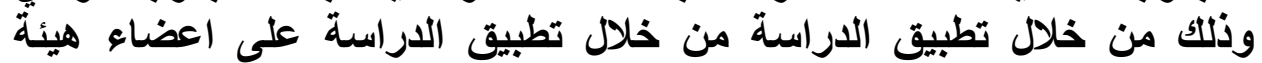
التدريس بكلية الاعلام بجامعه جنوب الوالئ منادي.

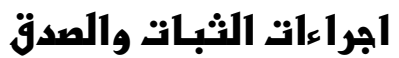

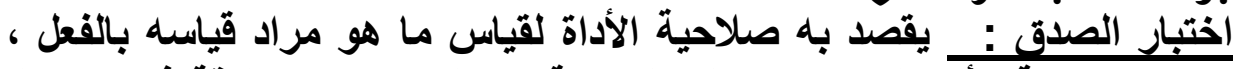

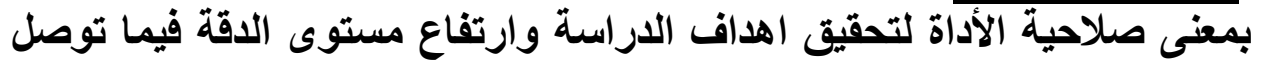

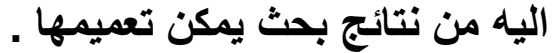

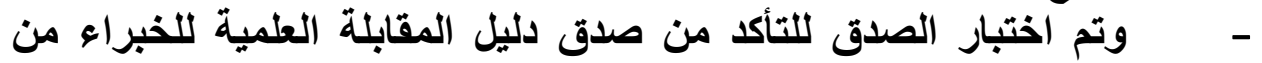

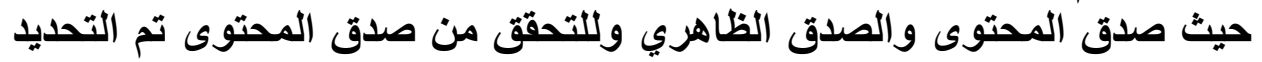

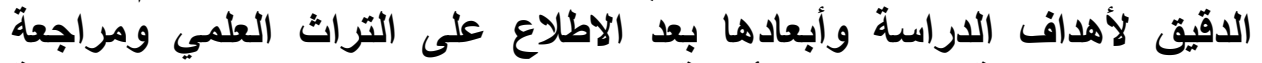

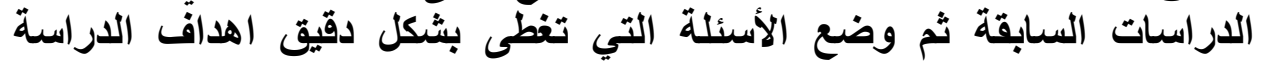

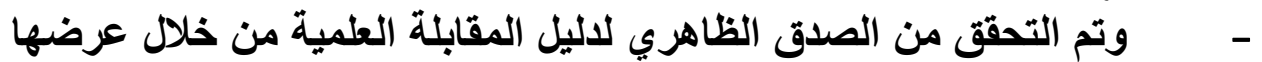

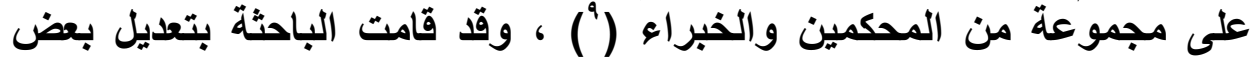

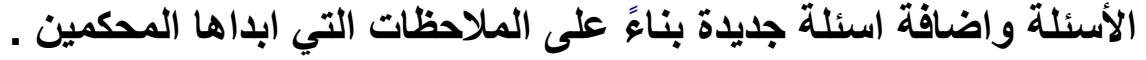

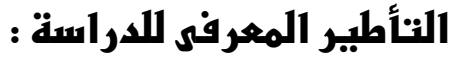

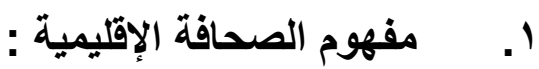
r. المثكلات التي تواجه الصحافة الإقليمية فى صعيد مصر . . 


\section{اولاً : - مفهوم الصحافة الإقلبمية :}

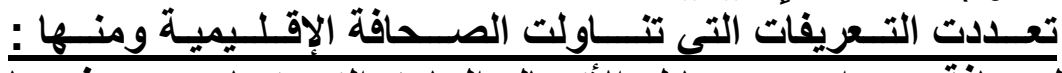

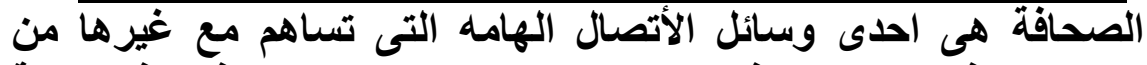

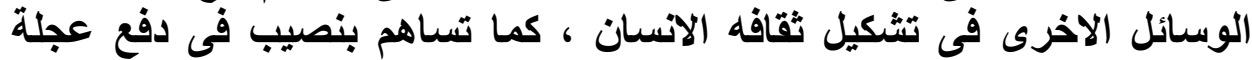

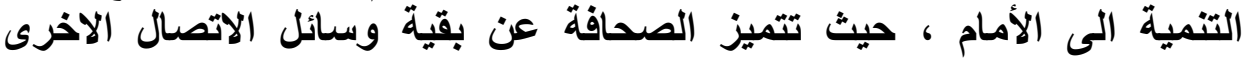

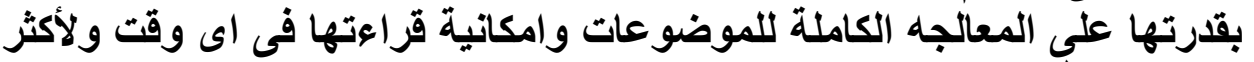

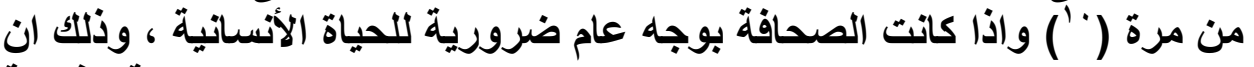

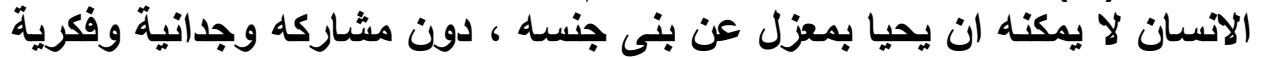

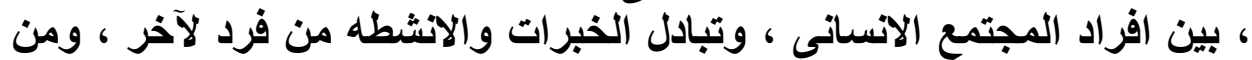

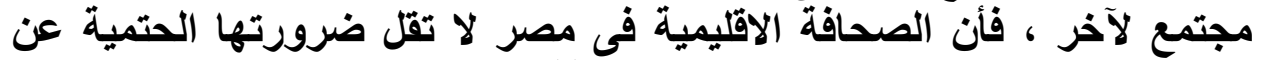

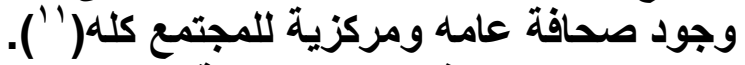

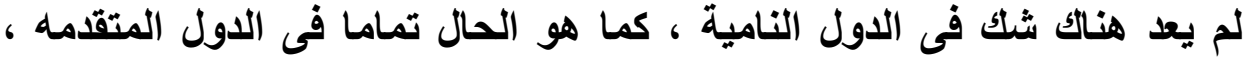

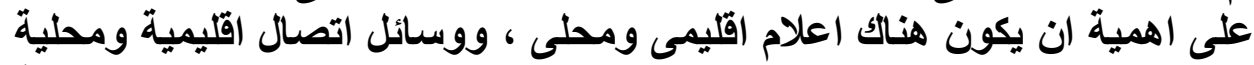

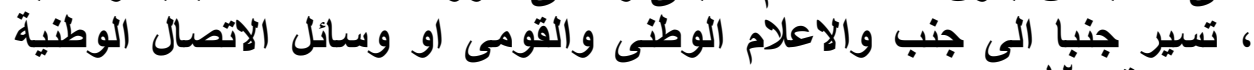

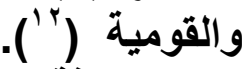
ان الصحافة الاقليمية تهتم بالموضوعات ذاتهات الطابع القومى كوسيلة اتصال

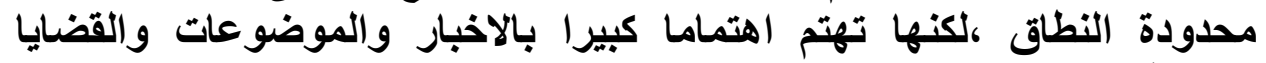

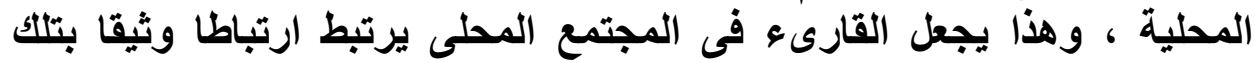
الصحف .

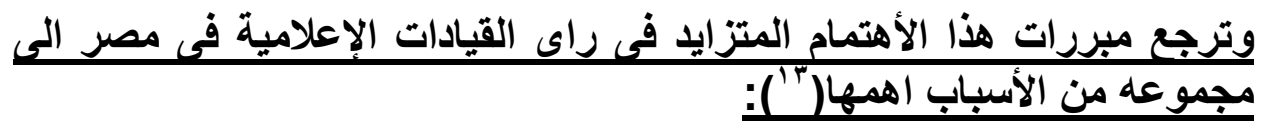

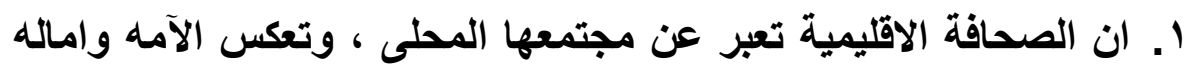

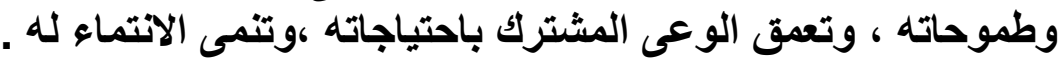

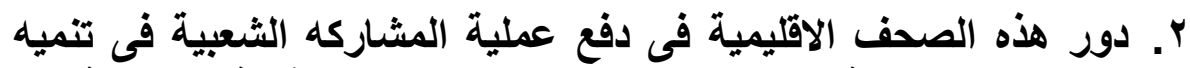

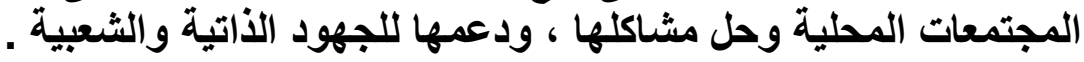

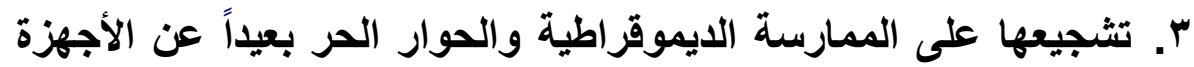

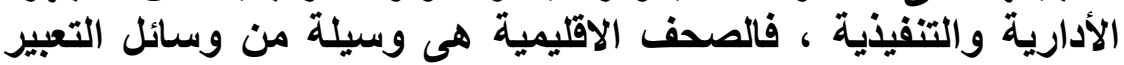

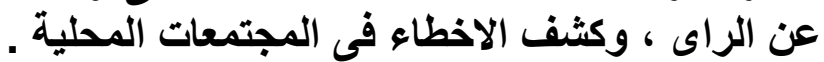

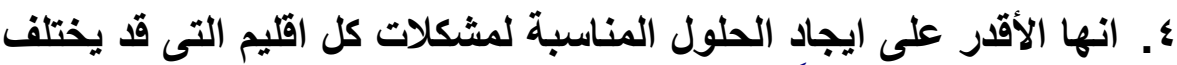

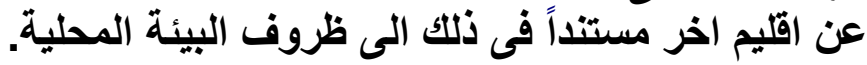

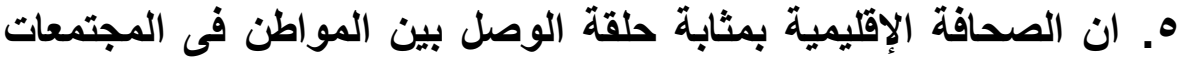

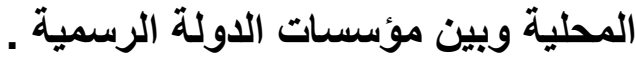




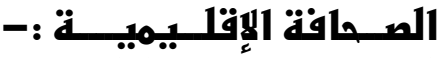
لما كاتت رموز الكلمات تتسم بالمرونه والتعقيدات الى درجه كبيرة ، ومن الته

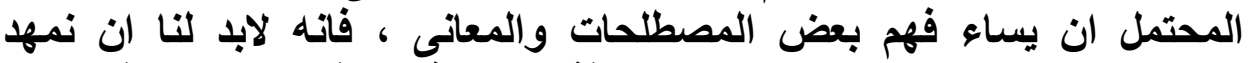

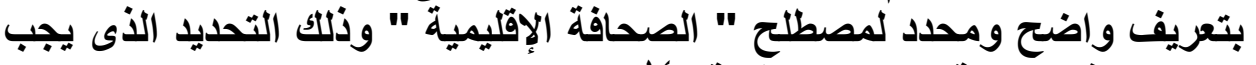

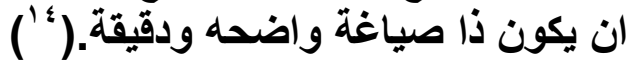

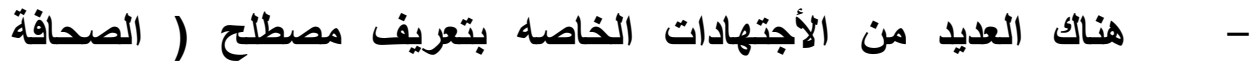

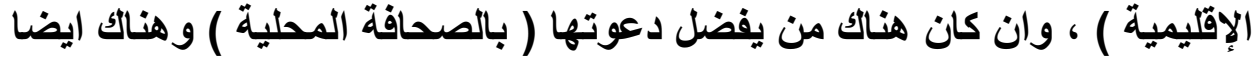

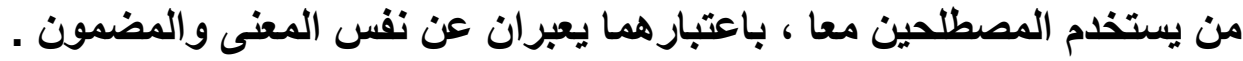

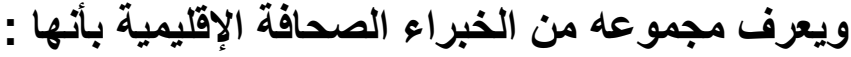

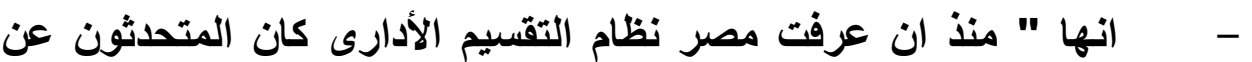

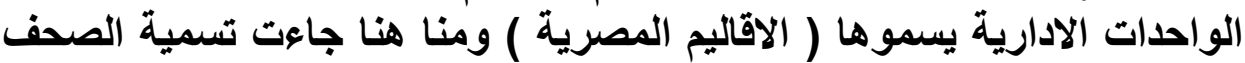

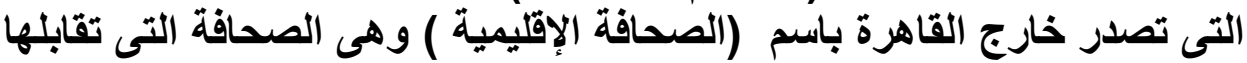

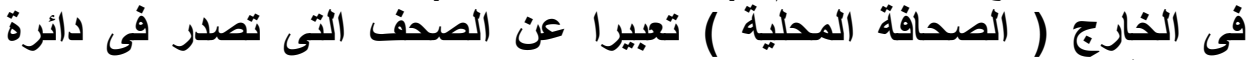

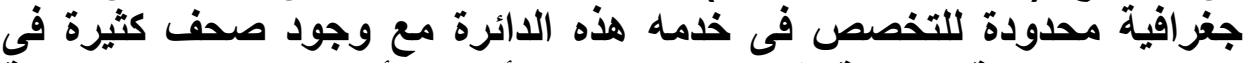

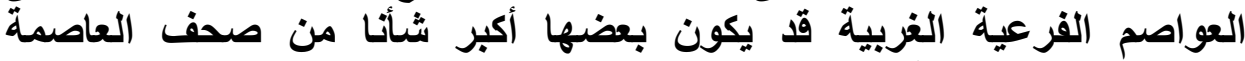

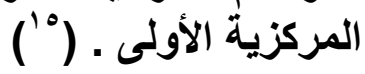

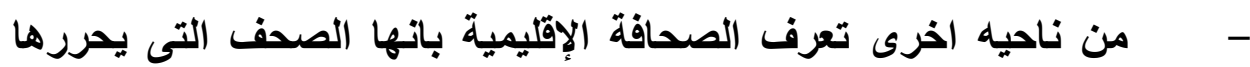

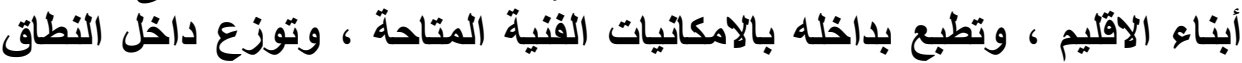

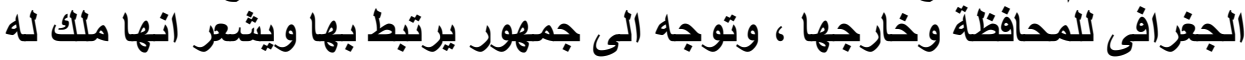

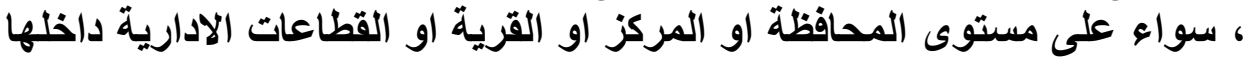

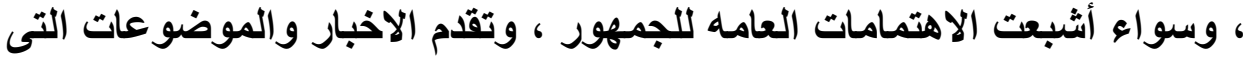

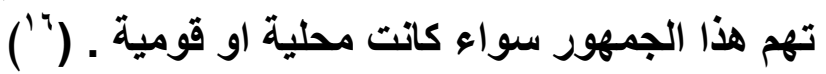

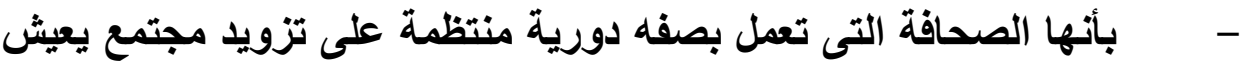

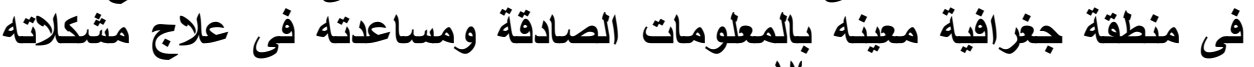

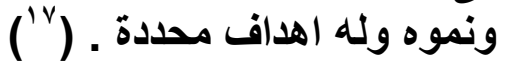

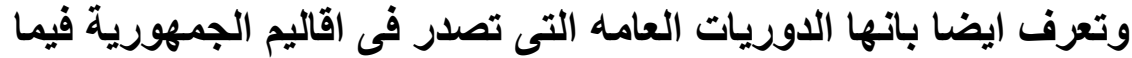

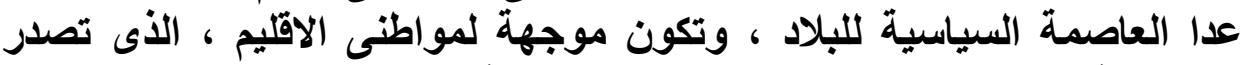
وتوزع فيه ، معبرة عن مشاكل جماهير هذا الاقليم ، واخبارها هونة وآرائها

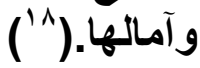
فرق " عماد الدين عثمان " فحى دراسة له بين ثلاثة انواع من

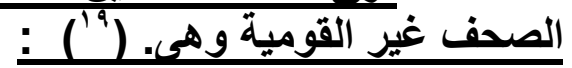

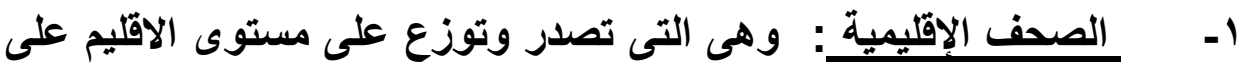

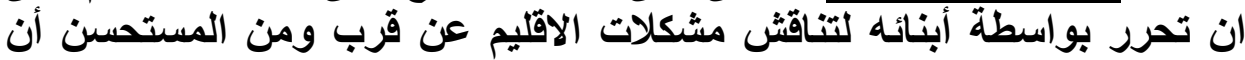




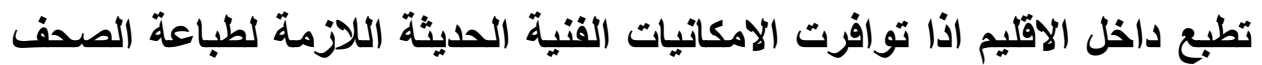

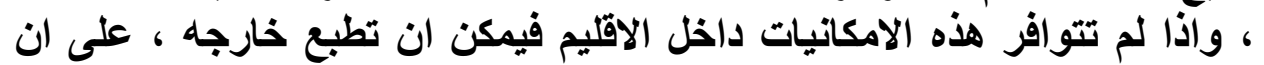

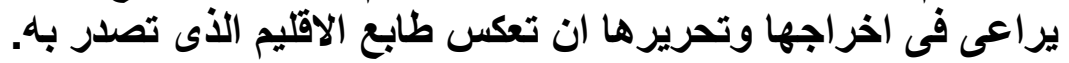

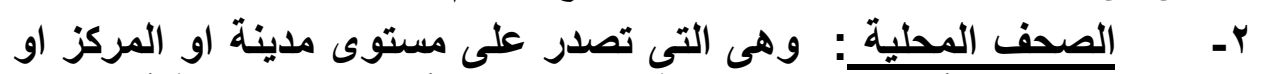

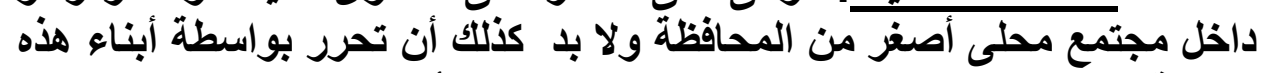

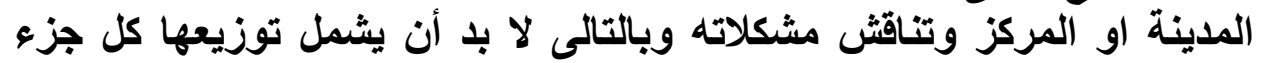

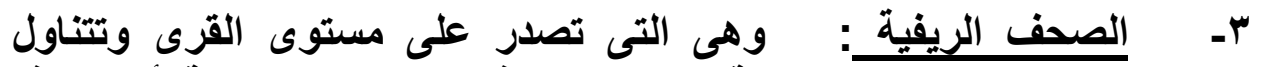

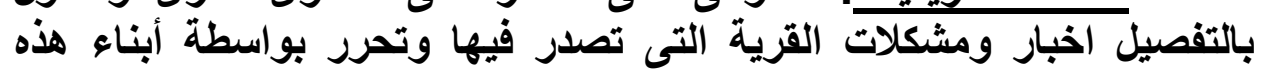

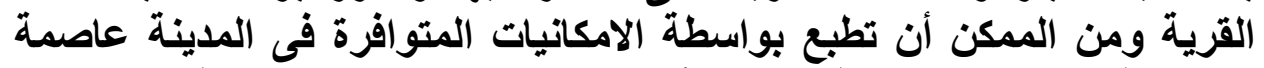

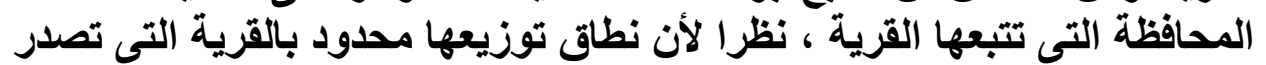

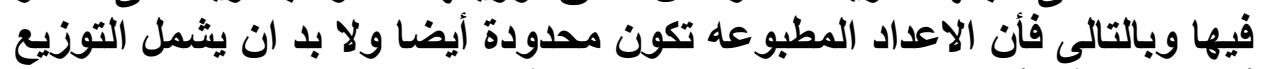

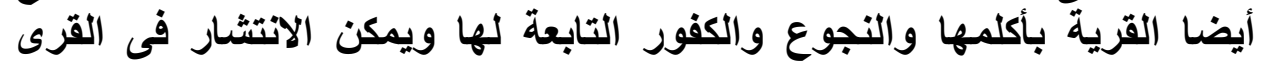
المجاورة .

- وتعرف ايضا بأنها عملية اصدار مطبوعات بصفه دورية وتشمل تلكاتل

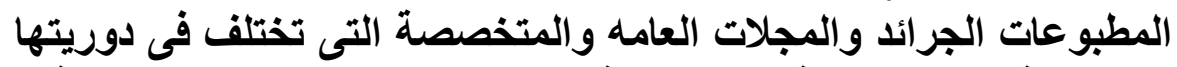

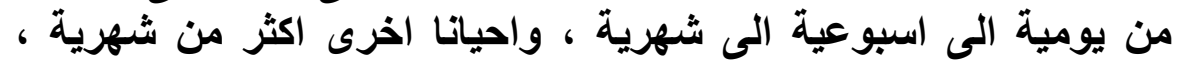

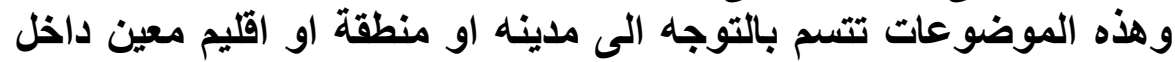

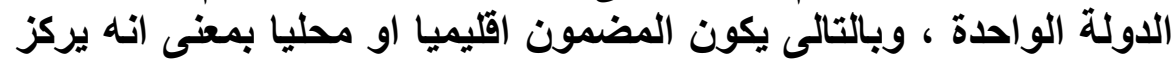

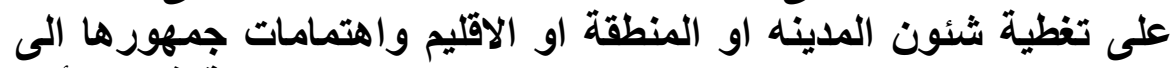

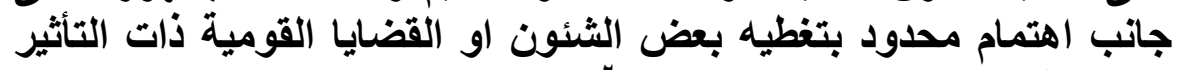

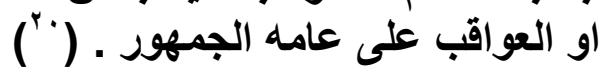

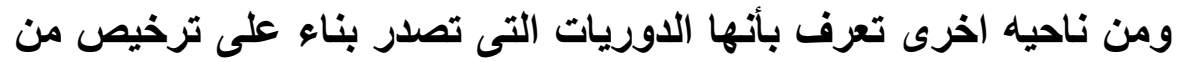

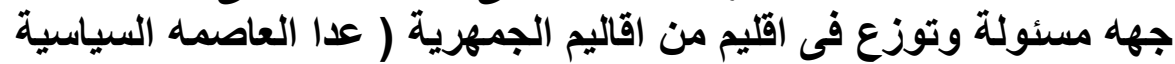

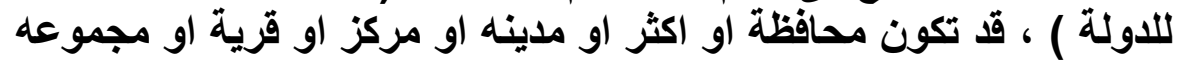

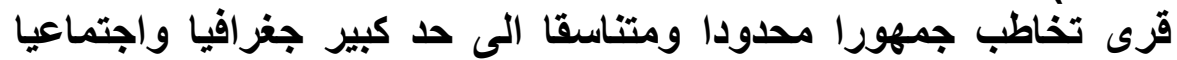

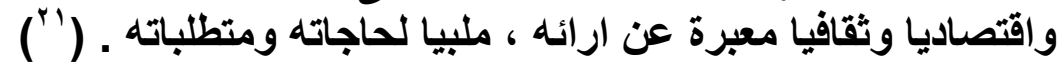

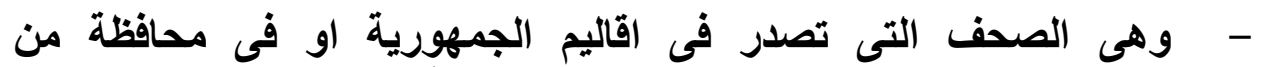

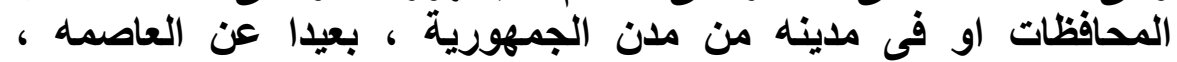

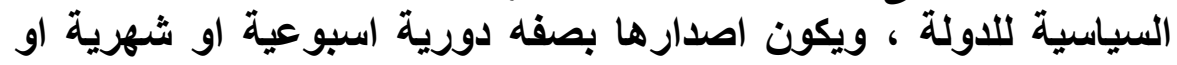

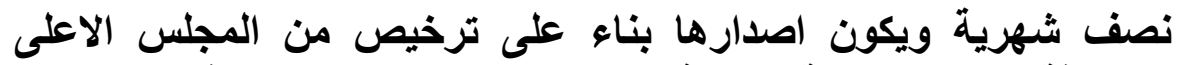

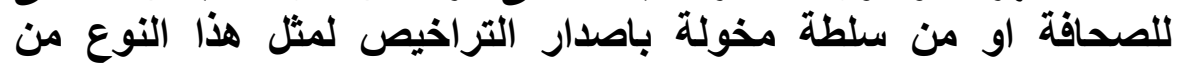
الصحف ، وتكون موجه لمخاطبة مواطنى الاقليم او المحافظة او المدئية المثله 
التى تصدر وتوزع فيها ، معبرة عن امال وطموحات واراء ومشاكل

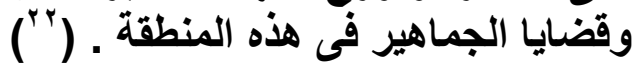

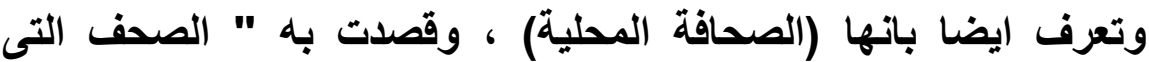

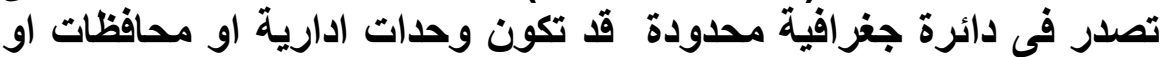

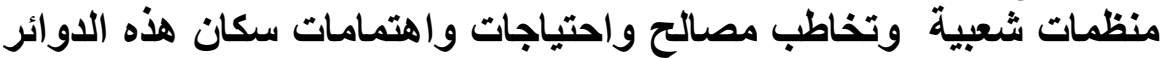
الجغرافية (")

ويرى اخر التى تصدر وتوزع فى نطاق المحافظات وتنثر الاخبار المتعلقة

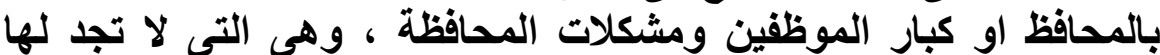

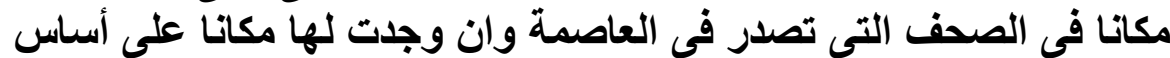

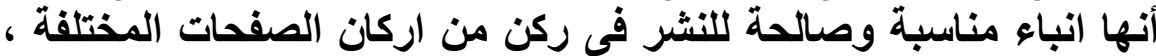

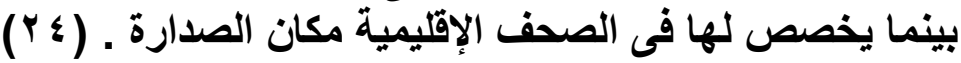

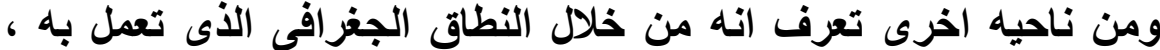

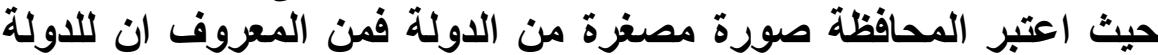

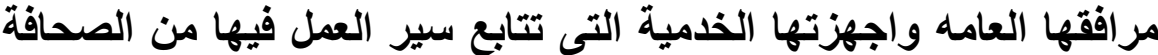

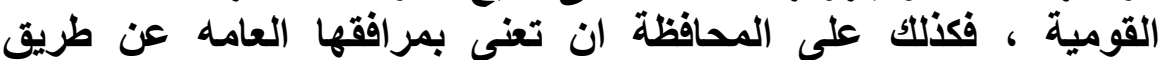

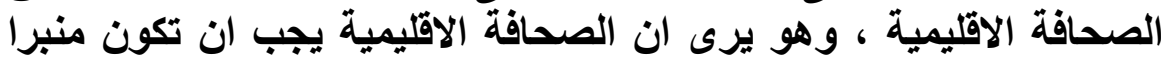

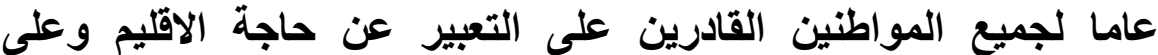

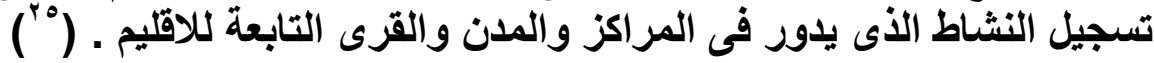

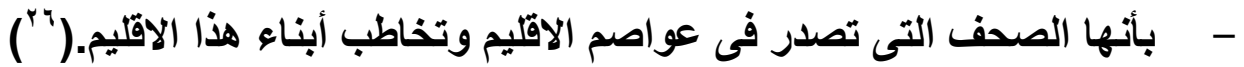

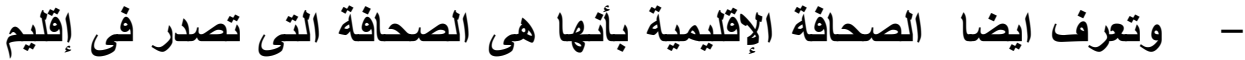

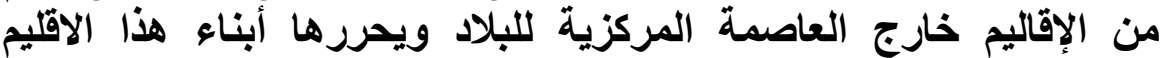

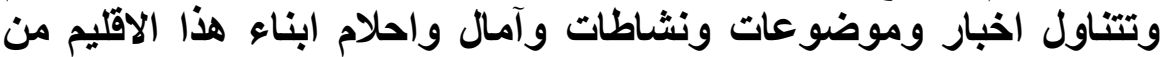

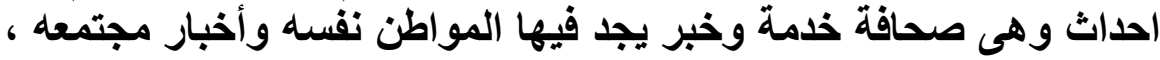

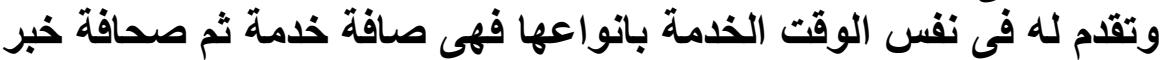

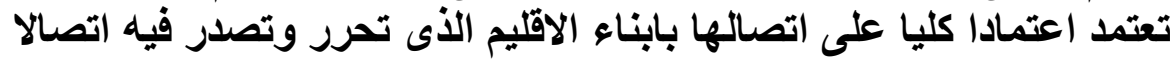

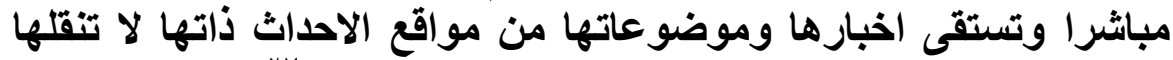

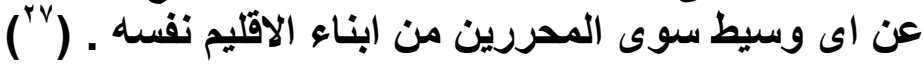

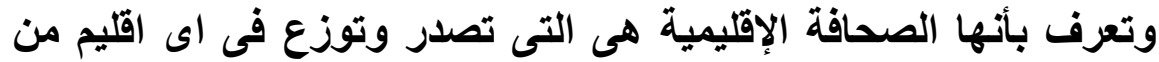

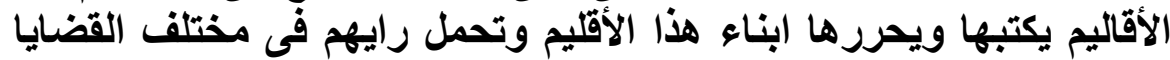

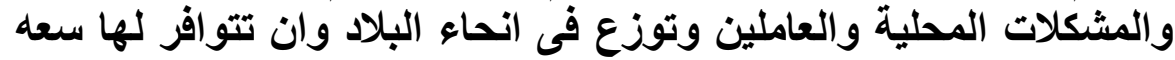

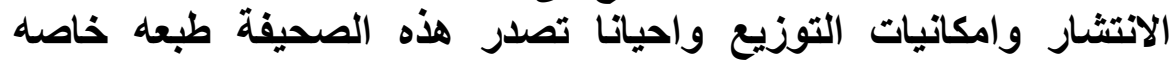

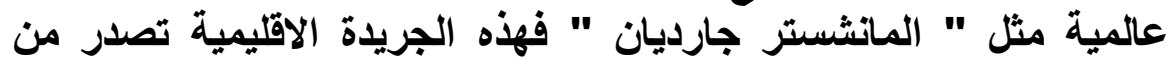
مانشتسر وليس من لندن ومع ذلك فلها تأثير كبير فى الراى الثيلة العام هن 
مجلة كلية الآداب، جامعة سوهاج، العدد الخمسون، الجزء الثاني، يناير 19 • ب م

الانجليزى لما تحمله من راى وفكر وتحليل لمختلف المشكلات السياسية

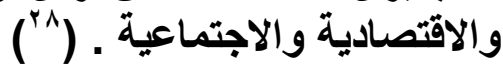

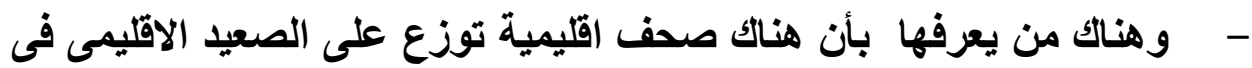

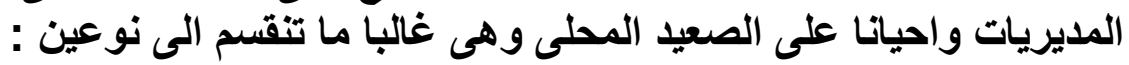

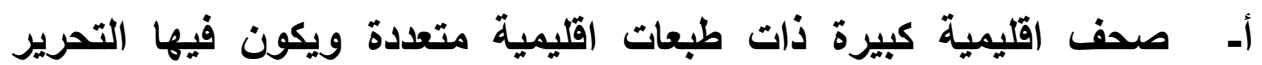

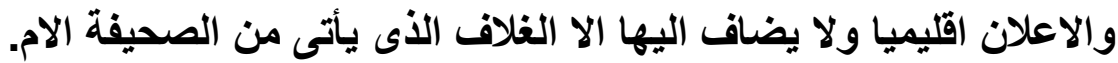

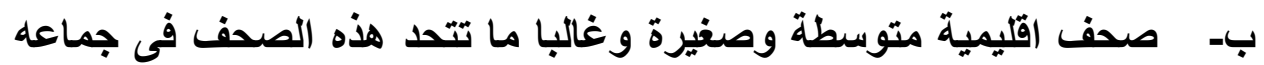

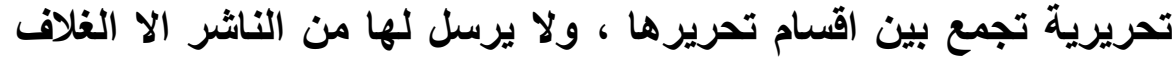

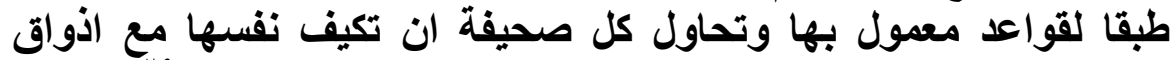

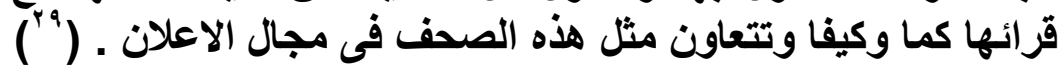

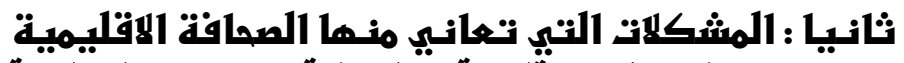

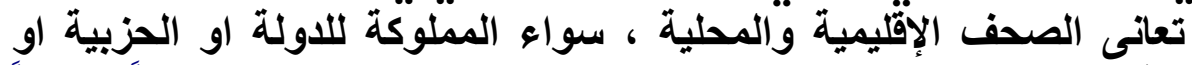

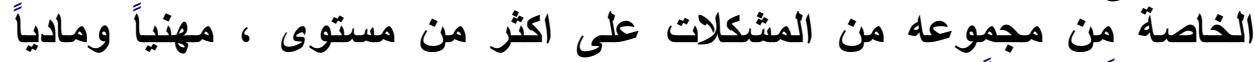

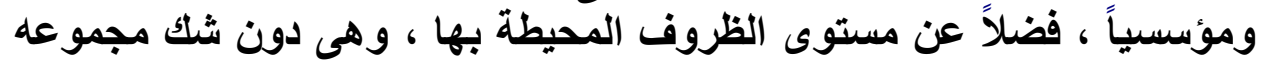

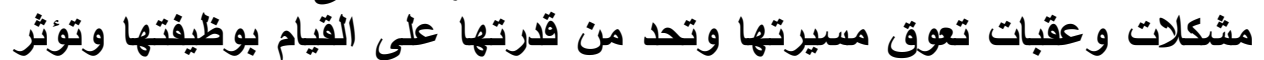

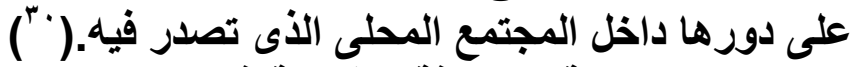

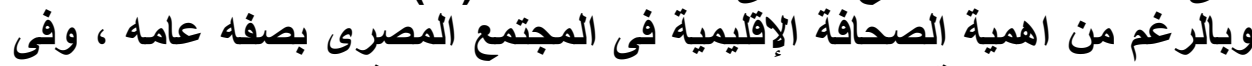

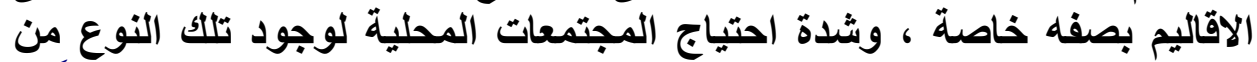

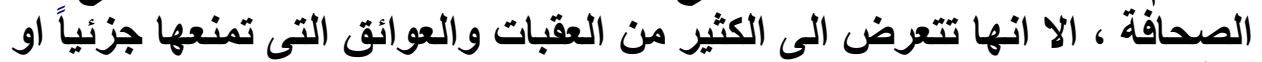

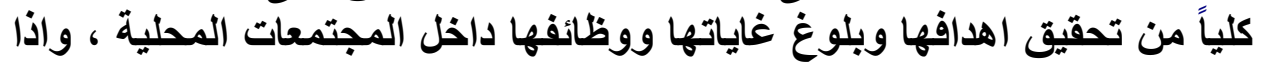

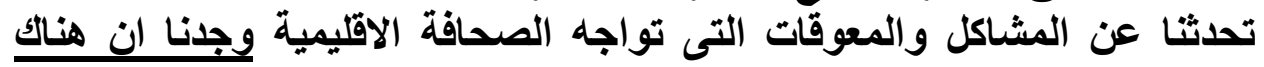

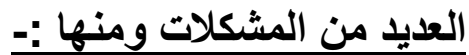

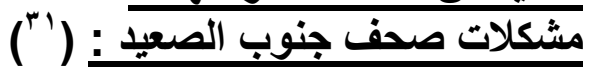

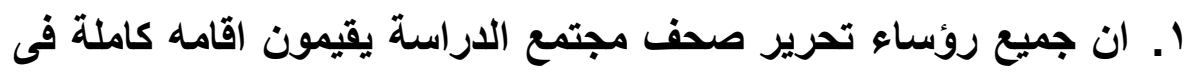

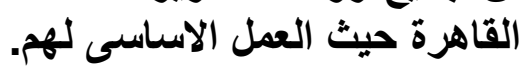

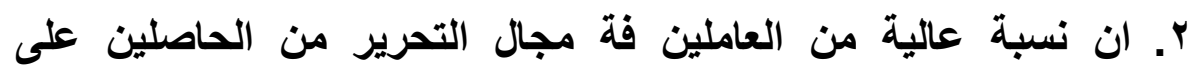

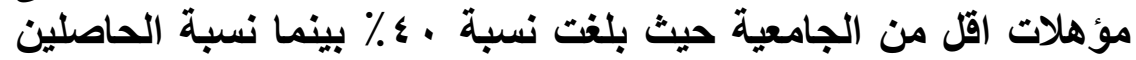

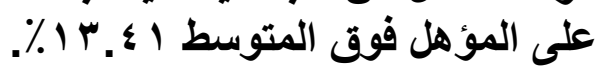

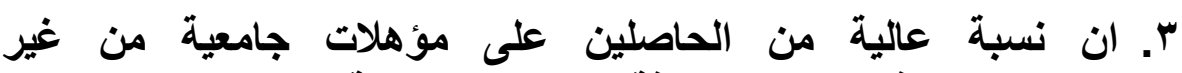

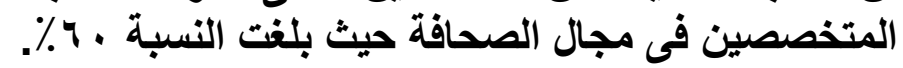

ع. ان مشاركة الاناث فى مجال التحرير فى صحف اقليم جنوب الصعيد 
ه. ان نسبة كبيرة من العاملين فى مجال التحرير فى صحف اقليم جنوب المبات

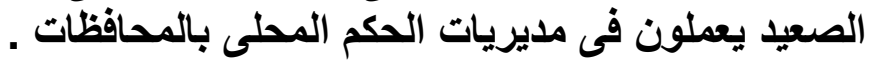

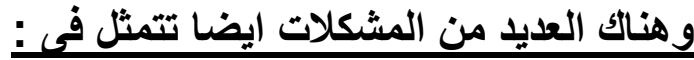
- مشكلة عدم وجود العدد الكافى من

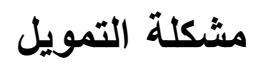
المحررين - - مشكلة علدم صدور الصحيفة فى ميعادها الثابت.

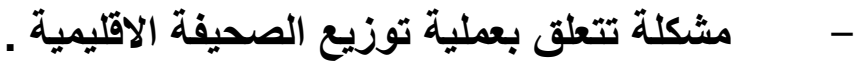

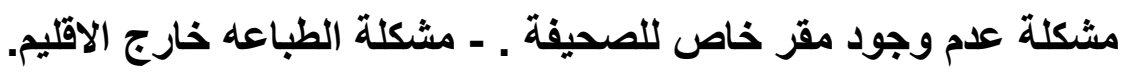

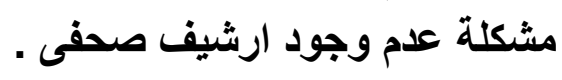

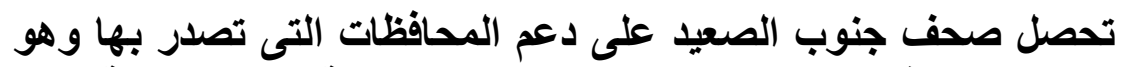

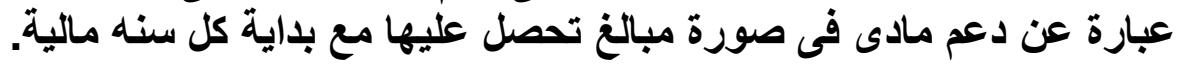

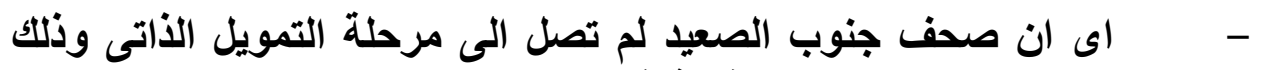
باعتمادها الكامل على مواردها الأتية فى التمويل ( الى من خلال التوزيع و وايراد

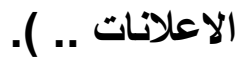

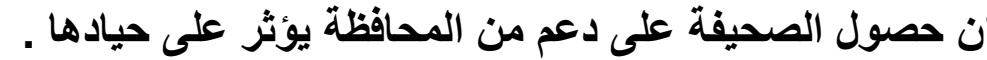

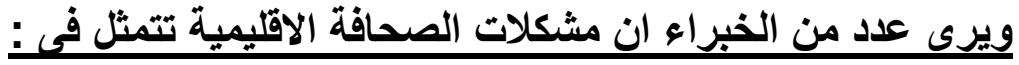

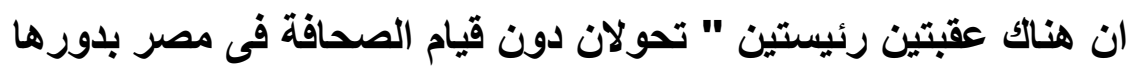

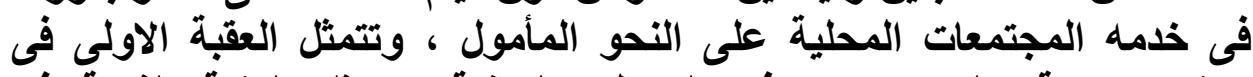

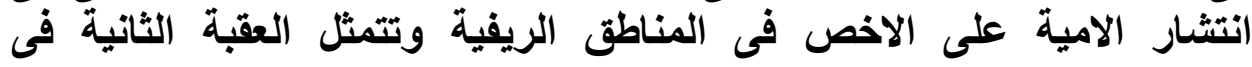

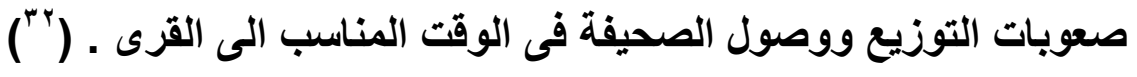

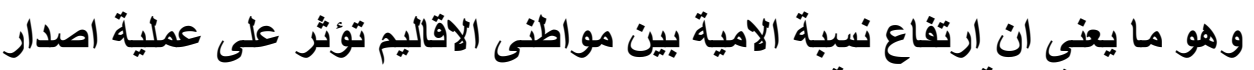

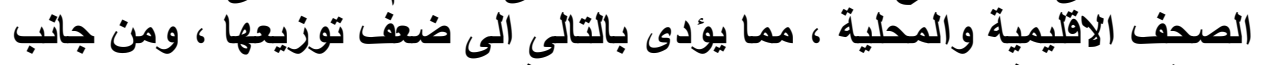
اخر فان صعوية التوزيع تعوق وصول الصحيفة الى القراء المتعلمين.

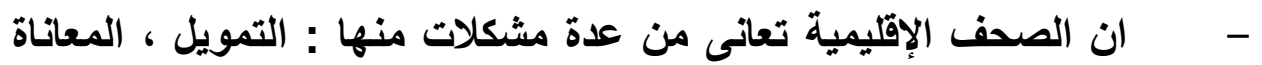

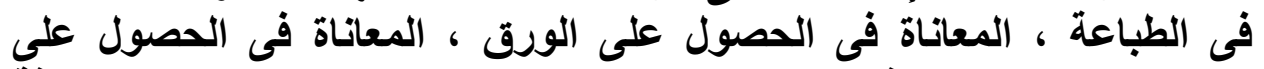

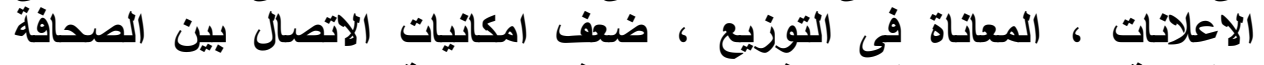

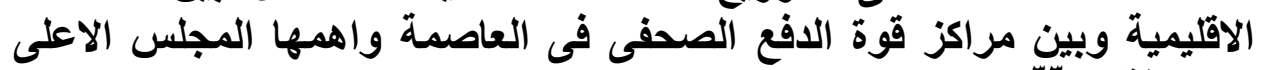

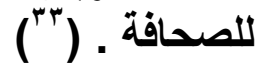


اجرث الباحثة مقابلة مع عينه من خبراء الاعلام باستخدام دليل المقابلة العلمية

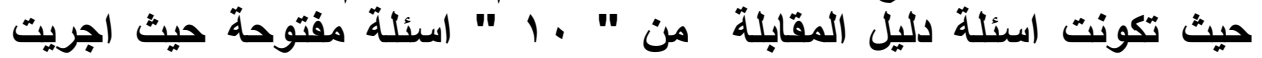

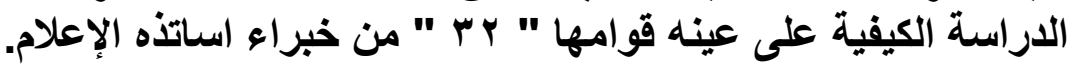

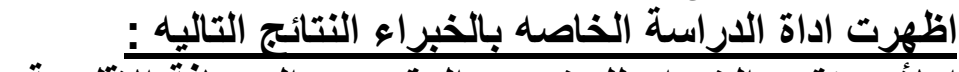

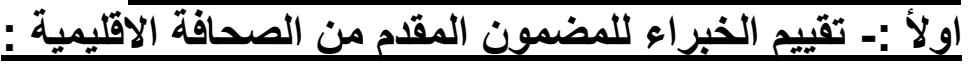

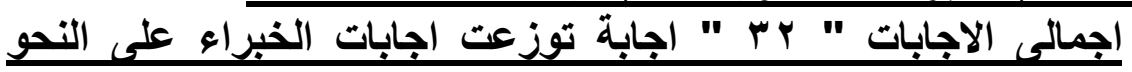

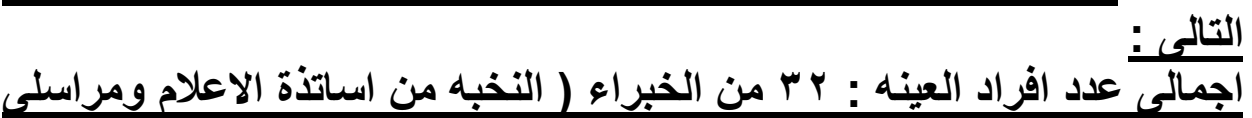

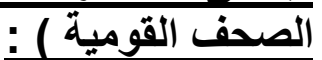

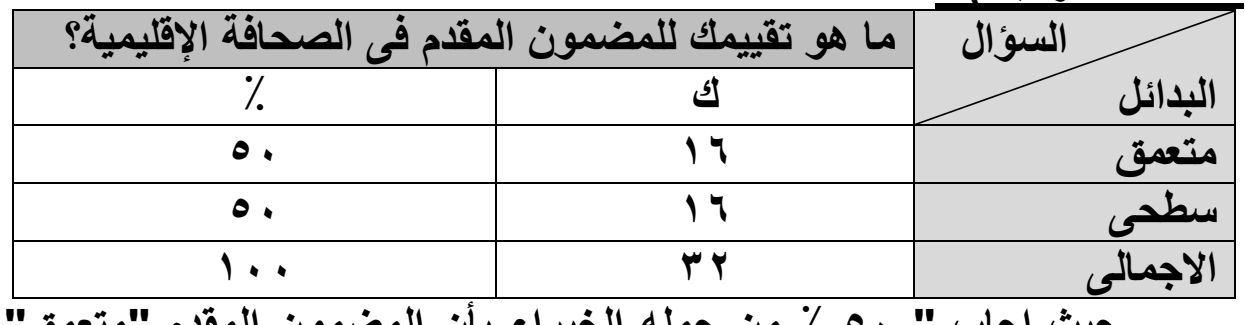

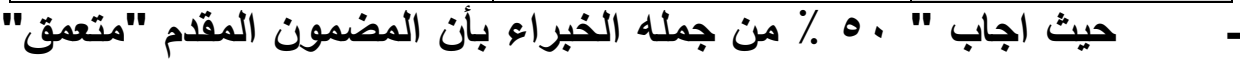

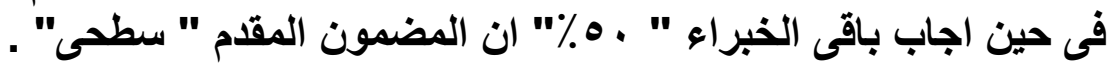

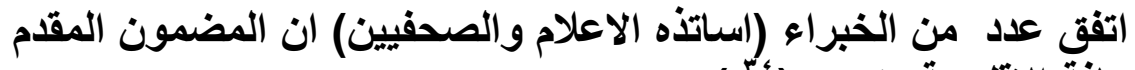

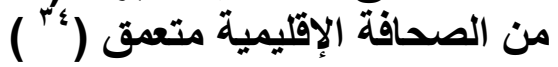

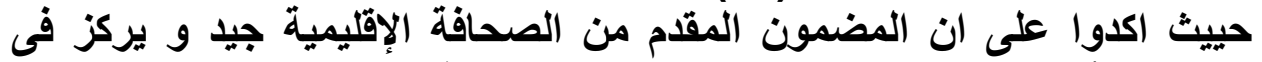

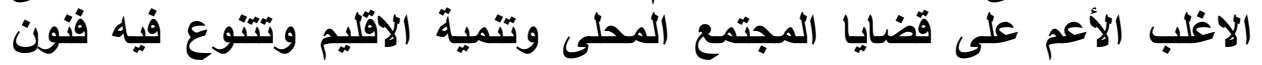

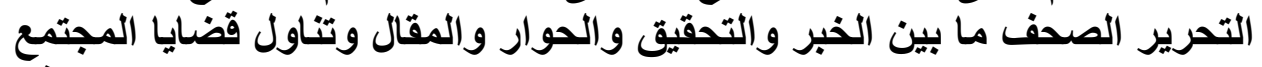

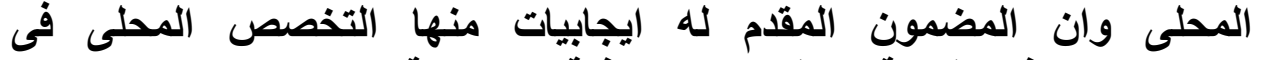

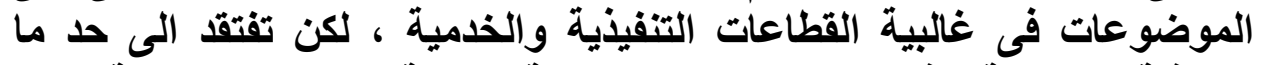

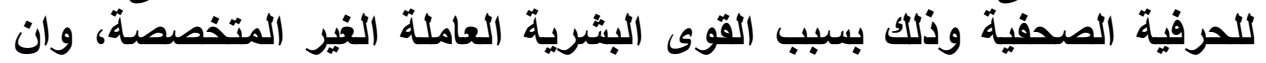

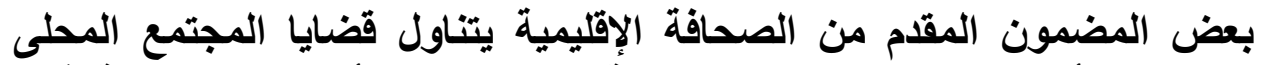

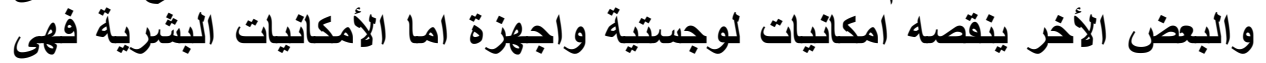

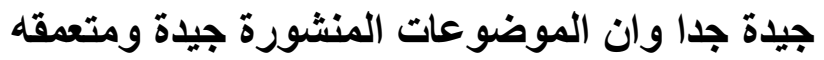

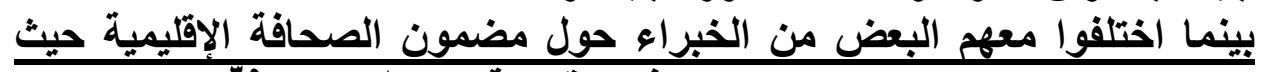

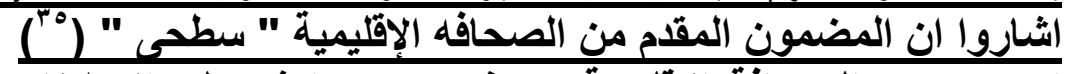

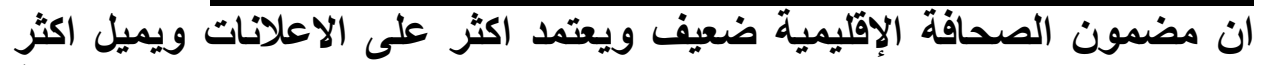

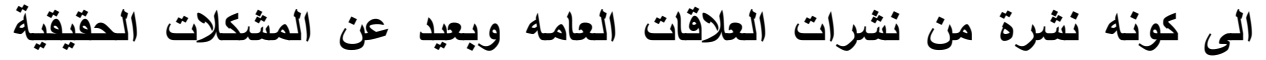

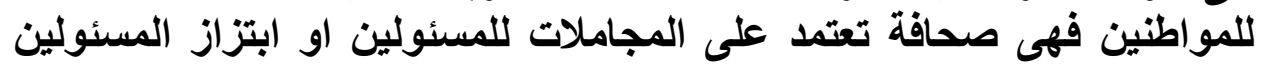

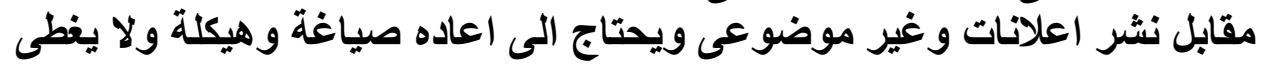




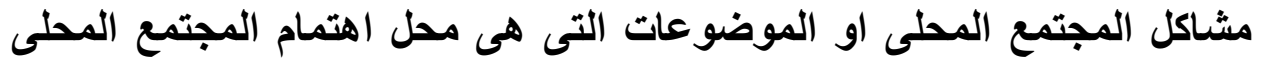

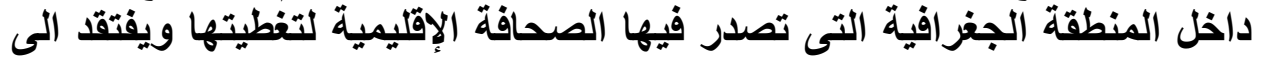

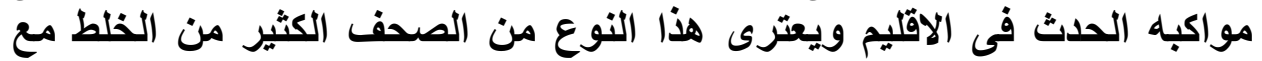

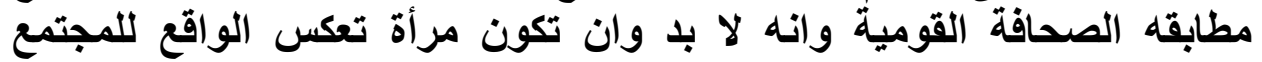

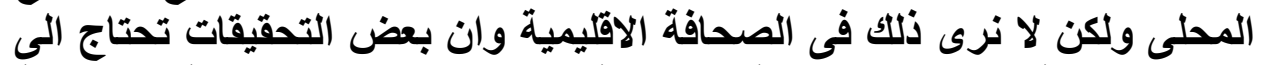

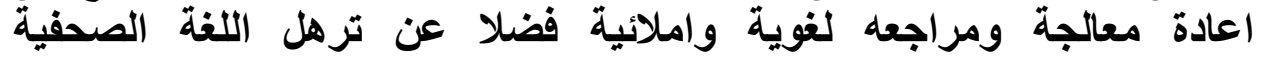

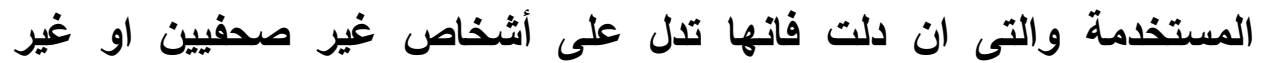

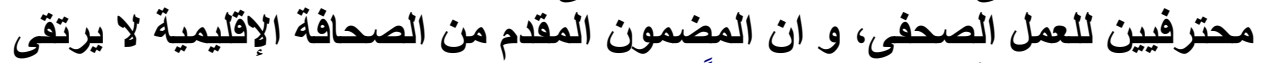

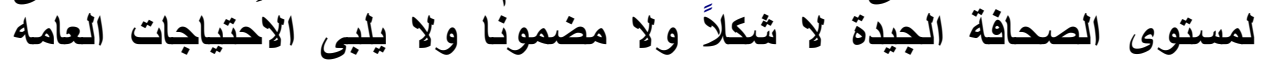

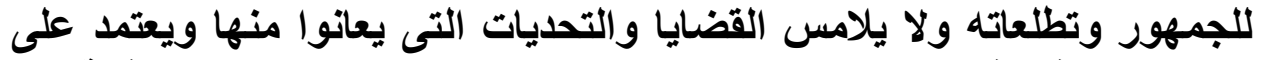
اخبار المحافظ فقط ولا توجد موضوعات تمس المواطن داخل المحافظة ولانا

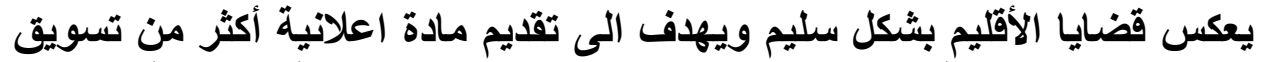

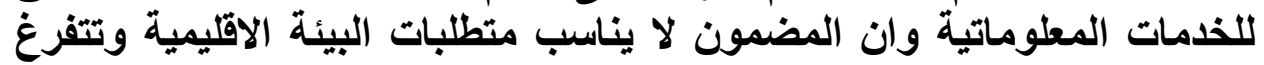

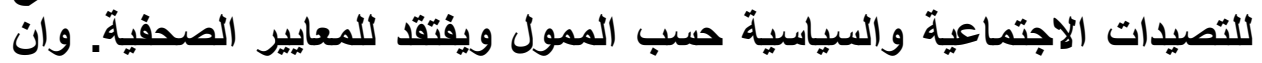

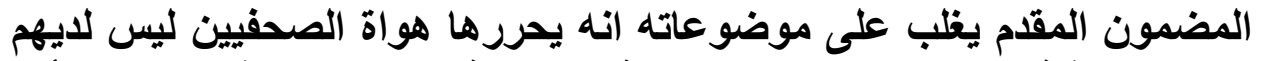

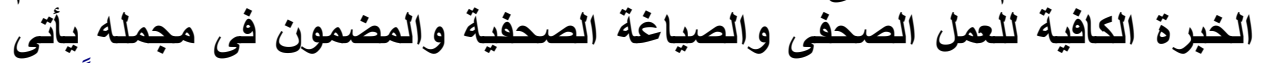

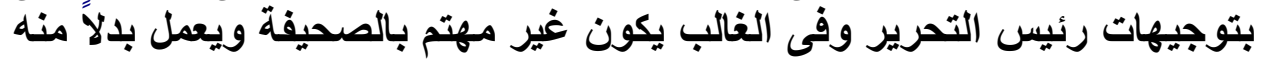

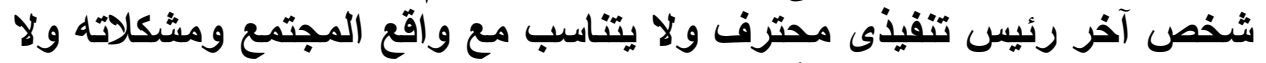

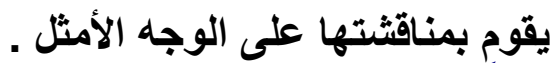

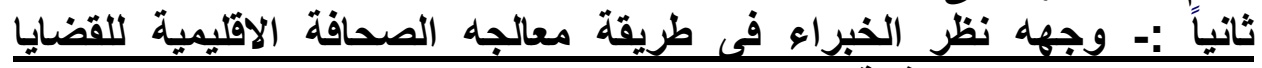

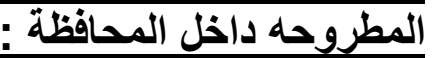

\begin{tabular}{|c|c|c|}
\hline \multicolumn{2}{|c|}{ 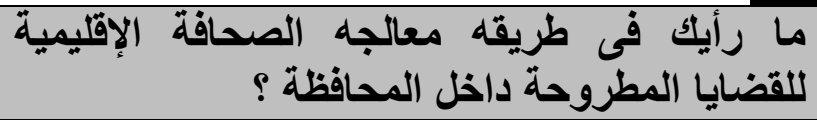 } & البدائل السؤال \\
\hline $1 \wedge . \vee 0$ & 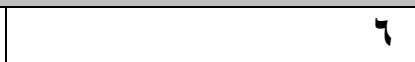 & متعمقة \\
\hline$r \varepsilon . \varepsilon$ & 11 & سطحية \\
\hline 11.80 & 7 & غير متوازنـه \\
\hline$r q$ & 9 & ناقصه \\
\hline $1 \ldots$ & rr & الاجمالى \\
\hline
\end{tabular}

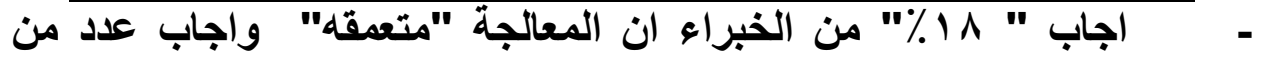

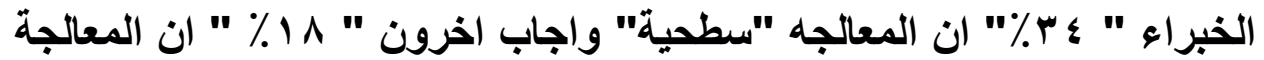

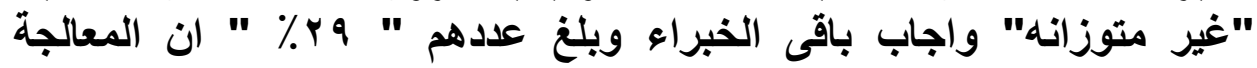


مجلة كلية الآداب، جامعة سوهاج، العدد الخمسون، الجزء الثاني، يناير 9 1 ـ بم

وضح عدد من الخبراء من اساتذه الاعلام ان معالجة الصحافة الإقليمية

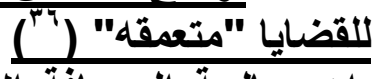
ان معالجة الصحافة الاقليمية للقضايا المطروحة داخل محافظتهم متعمقه من الصناه

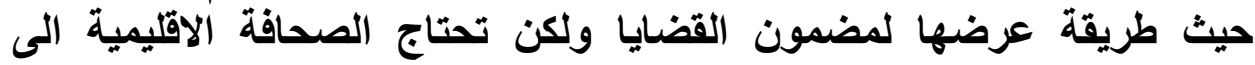

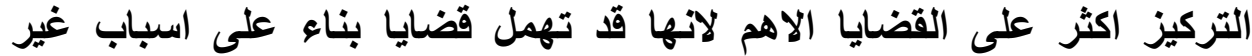

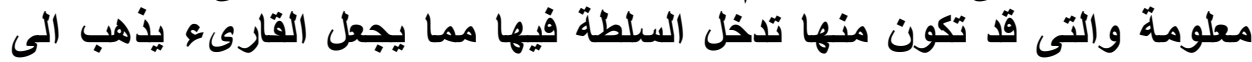

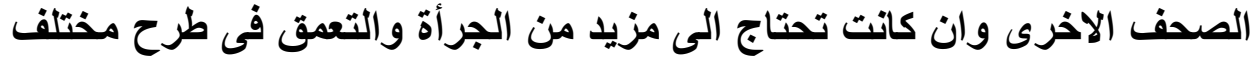

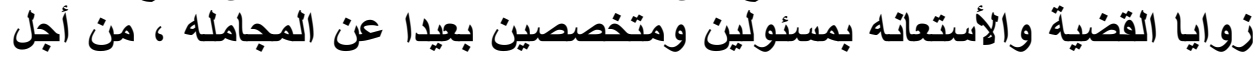

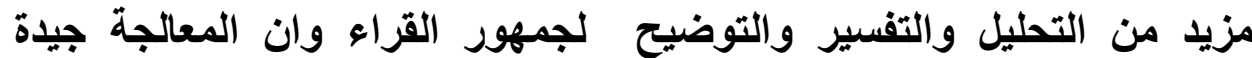

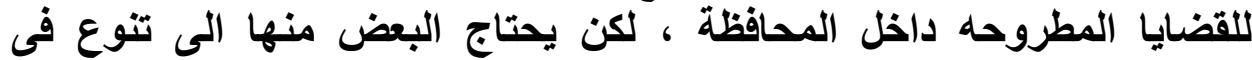

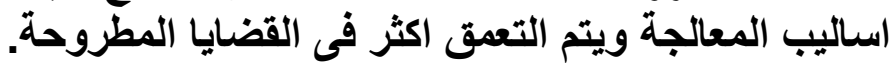

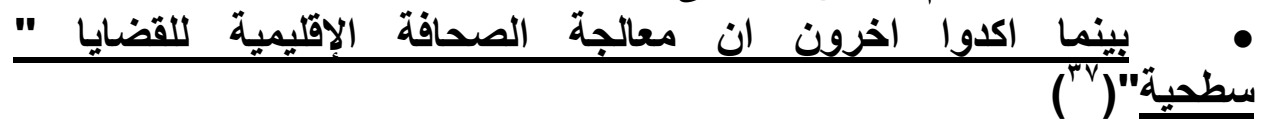

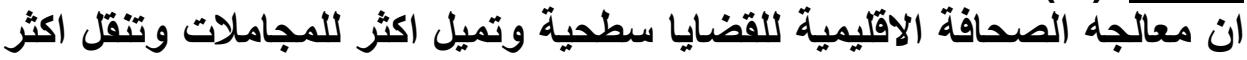

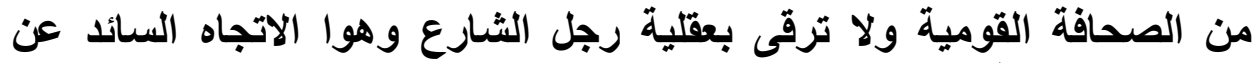

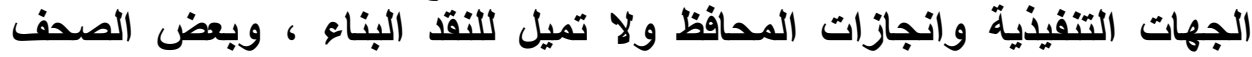

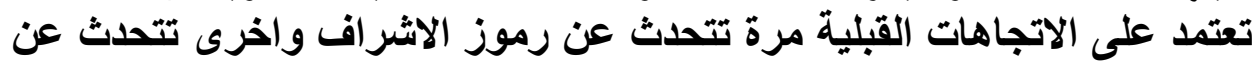

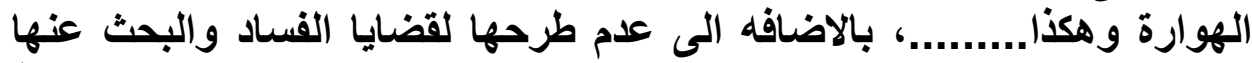

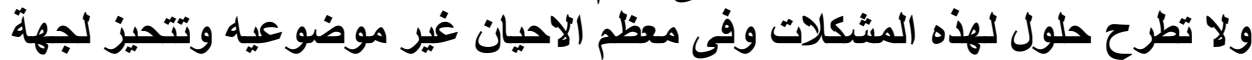
ما غير معينه. • ميث اشثار عدد من الخبراء ان المعالجة المقدمة من الصحافة الاقليمية

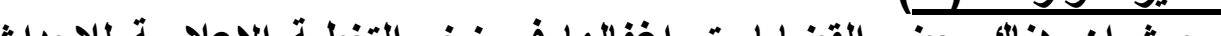

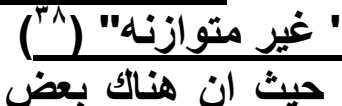

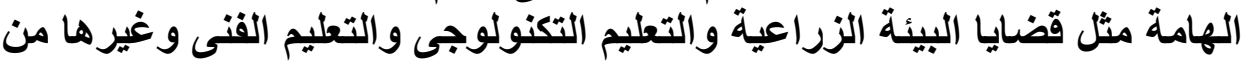

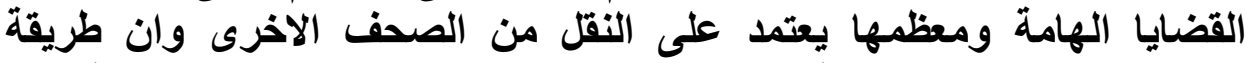

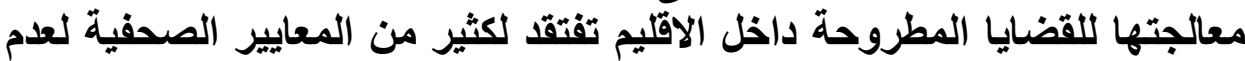

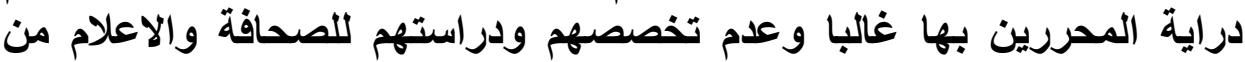

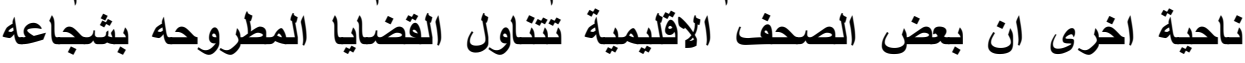

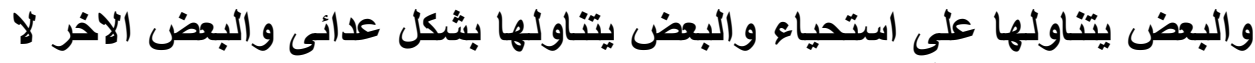
يتناولها من بعيد او قريب.

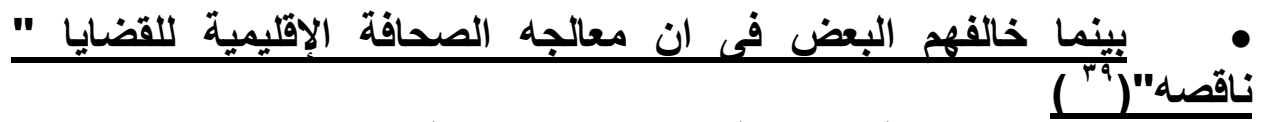

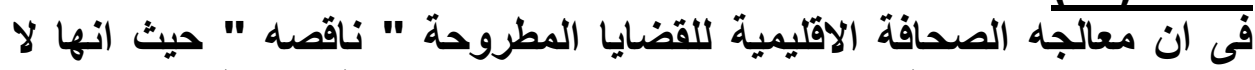

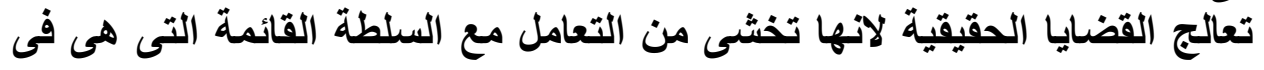




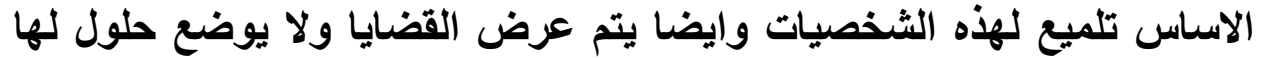

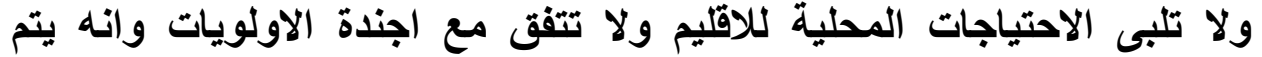

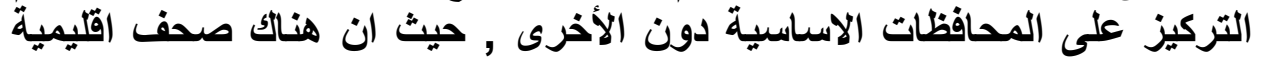

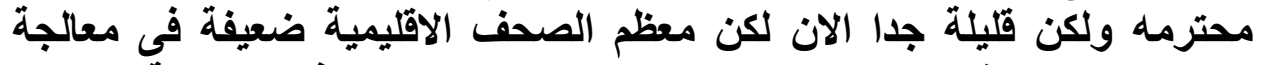

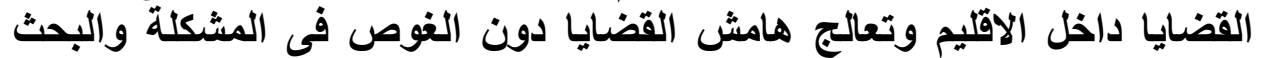

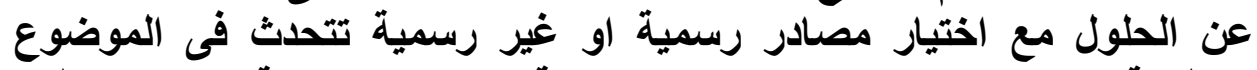
بسطية شديدة وعدم التوجه للمصادر الهامة ، كما ان ان معالجة القضايا تتطلب

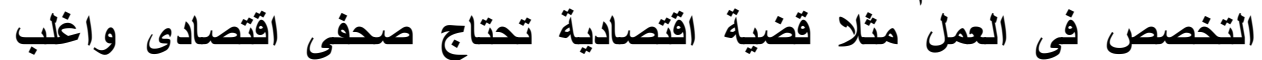

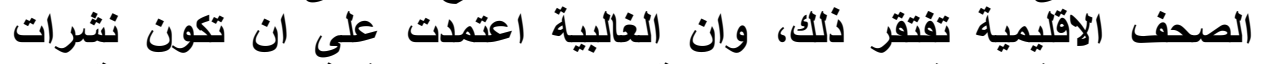

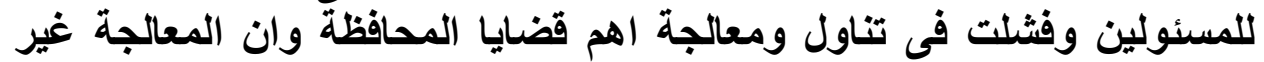

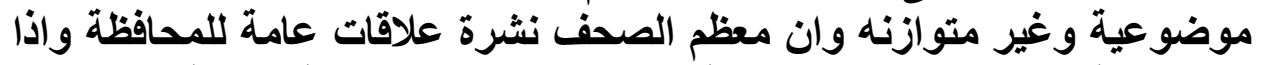

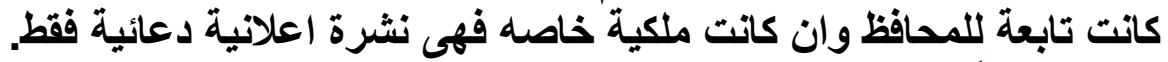

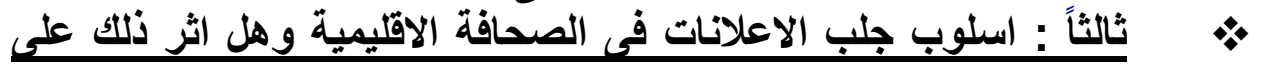

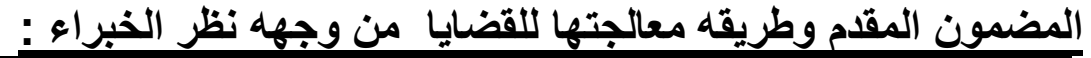

\begin{tabular}{|c|c|c|}
\hline \multicolumn{2}{|c|}{ 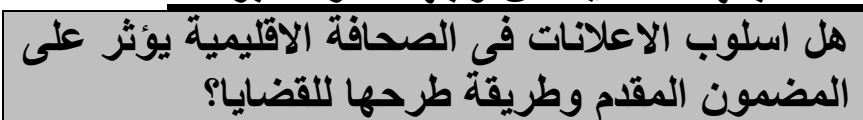 } & \multirow[t]{2}{*}{ السؤال } \\
\hline$\%$ & ك) & \\
\hline $9 . .740$ & $r q$ & 'نعم \\
\hline 9. rVo & $r$ & $y$ \\
\hline $1 \ldots$ & $M r$ & الاجمالى \\
\hline
\end{tabular}

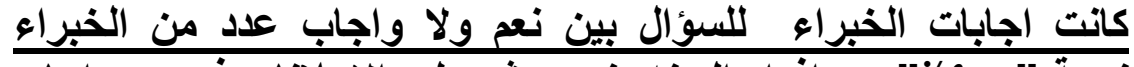

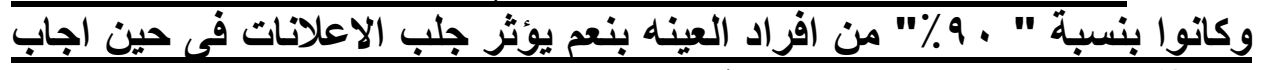

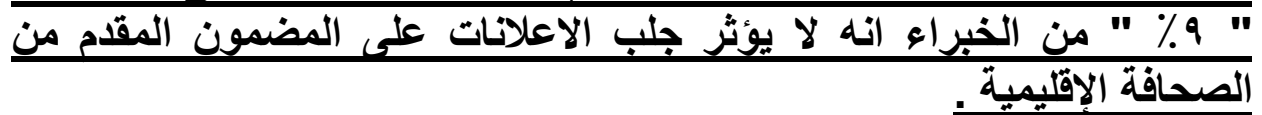
- المضح الإيمية مند من الخبراء ان سلوب جلب الاعلانات اثر على المضمون

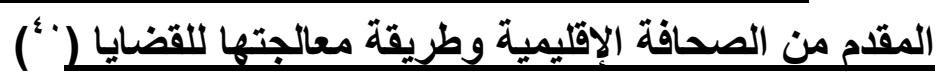

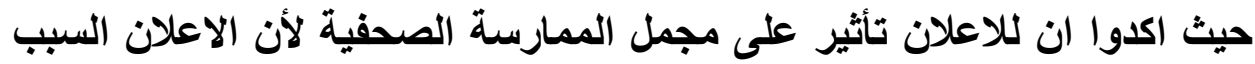

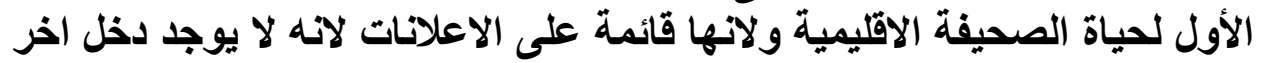

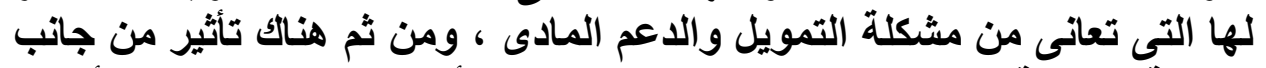

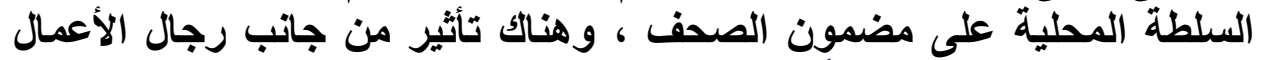

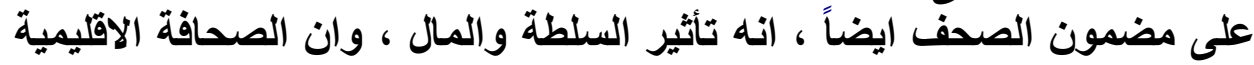

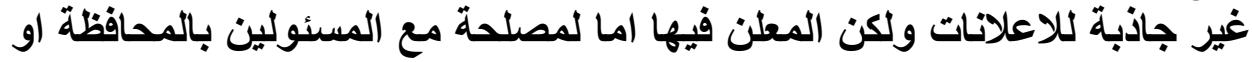

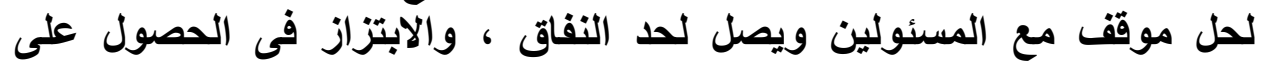
الاعلانات مقابل نشر موضوعات معينه للجهات المموله وتكون الموضوعات 
مجلة كلية الآداب، جامعة سوهاج، العدد الخمسون، الجزء الثاني، يناير 9 1 • بم

المنشورة بعيدة عن الموضوعية وعدم وجود معايير ، وهذا ادى الى عدم انتظام العديد من الصحف فى الصدور ، وخاصه ان بعض المعلنين ايديهم غير فير بيضاء

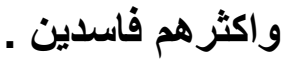

بينما اختلفوا معهو عدد من الخبراء ان اسلوب جلب الاعلانات لا يؤثر

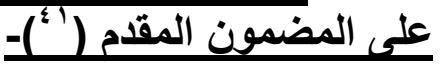

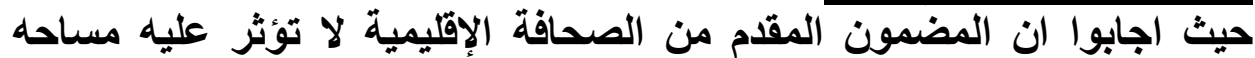

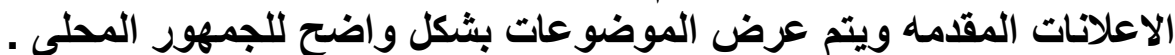

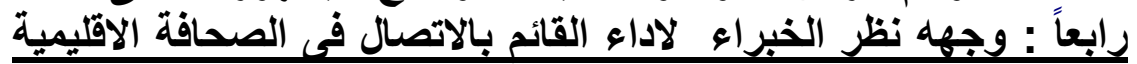

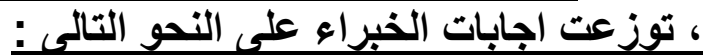

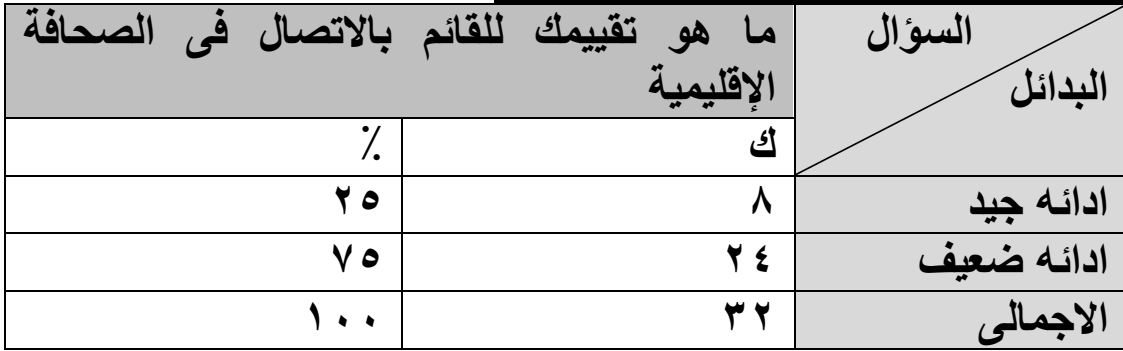

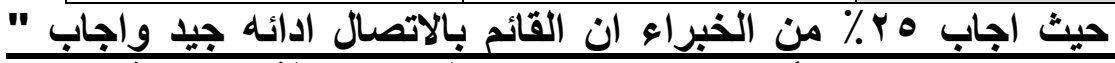

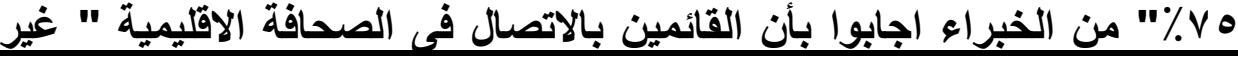

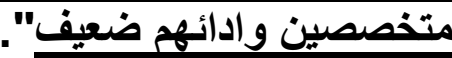
اكد عدد من الخبراء ان اديف" اداء القائم بالاتصال فحى الصحافة الاقليمية ادائه (ي) ان القائم بالاتصال فى الصحافة الإقليمية ادائه جيا ومجتهر وعلى مستوى عالًَ

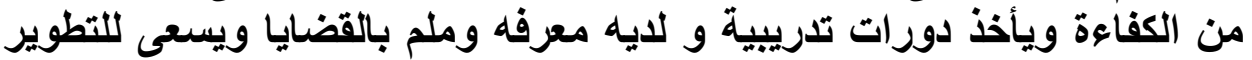

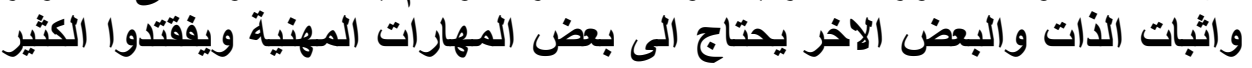

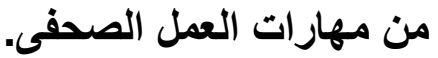

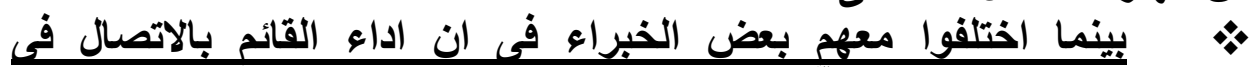

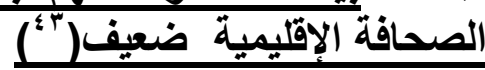

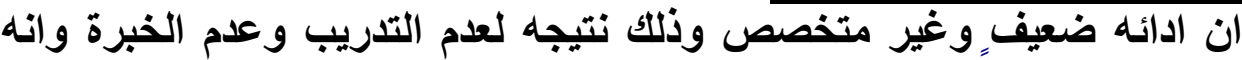

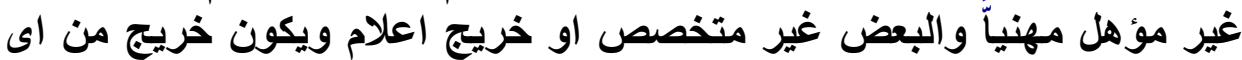

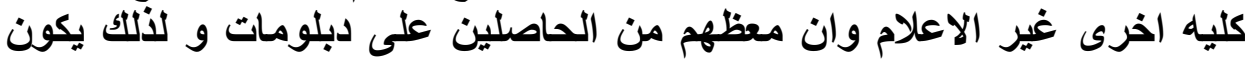

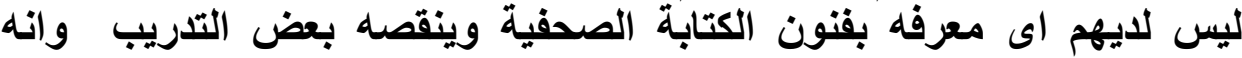

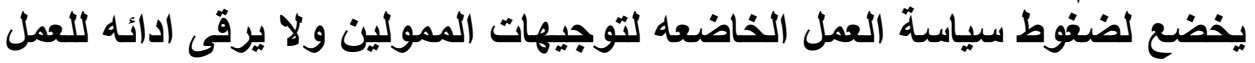

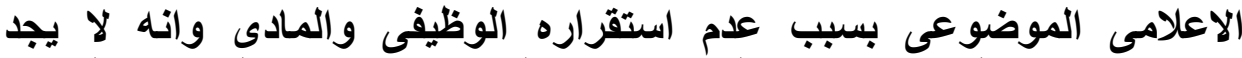
الامكانيات الكافية لاقامه صحافة جادة والبنية التحتيه للصحيفة الاقليمية غير واله 
اتجاهات جمهور الخبراء نحو الصحافة الإقليمية في صعيد مصر .. دراسة ميدانية

مكتمله والتكنولوجيا المستخدمة لانتاجها ضعيفه والمرتبات ضعيفة او احيانا

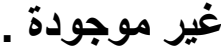

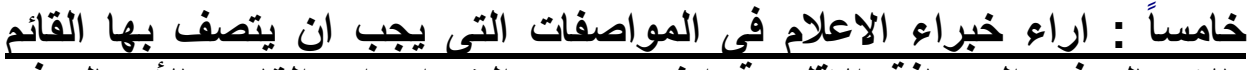

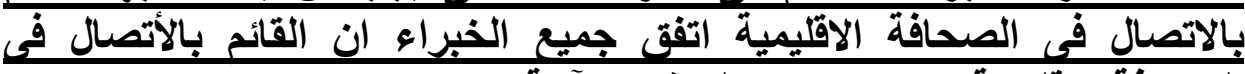

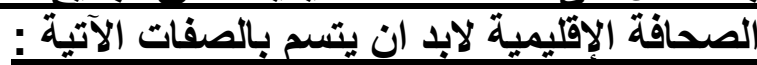

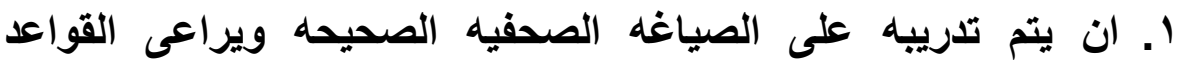
النحوية والأملائية فضلا عن الاخية الاخراج الصحفى.

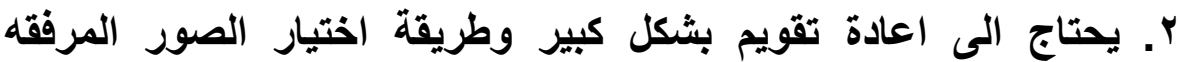

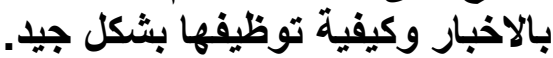

r. لابد ان يكون من ابناء الاقليم حتى يشعر بقضاياهم ومشكلاته لكى يطرح الحلول لـها.

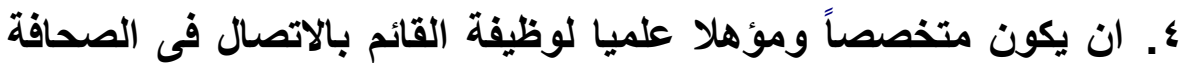
والاعلام ومتدربا وليس من حمله الابلومات الفيات هلية .

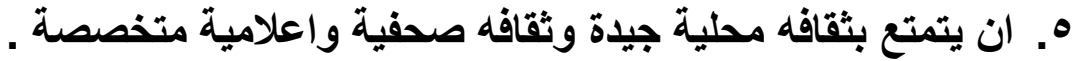

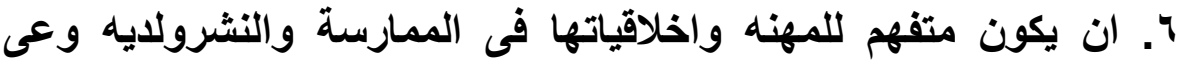

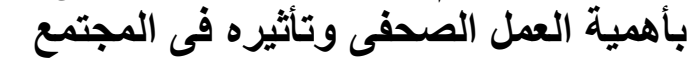
V. لابد ان يحصل على بكالوريوس اعلام اولاً ويؤهل نفسه بالأورات

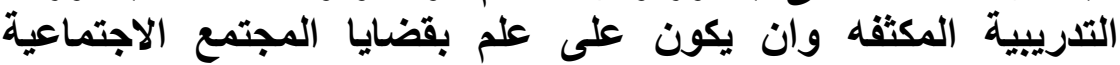
والثقافية ....... و هكذا. ^. الالمام بالتقنيات الحديثة ووسائل الاتصال والتكنولوجيا .

* مادساً : وجهه نظر الخبراء لاور الصحافة الاقليمية في تنمية المجتمع

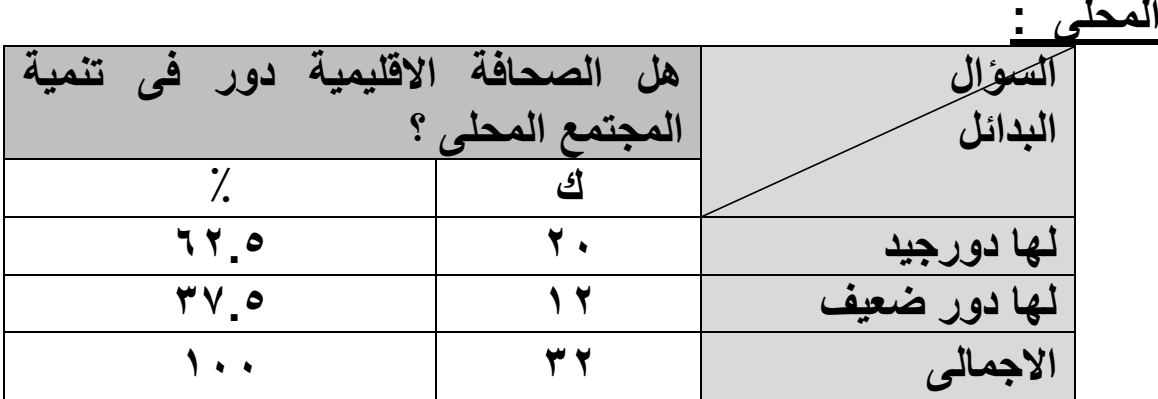

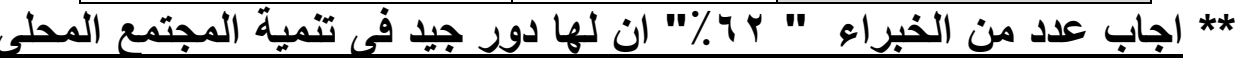

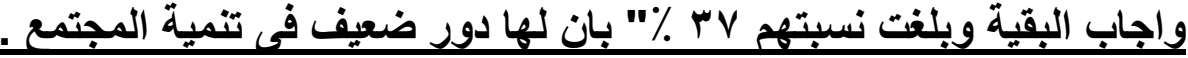

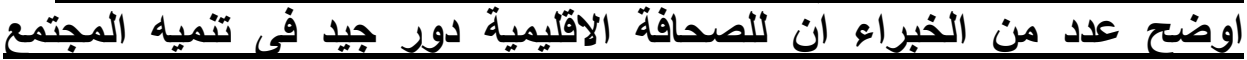
المحلى) (2) 
فهى تناقش القضايا المحلية وتقدم الحلول وتثقل شكاوى المواطنين وافكارهم

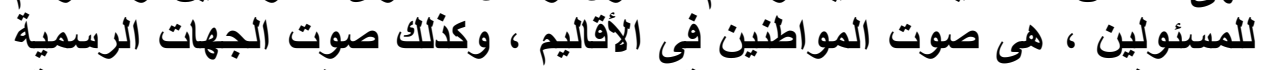

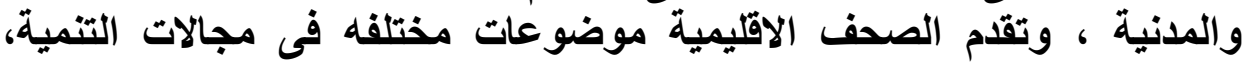

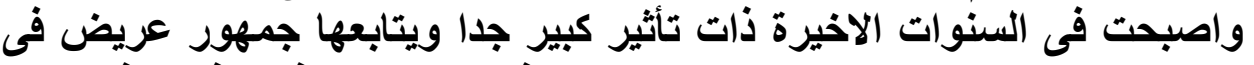

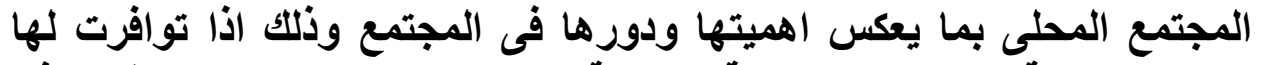

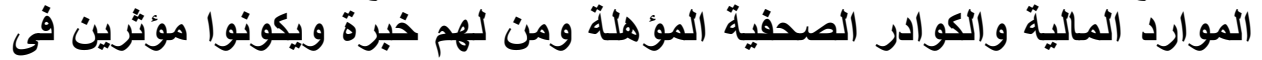

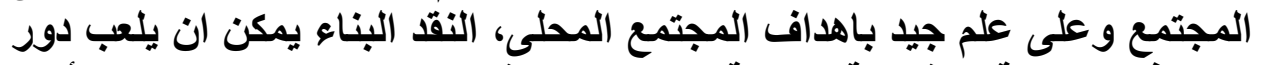

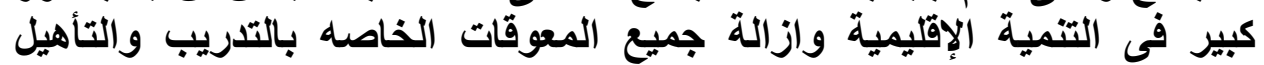

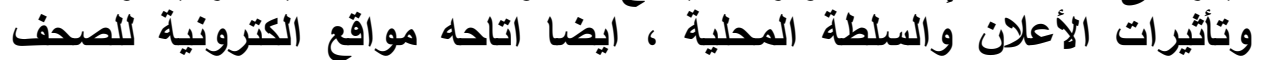
الاقليمية التى تصدر داخل الأل والمان المحافظات.

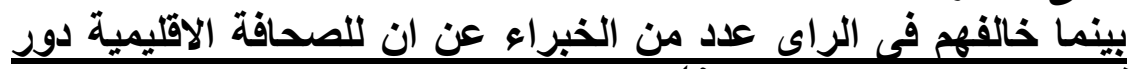

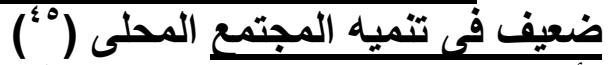

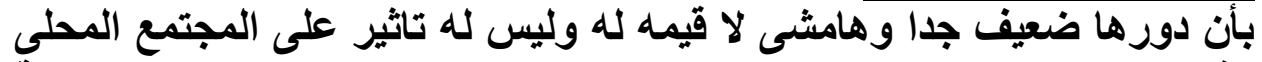

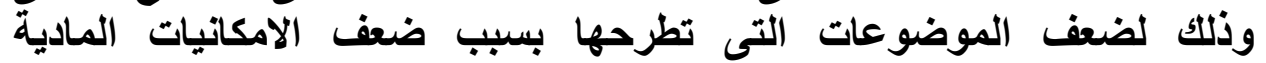

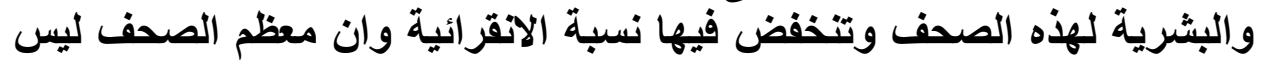

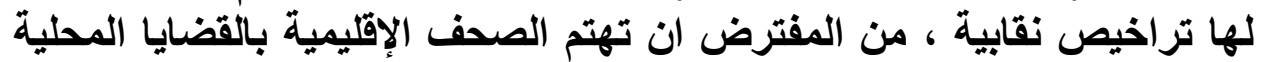

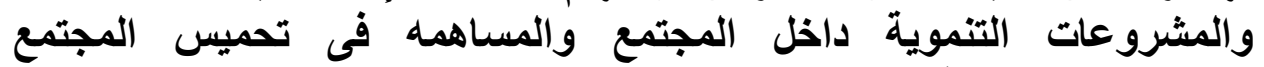
ل للمشروعات الناجحة .

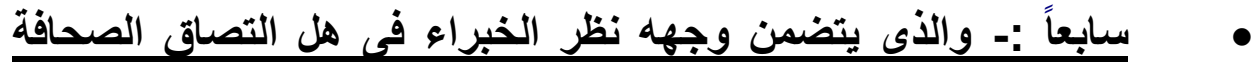

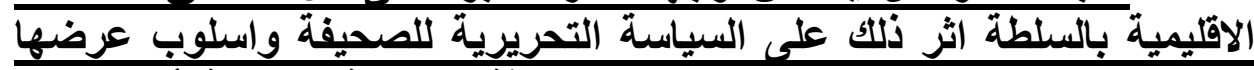

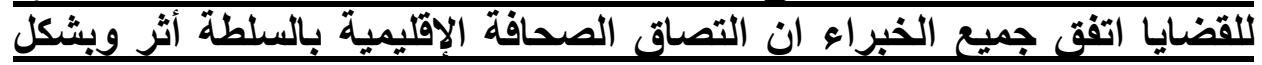

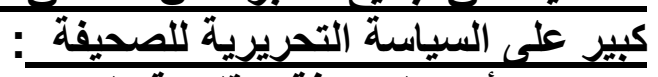

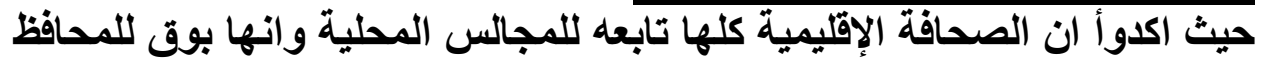

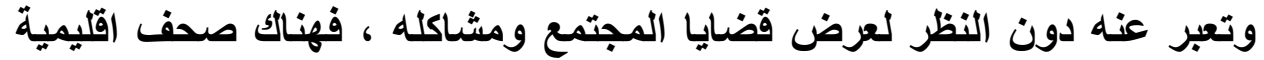

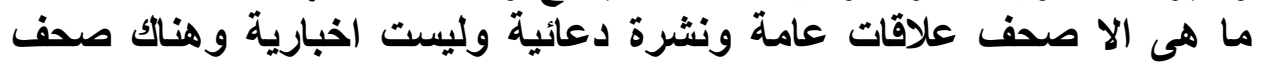

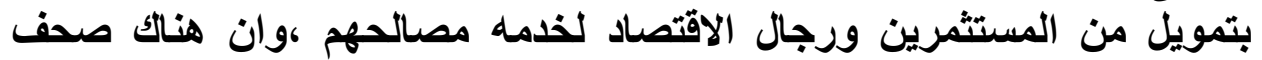

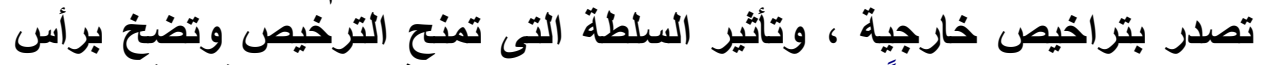

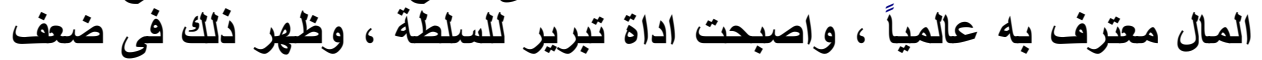

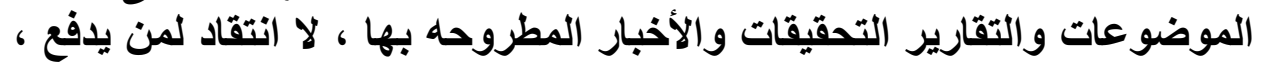

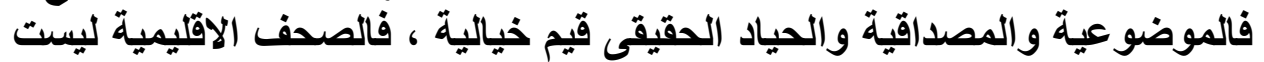

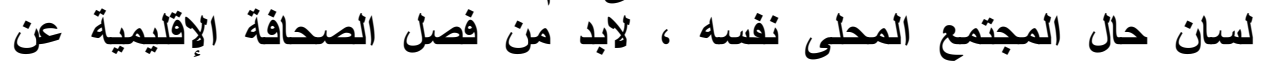

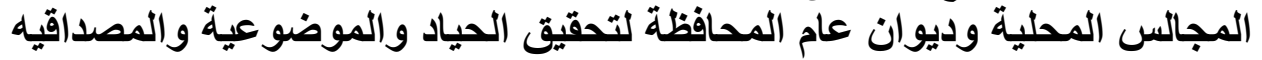

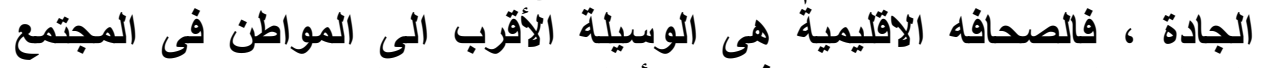

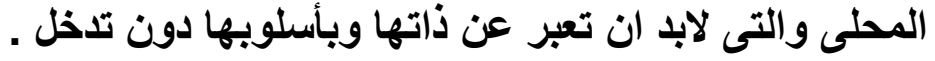


اتجاهات جمهور الخبراء نحو الصحافة الإقليمية في صعيد مصر .. دراسة ميدانية

ثامناً : والأى يتضمن وجهه نظر الخبراء فحى هل الصحافة الاقليمية تعرض

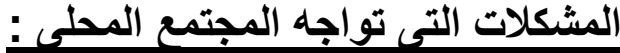

\begin{tabular}{|c|c|c|}
\hline \% تعرض المشكلات التى & تو & آلهويؤال \\
\hline IY.O & $r$. & نعم \\
\hline$r V_{.0}$ & IY & $\gamma$ \\
\hline $1 \ldots$ & $r r$ & الاجمالى \\
\hline
\end{tabular}

اجاب "r 7\%" من الخبراء بـ " نعم " تعرض المشكلات التى تواجه

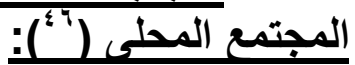

حيث اوضحوا ان الصحافة الإقليمية تعرض مشكلات المجتمع المحلى وبنسبة كبيرة تعالج وتلقى الضوء على المشكلات الموجودة بالإقليم المحلى ، لكن الأهم الماته

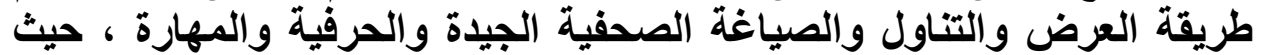

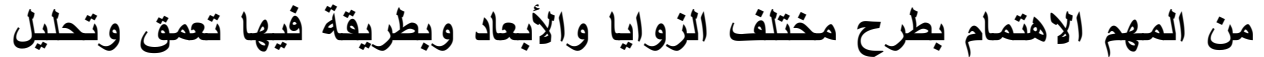

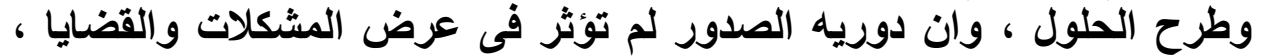

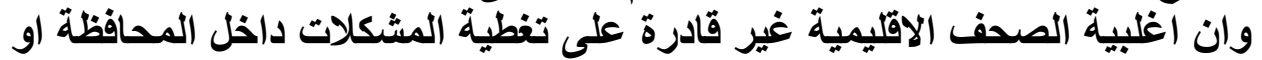
الأقليم ككل ولحساسية بعض القضائ القضايا والتأثيرات السياسية ورأس المال

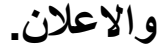

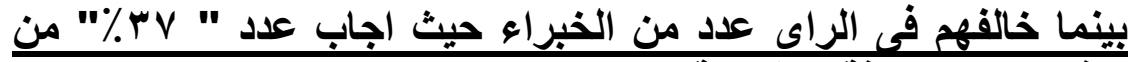

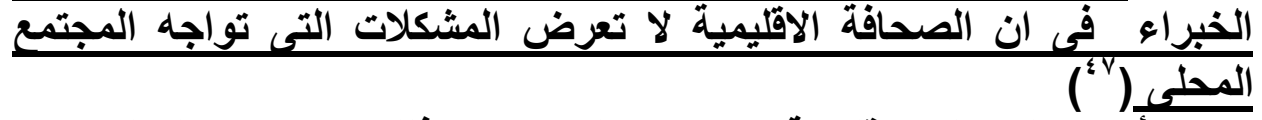
حيث رأو ان الصحف الاقليمية لا تعرض المشكلات وذللك انها بعيدة كل البعد عن

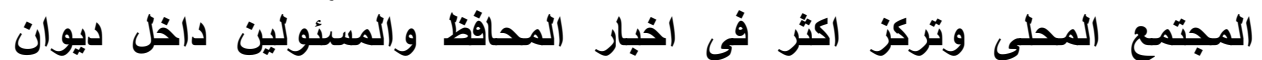

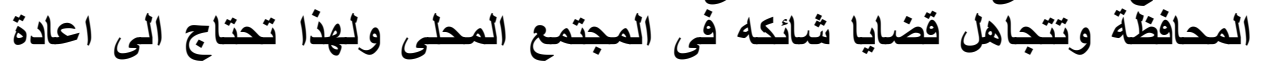

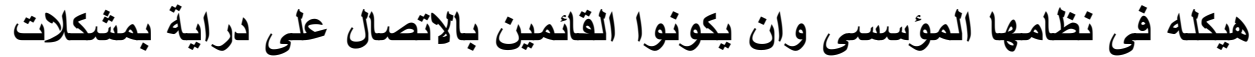

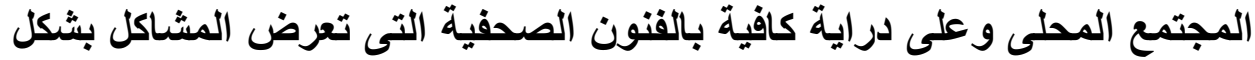
جيد ومفهوم للمواطن المحلى المعل درائ

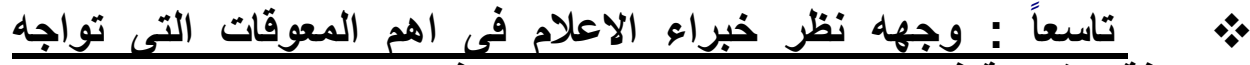

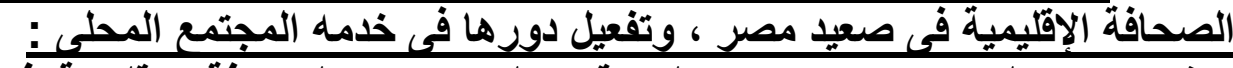

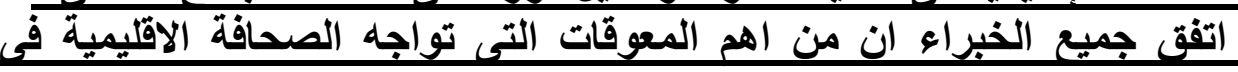

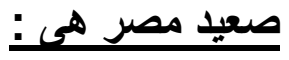

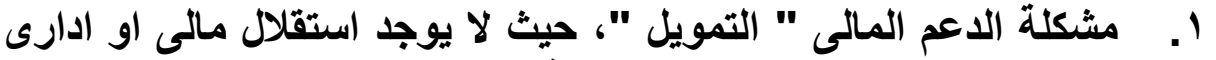
مما يؤثر على انتظام صدور الصحيفة بشكل دورى ومنتظم. 


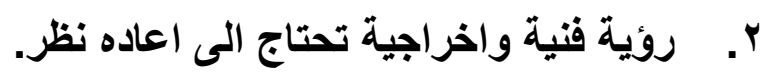

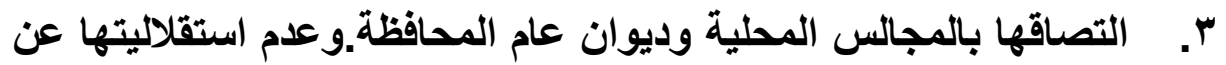

السلطة وهوا ما ينتج عنه ضعف المضمون.

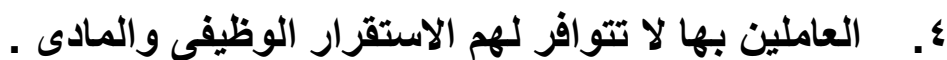

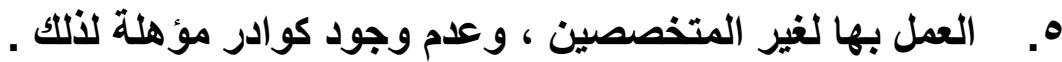

7. ليس هنالك وعى كاف فى الدولة لأهمية الصحافة الإقليمية .

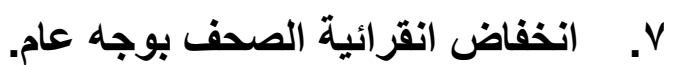

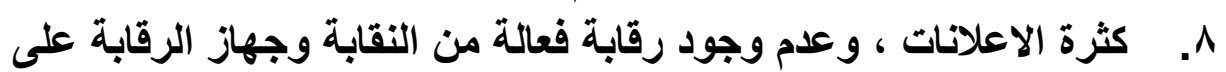

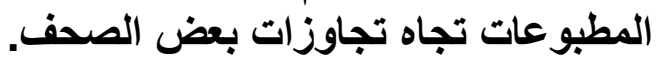

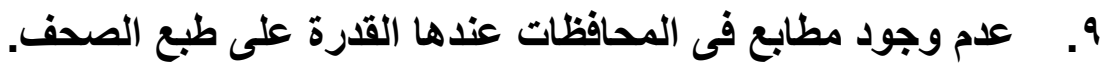

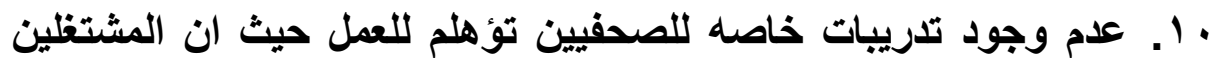

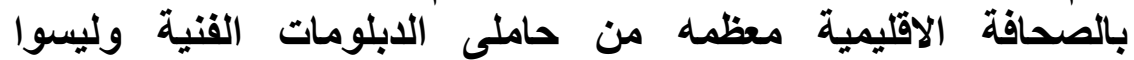

متخصصين.

11 ـ ـ عدم توفر الأجهزة التكنولوجية الحديثة داخل الصحف .

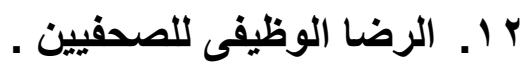

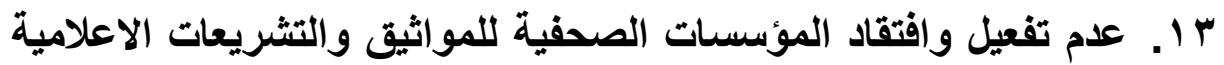
التى تنظم العمل داخل الصحيفة.

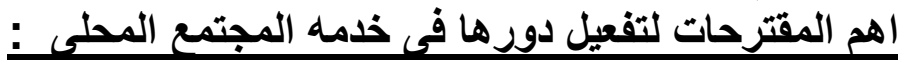

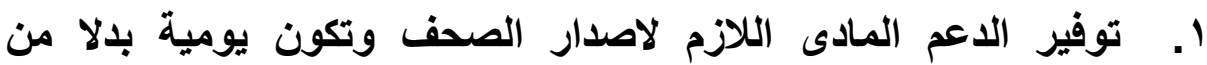
شهرية او سنوية. r. تأهيل الشباب وتدريبهم على قواعد الفنون الصحفية والأخراج الجيد للصحيفة . لأهيل

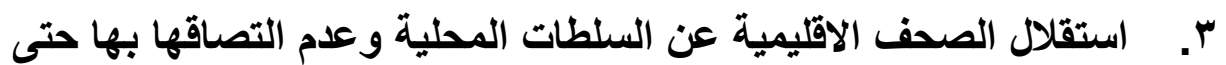

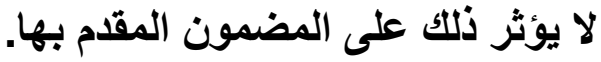
؛. الاستقزار الوظيفى والمادى للعاملين بها وصرف حواف افز ماليه وتثجيعيه لهم . •.وجود كوادر من الصحفيين المؤهلين ويكونوا من خريجى اقسام وكليات

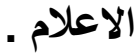
7. الوعى الكافى وتوعيه الجمهور باهمية الصحافة الاقليمية فى المجتمع

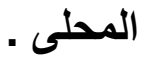


اتجاهات جمهور الخبراء نحو الصحافة الإقليمية في صعيد مصر .. دراسة ميدانية

V. زيادة المضمون الجيد المقدم من الصحافة الاقليمية حتى تزيل نسبة انقرائية الجمهور للصحف.

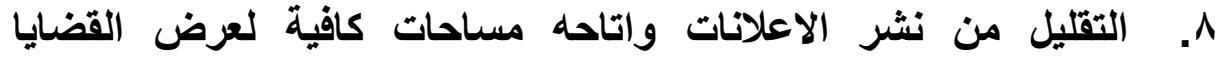
والمشكلات الهامه التى تخص المجتمع والجمهور المحلى ختى تخدم فئه

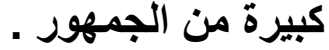

9. توفير مطابع فى المحافظات عندها القدرة على طبع الصحف.

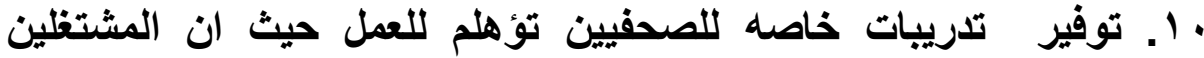

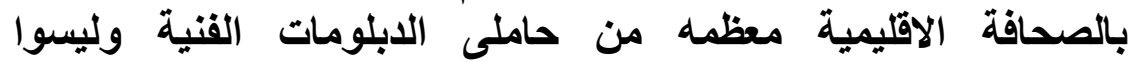
متخصصين. - المافه

11. توفير الأجهزة التكنولوجية الحديثة داخل الصحف .

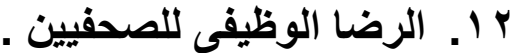

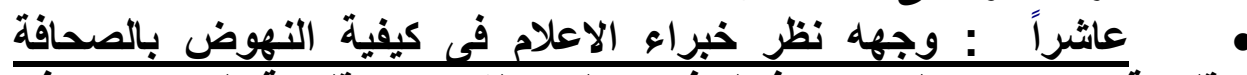

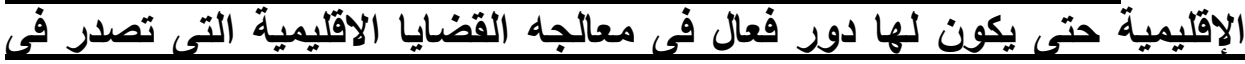

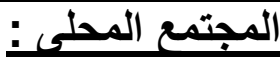

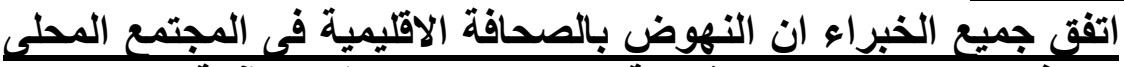

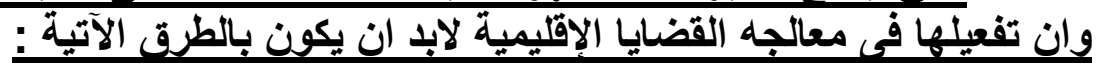

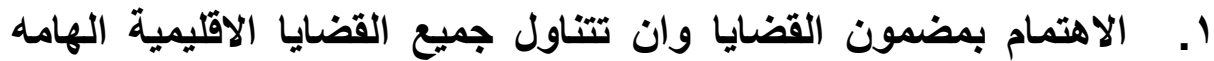

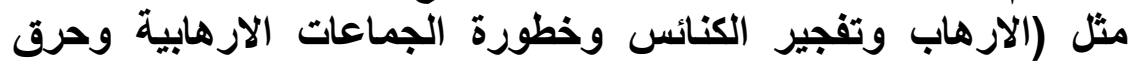

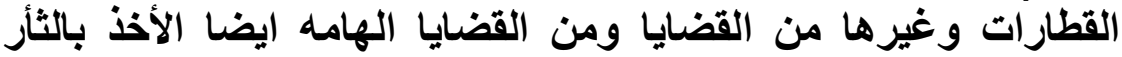

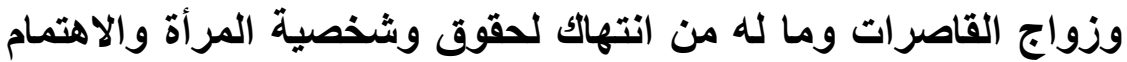

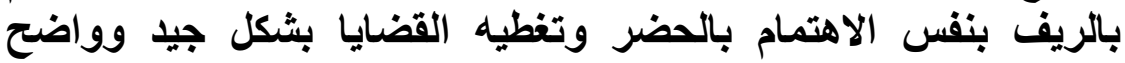
لالجمهور. r. زيادة الأجور للصحفيين ووضع سياسة تحريرية محددة للصحافة

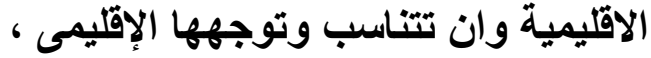

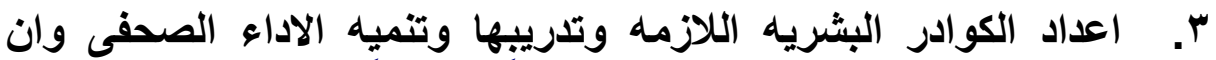

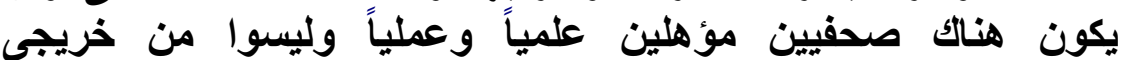
الابلومات الفنية. ؛. . الموضوعيه والصدق فى عرض القضايا والمشكلات داخل المجتمع

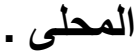
•. اتاحه المواقع الألكترونية للصحف الاقليمية حتى تعرض القضايا بشكل

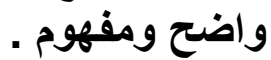


7. . توفير الدعم المادى اللازم لأصدار الصحف والتمويل بعيداً عن النظام

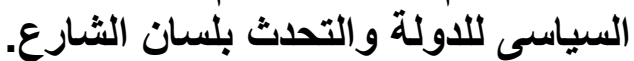

V. الاهتمام بمضمون القضايا المطروحه ومراعاة المشكلات الداخلية

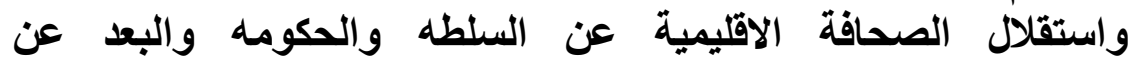

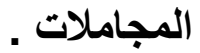

^. الاهتمام بالاخراج الصحفى الجيا والطباعه والورق وذلتك لعرض القضايا

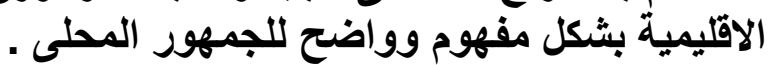
9 . . تثجيع المواطنين فى المجتمع المحلى للصحف الاقليمية . • 1 ـ تعاون مؤسسات المجتمع الرسمية والمدنية مع الصحف الإقليمية .

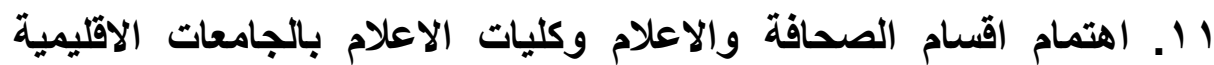

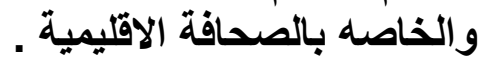

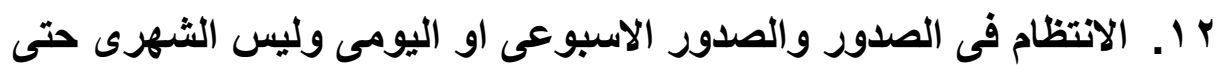

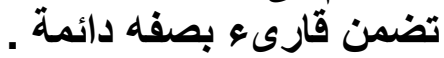

rا. التقليل من الاعلانات وتخصيص فأهله مساحات كافية لعرض القضايا

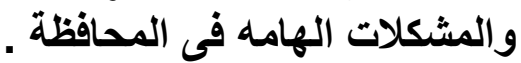

ع ا. . عمل شر اكه فى التدريب بين المؤسسات الأعلامية والصحفية الكبرى.

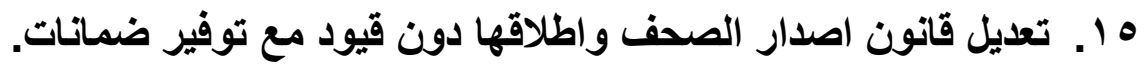
17 ا. وضع اهداف المجتمع المحلى محل التركيز والاهتمام وبالتالى اختيار الاخبار التى يحتاجها المواطن المحلى ومعرفه متطلباته واحتياجاته .

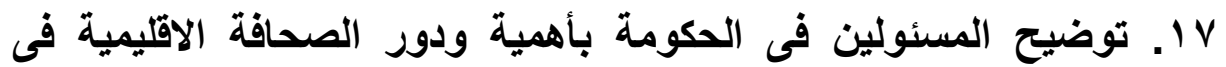
المجتمع المحلى . المبنول

1 1. اختيار رؤساء تحرير الصحف الاقليمية من الاقليم المعايشين لمشاكله . نتنائم الدراسة :

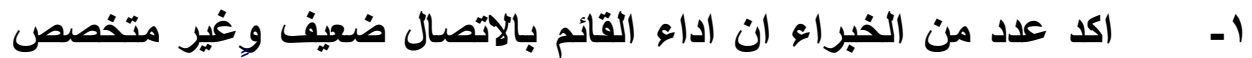

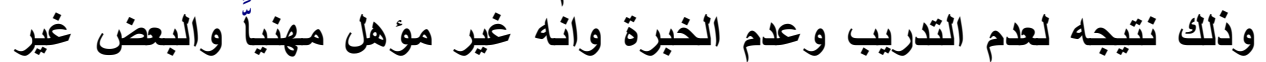

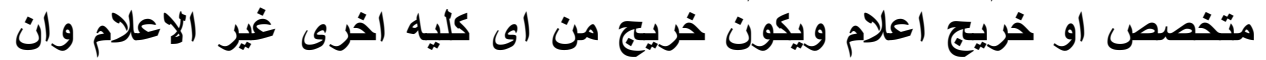

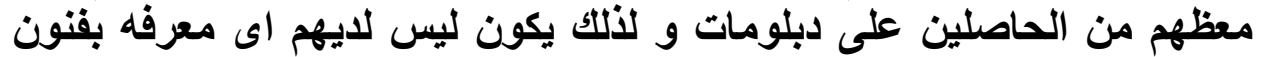

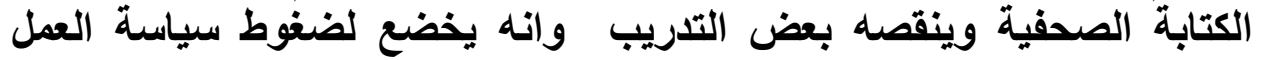

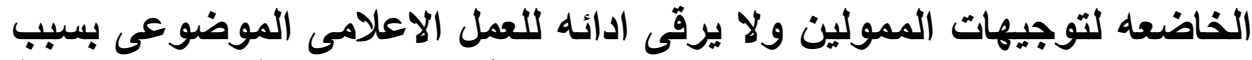

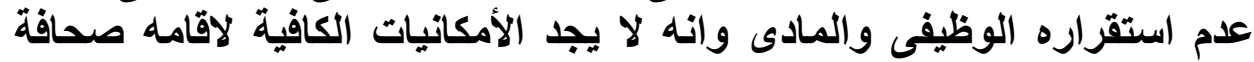

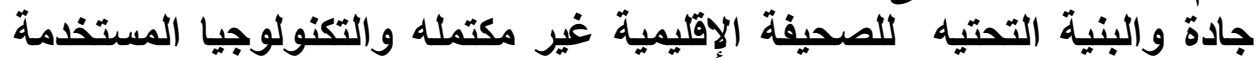

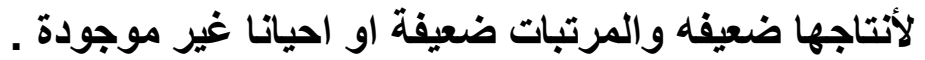


r- اوضح عدد من الخبراء ان للصحافة الإقليمية دور جيد فى تثميه

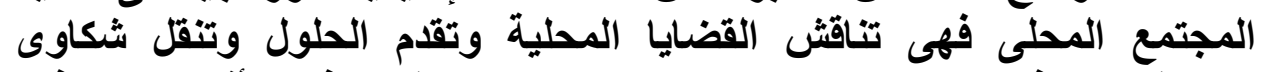

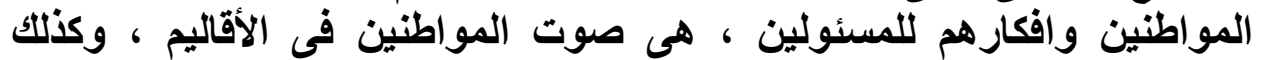

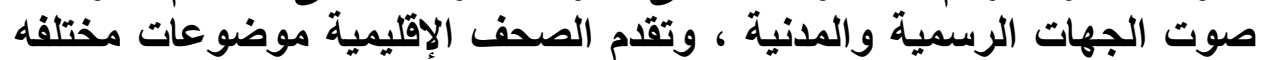

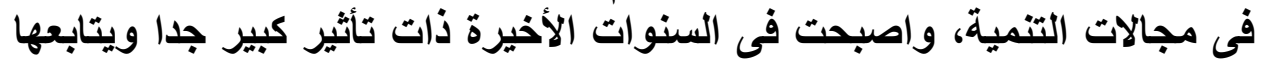

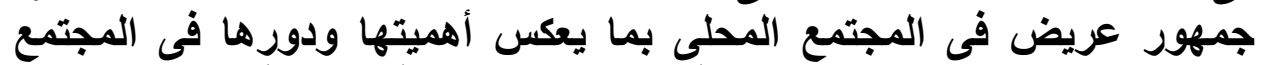

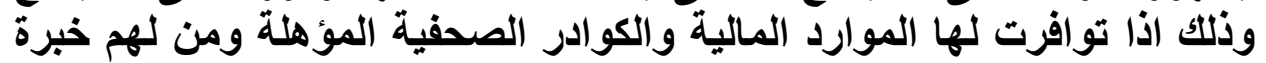

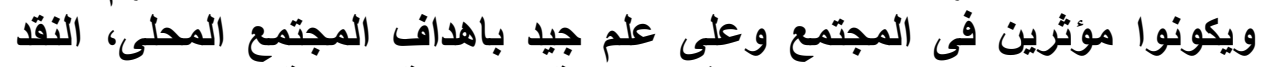

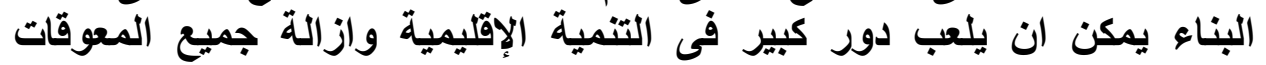

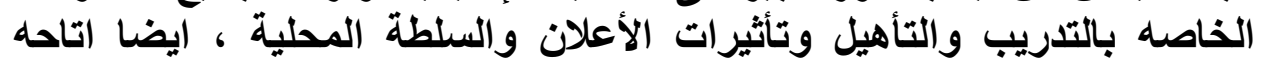

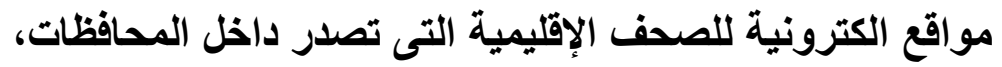

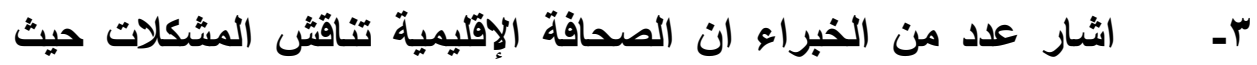

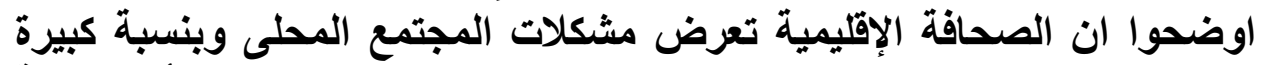

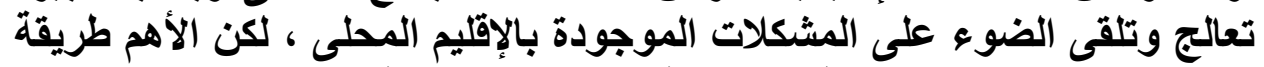

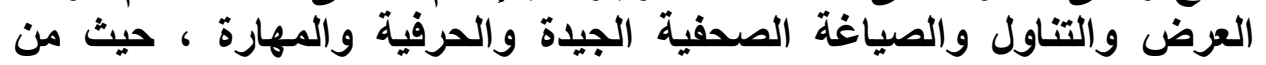

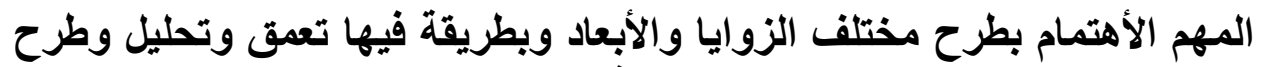

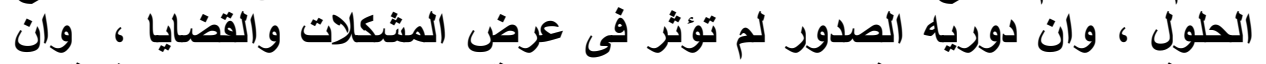

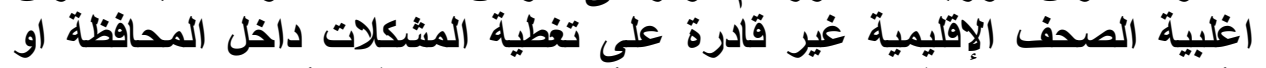

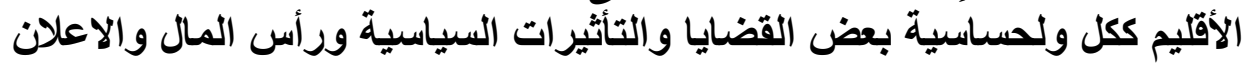

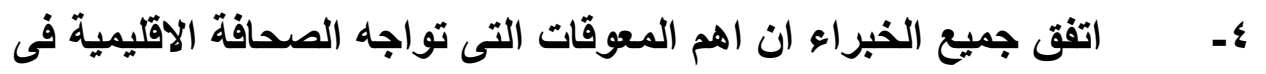

صعيد مصر هى : • مثكلة الاعم المالى " التمويل "، حيث لا يوجد استقلال مالى او او ادارى مما

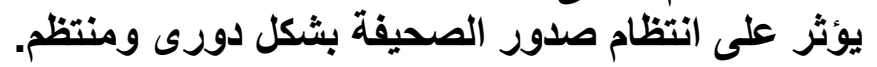

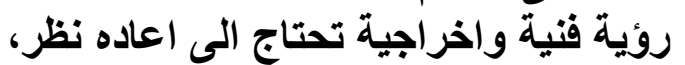

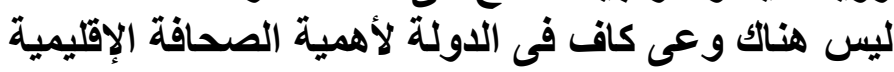

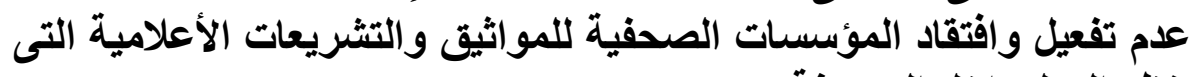
تنظم العمل داخل الصحيفة . 
مجلة كلية الآداب، جامعة سوهاج، العدد الخمسون، الجزء الثاني، يناير 19 ـ ب م

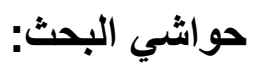

(') عزة عبد العزيز عبد اللاه عثمان ، الجوهرة بنت فهد الزامل "اتجاهات الصحافة السعودية

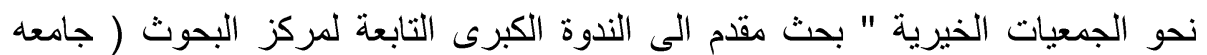

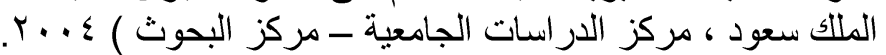

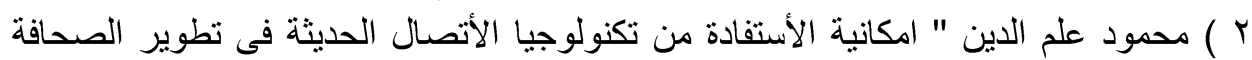

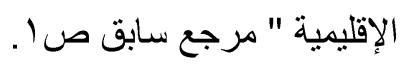
" ) عاطف محمد محمد سعد " أطر معالجه قضايا المجتمعات المحلية فى الصحافة الإقليمية

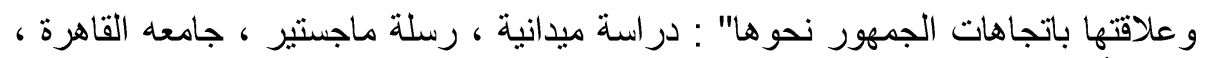

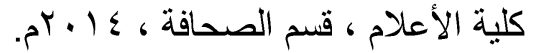

§)Flemming , Kenneth and Steffens, Brianne Understanding Readers local .Newspapers and Editorial Journalism in Small Communities paper presented at the annual meeting of the international and communication Association ,Marriot Hotel Chicago ,II,May 20.2009

online.

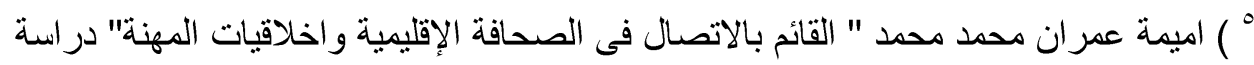

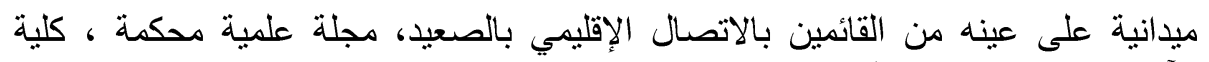

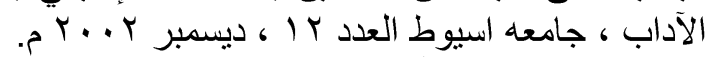

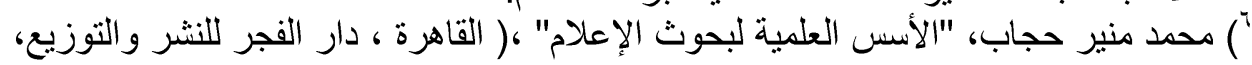

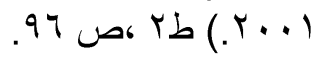

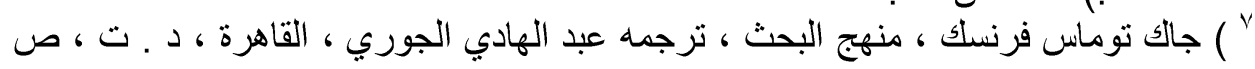

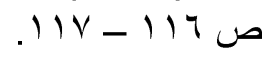

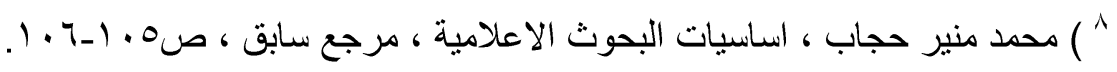

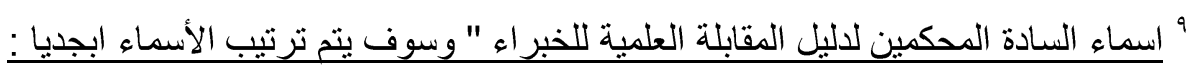

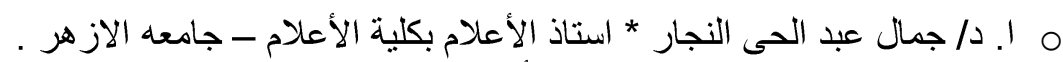

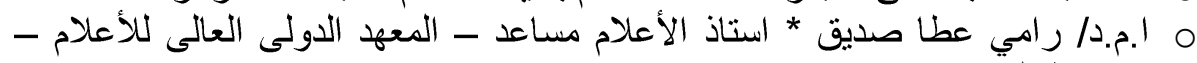
م ا.م.د / أسدر الثروق. محمد وهبي * استاذ الأعلام المساعد ـ كليه الآداب ـ قسم الأعلام ـ

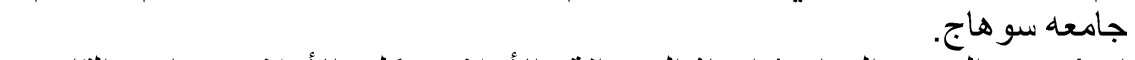
م ا. د/ سعيد الغريب النجار * استاذ الصحافة والأعلام ـ كليه الأعلام - جامعه القاهرة.

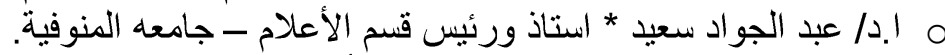

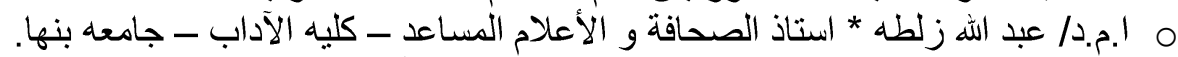
م 1. د اعزه عبد العزيز عثمان * استاذ ورئيس قسم الأعلام ـ كليه الآداب ـ جامعادها م ا.م.د / محمد عبد البديع السيد * استاذ الاعلام المساعد ورئيس قسم الأعلام جامعه بنها. 
اتجاهات جمهور الخبراء نحو الصحافة الإقليمية في صعيد مصر .. دراسة ميدانية

م ا. دا نجوى كامل * استاذ ورئيس قسم الصحافة السابق - بكلية الأعلام - جامعه

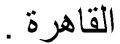

م ا. د / هاله كمال نوفل * استاذ الأعلام و عميد كلبه الأعلام وتكنولوجيا الاتصال -

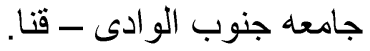
') محمد منير حجاب : الاعلام والتتمية الثناملة" ، طب ، (القاهرة : دار الفكر العربى، 1999 r ( ' ' ) ابر اهيم عبد اله المسلمى: " الصحافة الإقليمية " ، طب ( القاهرة ، دار العربى للنشر

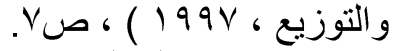

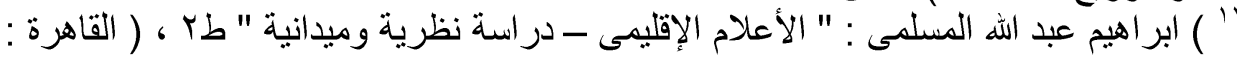

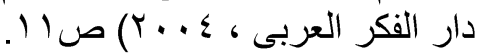

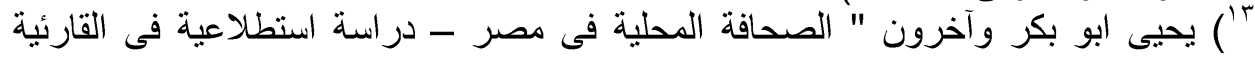

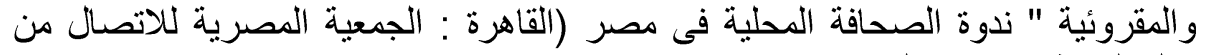

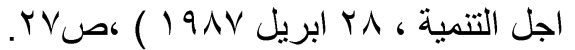

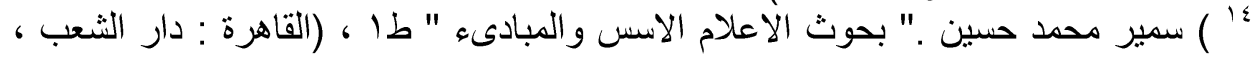

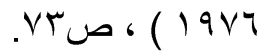

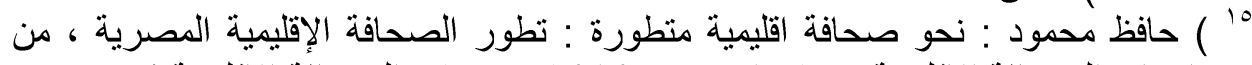

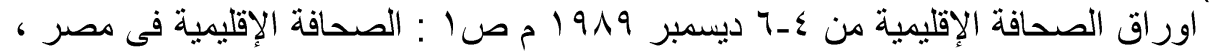

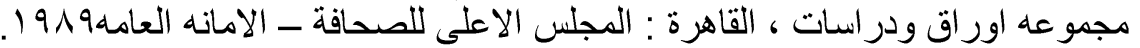

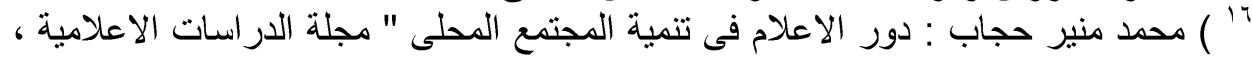

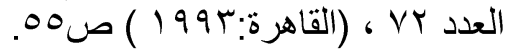

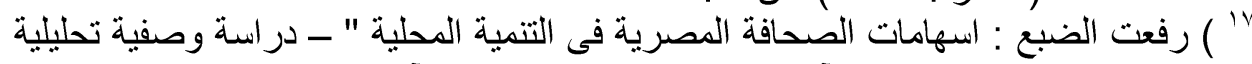
مقارنه ، المنيا :مجلة كلية الآداب و العلوم الانسانبة ، كلية الآداب ، جامعه المنيا ، . . . ، ،

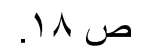

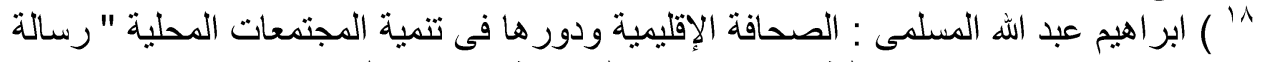

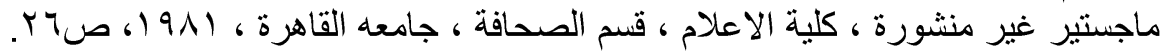

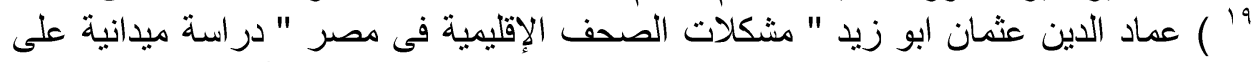

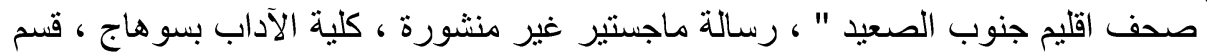

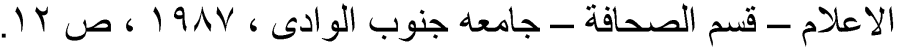

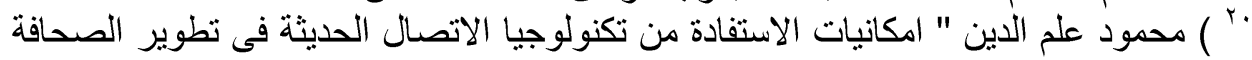

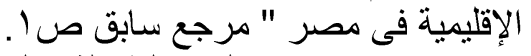

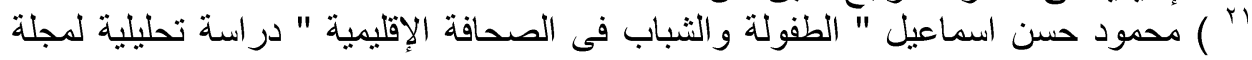

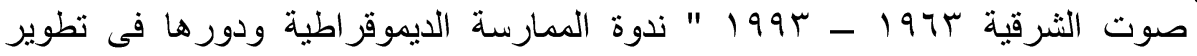

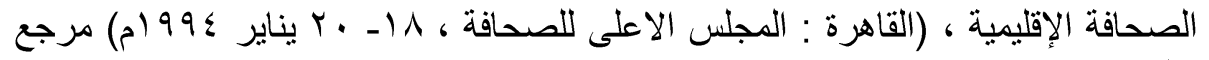

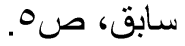

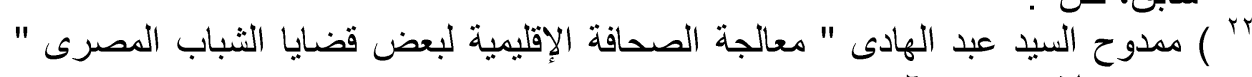

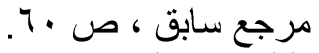

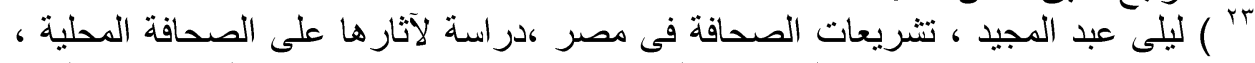
ص؛ ، من اوراق ندوة : الممارسة الديموقر اطية ودور ها فى تطوير الصحافة الصالئ الإقليمية 


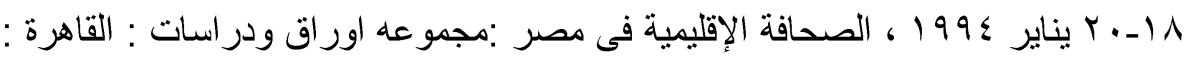

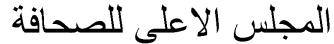

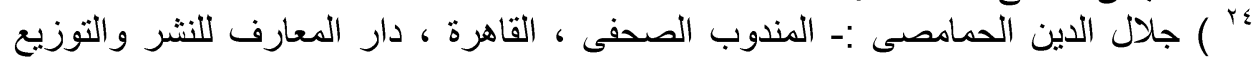

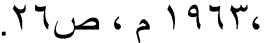
ro

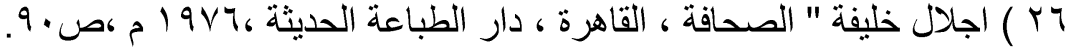

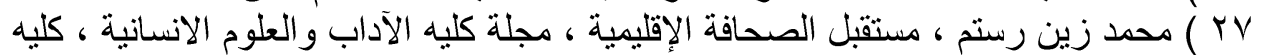

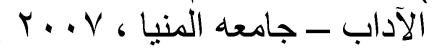

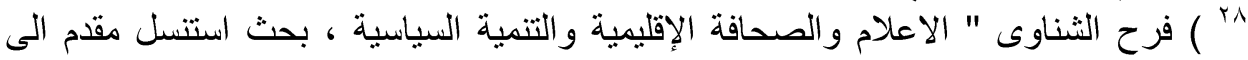

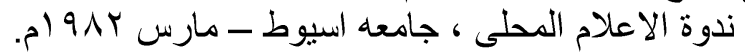

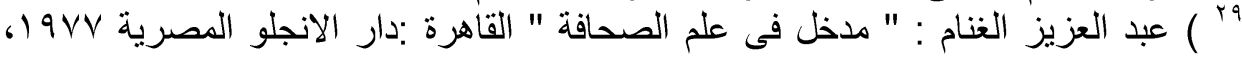

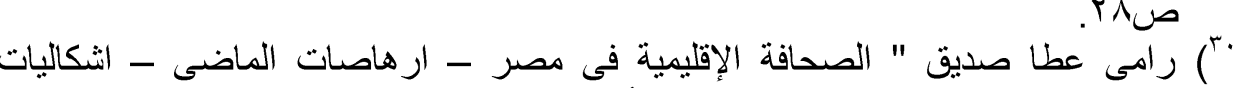

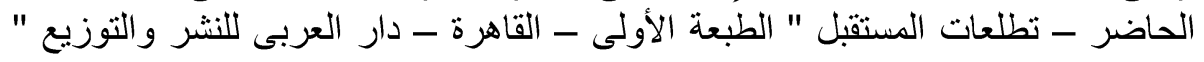

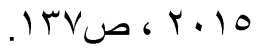
"rآعماد الدين عثمان ابو زيد "مشكلات الصحافة الإقليمية فى مصر ــ دراسة ميدانية " مرجع

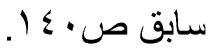

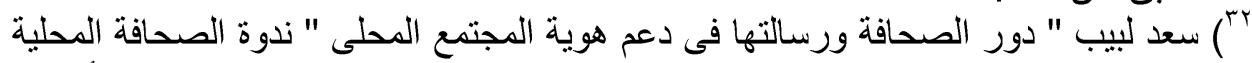

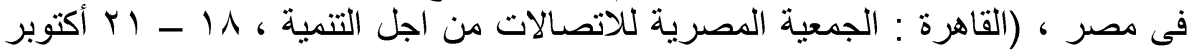

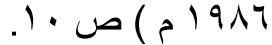
"rr حافظ محمود " نحو صحافة إقليمية متطورة :تظور الصحافة الإقليمية فى مصر " مرجع سابق 7. ( م رامى عطا صديق :- استاذ اعلام المساعد بالمعهد العالى للاعلام باكاديمية الثروق

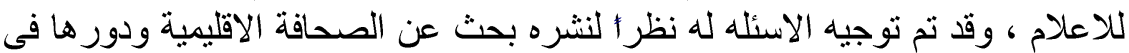

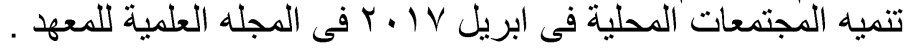

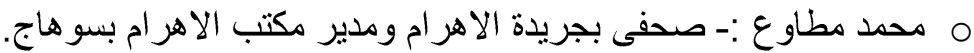
م حربى عبد الهادى:- نائب رئيس تحرير جريدة الجمهورية ومدير مكتب جريدة الإئ م اسماء عبد الراضية بسوهاج. السمان :- مدرس مساعد بكلية الآداب قسم الاعلام - جامعهد

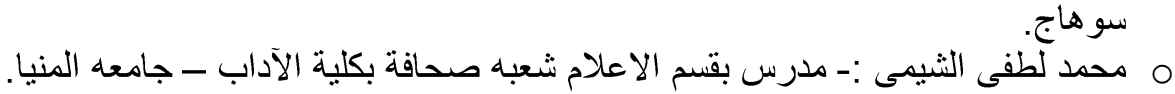

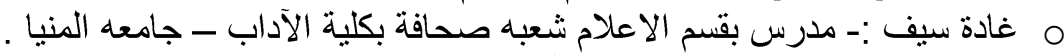

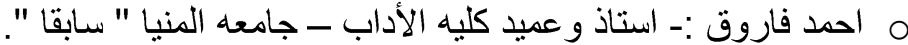

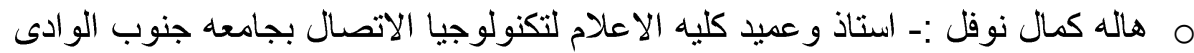
" ق قنا ". م مصطفى الجزيرى :- مدرس بقسم العلاقات العامه بكليه الاعلام وتكنولوجيا الاتصال

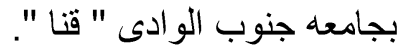
م سارة محى الدين محمد :- مدرس مساعد بقسم العلاقات العامه بكليه الاعلام وتكنولوجيا 
اتجاهات جمهور الخبراء نحو الصحافة الإقليمية في صعيد مصر .. دراسة ميدانية

م شيماء محسن مبارك :- معيدة بقسم الصحافة بكليه الاعلام وتكنولوجيا الاتصال بجامعه جنوب الوادى " قناء ".

هناء محمد عرب :- معيدة بقسم الاذاعه و التلفزيون بكليه الاعلام وتكنولوجيا الاتصال

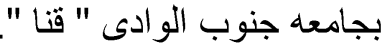

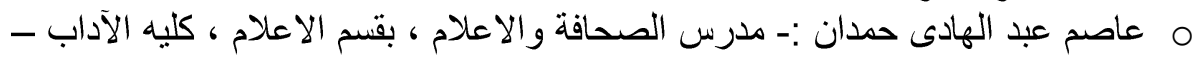
جامعه سوهاج o عبده قناوى :- مدرس بقسم العلاقات العام بكليه الاعلام وتكنولوجيا الاتصال بجامعه

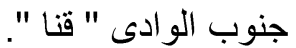
o خالد حسن :- صحفى بجريدة الاخبار ، ومدير مكتب جريدة الاخبار بسوهاج .

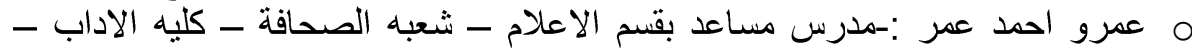
جامعه سوهاج. O مرزوق عبد الحكم العادلى :- الخبير الاعلامى ، استاذ الصحافة والاعلام بكليه الاداب

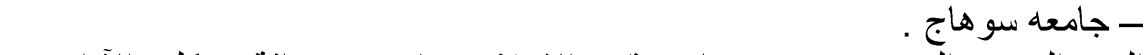
o السبد الحسين السبد:- مدرس مساعد بقسم الاعلام ـ شعبه صحافة ـ كليه الآداب جامعه سو هاج. (ro

o عزه عبد العزيز عبد اللله :- استاذ ورئيس قسم الاعلام - كليه الآداب - جامعه سوهاج. م فاطمه الزهاج هر اء صالح :- استاذ الاذاعاقو التلفزيون المساعد ـكليه الآداب ـ قسم الاعلام م سحر وهبى :- استاذ الصحافة و الاعلام المساعد ـ كليه الاداب - قسم الاعلام -

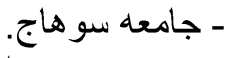
جامعه سو هاج.

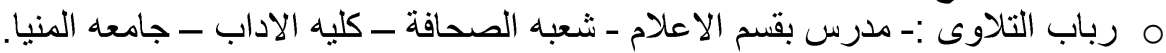
O ملوى ابو العلا الثريف :- استاذ الاعلام المساعد ورئيس قنم الاعلام ــ كليه الآدابجامعه المنيا. م محمود حمدى :- استاذ الاعلام بكلية الاداب - جامعه المنيا. O شيرين فاروق :- مدرس مساعد بقسم الاعلام - شعبه الاذاعه والتلفزيلا الآداب - مامعه المنيا. O شيماء محمد طاوى :- معيده بقسم الاعلام شعبه الاذاعه والتفزيون - كليه الادابجامعه المنيا. م محمد محفوظ الزهرى :- استاذ العلاقات العامه ووكليه كليه الاعلام وتكنولوجيا

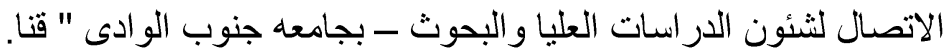

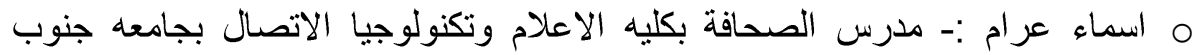

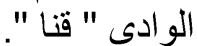

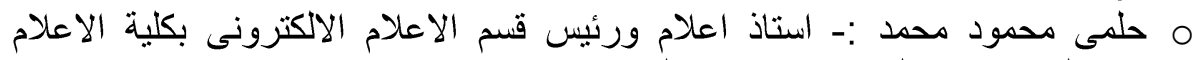

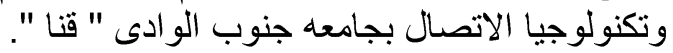
م محمد عبد العزيز عصيدة :- مدرس بقسم الاذاعه والتلفزيون بكلية الاعلام وتكنولوجيا

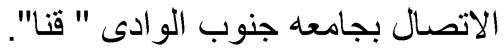
م الهام سيد السايح :- مدرس مساعد بقسم الاذاعها والتفزيون بكلية الاعلام وتكنولوجيا

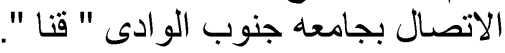

\section{\&}


مجلة كلية الآداب، جامعة سوهاج، العدد الخمسون، الجزء الثاني، يناير 19 ـ ب م

م ابو الحسن راثد :- معيد بقسم الصحافة ، كليه الاعلام وتكنولوجيا الاتصال بجامعه

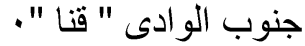

م شبيرين فاروق :- مدرس مساعد بقسم الاعلام - شعبه الاذاعه والتلفزيون - كليه

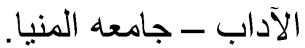

o محمد لطفى الثيمى :- مدرس بقسم الاعلام شعبه صحافة بكلية الآداب - جامعه المنيا.

م عاصم عبد الهادى حمدان :- مدرس الصحافة والاعلام ، بقسم الاعلام ، كليه الآداب ـ

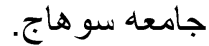

م رامى عطا صديق :- استاذ اعلام المساعد بالمعهد العالى للاعلام باكاديمية الثروق

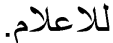

م احمد فاروق :- استاذ و عميد كليه الأداب - جامعه المنيا " سابقا ".

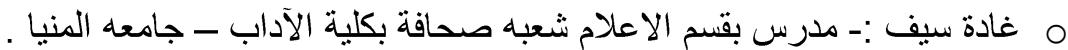
( ) وهم السادة:

م محمد عبد العزيز عصيدة :- مدرس بقسم الاذاعه والتلفزيون بكلية الاعلام وتكنولوجيا

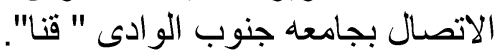
م ابو الحسن راثد :- معيد بقسم الصحافة ، كليه الاعلام وتكنولوجيا الاتصال بجامعه

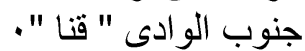

م مصطفى الجزيرى :- مدرس بقسم العلاقات العامه بكليه الاعلام وتكنولوجيا الاتصال

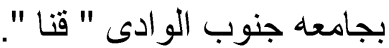

م سارة محى الدين محمد :- مدرس مساعد بقالئم العلاقات العامه بكليه الاعلام وتكنولوجيا

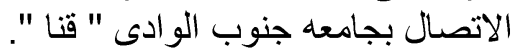
هناء محمد عرب :- معيدة بقسم الاذاعه و التلفزيون بكليه الأليه الاعلام وتكنولوجيا الاتصال

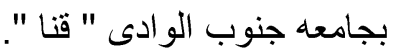

o محمود حمدى :- استاذ الاعلام بكلية الاداب - جامعابه المنيا. م سلوى ابو العلا الثريف :- استاذ الاعلام المساعد ورئيس قسم الاعلام ـ كليه الآدابـ

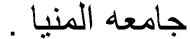
م عمرو احمد عمر :-مدرس مساعد بقسم الاعلام - شعبه الصحافة ـ كلبه الاداب -

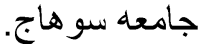
م مرزوق عبد الحكم العادلى :- الخبير الاعلامى ، استاذ الصحافة والاعلام بكليه الاداب م عزه عبد العزيز عبد اللاه :- استاذ ورئيس قسم الاعلام - كليه الآداب - جامعه م اسماء عبد الراضى السمان :- مدرس مساعد بكلية الآداب قسم الاعلام - جامعه

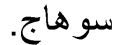

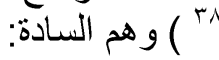

م عبده قناوى :- مدرس بقسم العلاقات العام بكليه الاعلام وتكنولوجيا الاتصال بجامعه

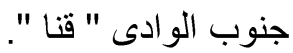
م هاله كمال نوفل :- استاذ وعميد كليه الاعلام لتكنولوجيا الاتصال بجامعه جنوب الوادى

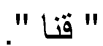

\section{\&Yr}


اتجاهات جمهور الخبراء نحو الصحافة الإقليمية في صعيد مصر .. دراسة ميدانية

م شيماء محسن مبارك :- معيدة بقسم الصحافة بكليه الاعلام وتكنولوجيا الاتصال بجامعه

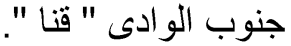
م حربى عبد الهادى:- نائب رئبس تحرير جريدة الجمهورية ومدير مكتب جريدة الجمهورية بسو هاج. O محمد مطاوع :- صحفى بجريدة الاجئ الهر ام ومدير مكتب الاهر ام بسو هاج.

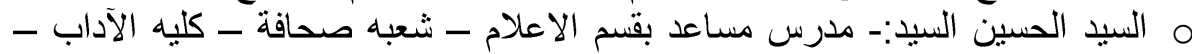
جامعاه سو هاج.

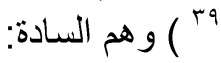

O الهام سيد السايح :- مدرس مساعد بقسم الاذاعه و التفزيون بكلية الاعلام وتكنولوجيا

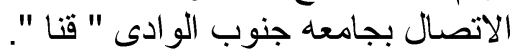
O حلمى محمود محمد :- استاذ اعلام ورئيس قسم الأنس الاعلام الالكترونى بكلية الاعلام

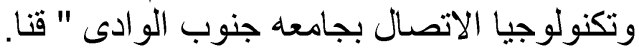

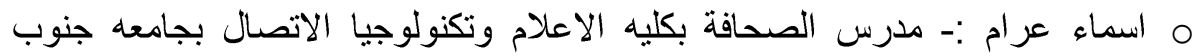

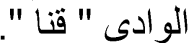
م محمد محفوظ الزهرى :- استاذ العلاقات العامه ووكليه كليه الاعلام وتكنولوجيا الاتصال لثنئون الدر اسات العليا والبحوث ـ بجامعه جنوب الو ادى " قنا.

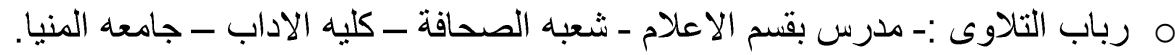

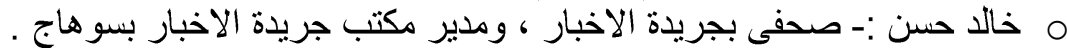

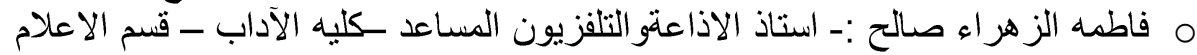
م سحر وهبى :- استاذ الصحافة و الاعلام المساعد ـ كليه الاداب - قسم الاعلام جامعه سو هاج. O شيماء محمد طاوى :- معيده بقسم الاعلام شعبه الاذاعه والتفزيون - كليه الاداب-

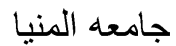
•

o خ الد حسن :- صحفى بجريدة الاخبار ، ومدير مكتب جريدة الاخبار بسوهاج . O حربى عبد الهادى:- نائب رئيس تحرير جريدة الجمهورية ومدير مكتبر مائب جريدة

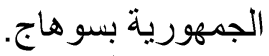
o عزه عبد العزيز عبد اللاه :- استاذ ورئيس قسم الاعلام - كليه الآداب - جامعه م سحر وهبى :- استاذ الصحافة و الاعلام المساعد ـ كليه الاداب - قسم الاعلام جامعه سو هاج. O ر رباب التلاوى :- مدرس بقسم الاعلام - شعبه الصحافة ـ كليه الاداب ـ جامعاده المنيا.

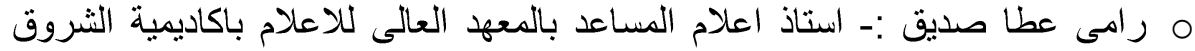

لناعلام. O محمد مطاوع :- صحفى بجريدة الالهر ام ومدير مكتب الاهر ام بسوهاج.

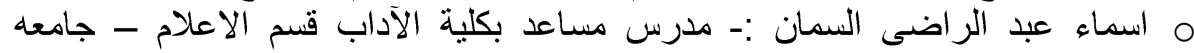
م سوهى هحمود محمد :- استاذ اعلام ورئيس قسم الاعلام الالكترونى بكلية الاعلام

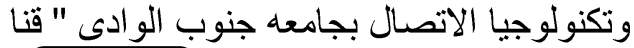


مجلة كلية الآداب، جامعة سوهاج، العدد الخمسون، الجزء الثاني، يناير 19 ـ ب م

م السيد الحسين السيد:- مدرس مساعد بقسم الاعلام ـ شعبه صحافة ـ كلبه الآداب ـ

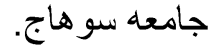

م عمرو احمد عمر :-مدرس مساعد بقسم الاعلام ـ شعبه الصحافة ـ كلبه الاداب ـ

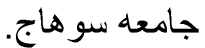
م مرزوق عبد الحكم العادلى :- الخبير الاعلامى ، استاذ الصحافة والاعلام بكليه الاداب

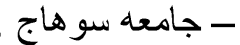
م سلوى ابو العلا الثشريف :- استاذ الاعلام المساعد ورئيس قسم الاعلام ـ كليه الآدابـ

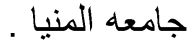
o محمود حمدى :- استاذ الاعلام بكلية الاداب - جامعه المنيا.

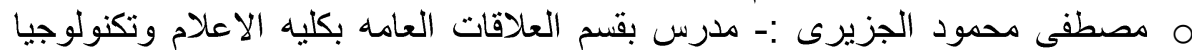
الاتصال بجامعه جنوب الو الو ادى " قنا ".

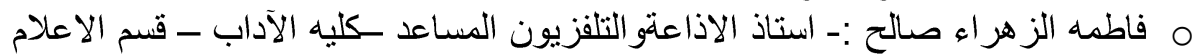

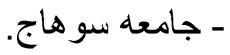
م غادة سيف :- مدرس بقسم الاعلام شعبه صحافة بكلية الآداب ـ جامعه المنيا .

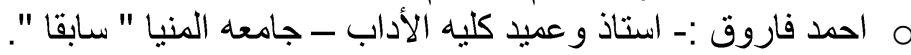
م عاصم عبد الهادى حمدان :- مدرس الصحافة والاعلام ، بقسم الاعلام ، كليه الآداب ـ

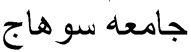
م عبده قناوى :- مدرس بقسم العلاقات العام بكليه الاعلام وتكنولوجيا الاتصال بجامعه

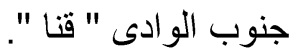

م محمد محفوظ الزهرى :- استاذ العلاقات العامه ووكليه كليه الاعلام وتكنولوجيا

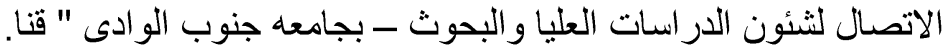
م اسماء عرام :- مدرس الصحافة بكليه الاعلام وتكنولوجيا الإليات الاتصال بجامعاله جنوب الو ادى " ق التنا ".

م محمد عبد العزيز عصيدة :- مدرس بقسم الاذاعه والتلفزيون بكلية الاعلام وتكنولوجيا الاتصال بجامعه جنوب الو الو ادى " قنا". م الهام سيد السايح :- مدرس مساعد بقال بقسم الاذاعه والتفزيون بكلية الاعلام وتكنولوجيا الاتصال بجامعه جنوب الو الو ادى " قنا ". م ابو الحسن راثند :- معيد بقسم الصحافة ، كليه الاعلام وتكنولوجيا الاتصال بجامعه

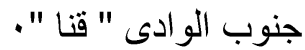
م محمد لطفى الثيمى :- مدرس بقسم الاعلام شعبه صحافة بكلية الآداب - جامعه المنيا. م سارة محى الدين محمد :- مدرس مساعد بقسم العلاقات العامه بكليه الاعلام وتكنولو الأوجيا

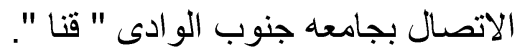
م شيماء محسن مبارك :- معيدة بقسم الصحافة بكليه الاعلام وتكنولوجيا الاتصال بجامعه

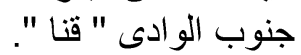
هناء محمد عرب :- معيدة بقسم الاذاعه و التلفزيون بكليه الاعلام وتكنولوجيا الاتصال

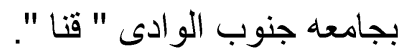
( ) وهم السادة:

م هاله كمال نوفل :- استاذ و عميد كليه الاعلام لتكنولوجيا الاتصال بجامعه جنوب الوادى

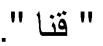

\section{$\varepsilon r \varepsilon$}


اتجاهات جمهور الخبراء نحو الصحافة الإقليمية في صعيد مصر .. دراسة ميدانية

م شبرين فاروق :- مدرس مساعد بقسم الاعلام - شعبه الاذاعه والتلفزيون - كليه

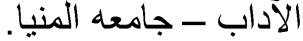
م شيماء محمد طاوى :- معيده بقسم الاعلام شعبه الاذاعه والتفزيون - كليه الاداب-

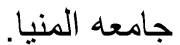

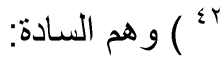

o هاله كمال نوفل :- استاذ وعميد كليه الاعلام لتكنولوجيا الاتصال بجامعه جنوب الوادى " ق قنا ". م هناء محمد عرب :- معيدة بقسم الاذاعه و التلفزيون بكليه الاعلام وتكنولوجيا الاتصـال

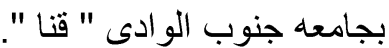
O رامى عطا صديق :- استاذ اعلام المساعد بالمعهد العالى للاعلام باكاديمية الثروق لماعلام. م الهام سيد السايح :- مدرس مساعد بقسم الاذاعه والتقزيون بكلية الاعلام وتكنولوجيا

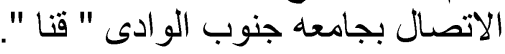
م سارة محى الدين محمد :- مدرس مساعد بقال بقدم العلاقات العامه بكليه الاعلام وتكنولوجيا

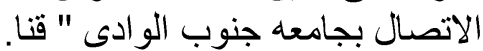
م عاصم عبد الهادى حمدان :- مدرس الصحافة لهافة والاعلام ، بقسم الاعلام ، كليه الآداب ـ

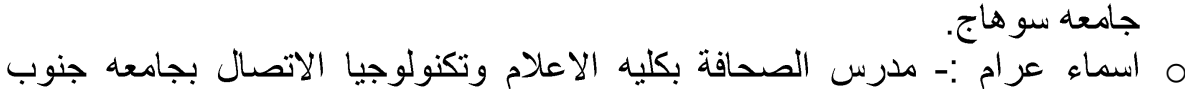

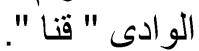
o غادة سيف :- مدرس بقسم الاعلام شعبه صحافة بكلية الآداب - جامعه المنيا . Or م عبده قناوى :- مدرس بقسم العلاقات العام بكليه الاعلام وتكنولوجيا الاتصال بجامعه

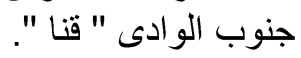

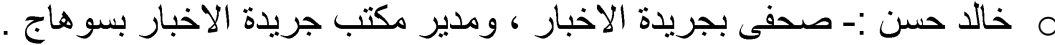
م عمرو احمد عمر :-مدرس مساعد بقسم الاعلام - شعبه الصحافة ـ كليه الاداب ـ

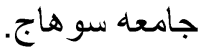
م مرزوق عبد الحكم العادلى :- الخبير الاعلامى ، استاذ الصحافة والاعلام بكلبه الاداب

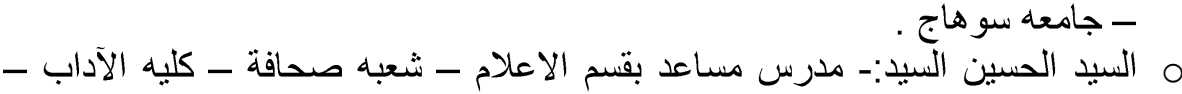
جامعاه سوهاج. م عزه عبد العزيز عبد اللاه :- استاذ ورئيس قسم الاعلام ـ كليه الآداب - جامعه

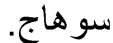
م فاطمه الزهر اء صالح :- استاذ الاذاعةو التلفزيون المساعد ـكليه الآداب ـ قسم الاعلام م سحر وهبى :- استاذ الصحافة و الاعلام المساعد ـ كليه الاداب ـ قسم الاعلام -

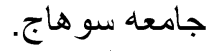
م رباب التلاوى :- مدرس بقسم الاعلام - شعبه الصحافة ـ كليه الاداب ـ جامعهد المنيا. م سلوى ابو العلا الثريف :- استاذ الاعلام المساعد ورئيس قسم الاعلام ـ كليه الآدابـ 
مجلة كلية الآداب، جامعة سوهاج، العدد الخمسون، الجزء الثاني، يناير 19 ـ ب م

o محمود حمدى :- استاذ الاعلام بكلية الاداب - جامعه المنيا. م شيرين فاروق :- مدرس مساعد بقسم الاعلام - شعبه الاذاعه والتابلفزيون - كليه

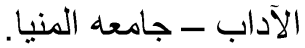
م شيماء محمد طاوى :- معيده بقسم الاعلام شعبه الاذاعه و التفزيون - كليه الاداب-

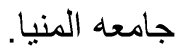
O محدد محفوظ الزهرى :- استاذ العلاقات العامه ووكليه كليه الاعلام وتكنولوجيا

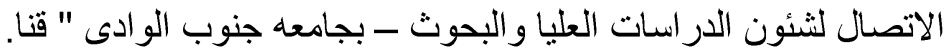

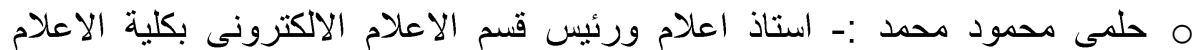

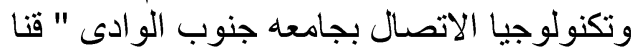
م محمد عبد العزيز عصيدة :- مدرس بقالئم الاذاعاعه والتلفزيون بكلية الاعلام وتكنولوجيا

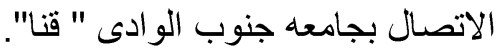
م ابو الحسن راثد :- معيد بقسم الصحافة ، كليه الاعلام وتكنولوجيا الاتصال بجامعه

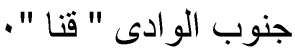

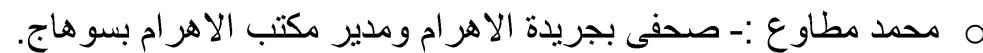
م اسماء عبد الراضى السمان :- مدرس مساعد بكلية الآداب قسم الاعلام بـاج - جامعه سوهاج. م محمد لطفى الثيمى :- مدرس بقسم الاعلام شعبه صحافة بكلية الآداب - جامعه المنيا.

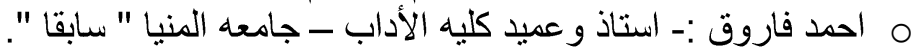
o مصطفى الجزيرى :- مدرس بقسم العلاقات العامه بكليه الاعلام وتكنولوجيا الاتصال

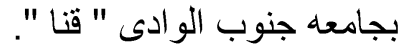
م شيماء محسن مبارك :-- معيدة بقسم الصحافة بكليه الاعلام وتكنولوجيا الاتصال بجامعه جنوب الوادى " قنار ". م حربى عبد الهادى:- نائب رئيس تحرير جريدة الجمهورية ومدير مكتب جريدة الجمهورية بسو هاج.

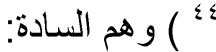

م هاله كمال نوفل :- استاذ و عميد كليه الاعلام لتكنولوجيا الاتصال بجامعه جنوب الو ادى

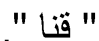
م هناء محمد عرب :- معيدة بقسم الاذاعه و التلفزيون بكليه الاعلام وتكنولوجيا الاتصال

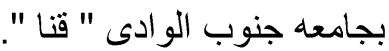
O رامى عطا صديق :- استاذ اعلام المساعد بالمعهد العالى للاعلام باكاديمية الثنروق

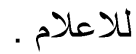
م الهام سيد السايح :- مدرس مساعد بقسم الاذاعه والتفزيون بكلية الاعلام وتكنولوجيا الاتصال بجامعه جنوب الو الو ادى " قنا ". م سارة محى الدين محمد :- مدرس مساعد بقال بقدم العلاقات العامه بكليه الاعلام وتكنولوجيا

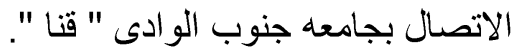

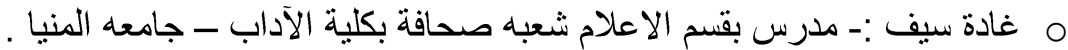

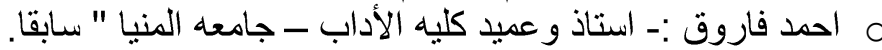

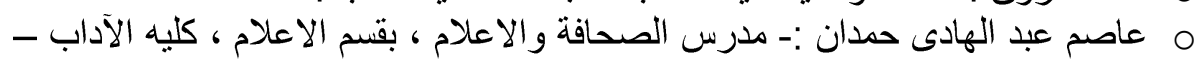
جامعه سو هاج 
اتجاهات جمهور الخبراء نحو الصحافة الإقليمية في صعيد مصر .. دراسة ميدانية

O عبده قناوى :- مدرس بقسم العلاقات العام بكليه الاعلام وتكنولوجيا الاتصال بجامعه

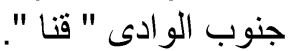

O خالد حسن :- صحفى بجريدة الاخبار ، ومدير مكتب جريدة الاخبار بسوهاج .

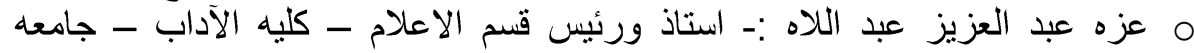

م سحر وهاج. مبى :- استاذ الصحافة و والاعلام المساعد ـ كليه الاداب - قسم الاعلام جامعه سو هاج.

م حلمى محمود محمد :- استاذ اعلام ورئيس قيم الاعلام الالكترونى بكلية الاعلام

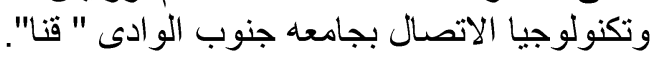

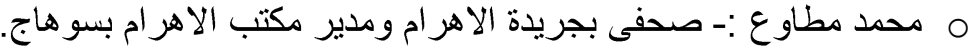

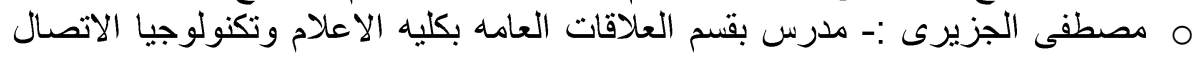

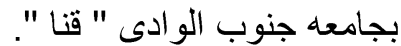
O شيماء محسن مبارك :- معيدة بقسم الصحافة بكليه الاعلام وتكنولوجيا الاتصال بجامعه

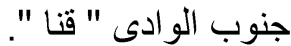
o السيد الحسبن السبد:- مدرس مساعد بقسم الاعلام ـ شعبه صحافة ـ كليه الآداب ـ جامعه سوهاج. 0 محمد لطفى الثيمى :- مدرس بقسم الاعلام شعبه صحافة بكلية الآداب - جامعه المنيا. O شيرين فاروق :- مدرس مساعد بقسم الاعلام - شعبه الاذاعه والتلفزيون - كليه

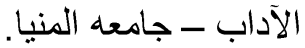
O اسماء عرام :- مدرس الصحافة بكليه الاعلام وتكنولوجيا الاتصال بجامعه جنوب

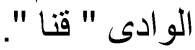
(

م رباب التلاوى :- مدرس بقسم الاعلام - شعبه الصحافة ـ كليه الاداب - جامعاده المنيا.

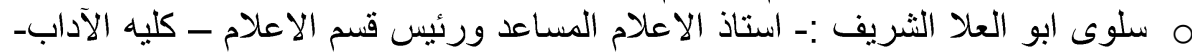

جامعه المنيا.

o محمود حمدى :- استاذ الاعلام بكلية الاداب - جامعه المنيا. O عمرو احمد عمر :-مدرس مساعد بقسم الاعلام - شعبه الصحافة ـ كليه الاداب جامعه سو هاج. O مرزوق عبد الحكم العادلى :- الخبير الاعلامى ، استاذ الصحافة والاعلام بكليه الاداب - جامعه سو هاج أل م فاطمه الزهر اء صالح :- استاذ الاذاعقو التلفزيون المساعد ـكليه الآداب ـ قسم الاعلام o اسماء عبد الراضيى السمان :- مدرس مساعد بكلية الآداب قسم الاعلام - جامعه م محمد محفوظ الزهرى :- استاذ العلاقات العامه ووكليه كليه الاعلام وتكنولوجيا

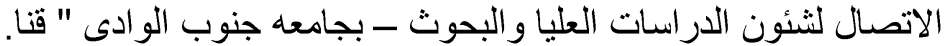

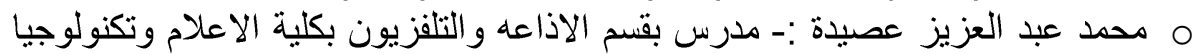

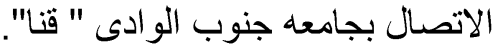
O ابو الحسن راثد :- معيد بقم الصحافة ، كليه الاعلام وتكنولوجيا الاتصال بجامعه 
مجلة كلية الآداب، جامعة سوهاج، العدد الخمسون، الجزء الثاني، يناير 19 ـ ب م

م شيماء محمد طاوى :- معيده بقسم الاعلام شعبه الاذاعه والتفزيون - كليه الاداب-

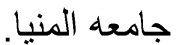
م حربى عبد الهادى:- نائب رئيس تحريز جريدة الجمهورية ومدير مكتب جريدة

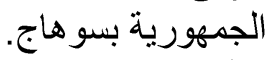

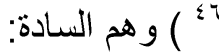

م عاصم عبد الهادى حمدان :- مدرس الصحافة والاعلام ، بقسم الاعلام ، كليه الآداب ـ

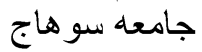
O عبده قتناوى :- مدرس بقسم العلاقات العام بكليه الاعلام وتكنولوجيا الاتصال بجامعه

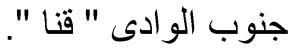
o خالد حسن :- صحفى بجريدة الاخبار ، ومدير مكتب جريدة الاخبار بسوهاج . م فاطمه الزهر اء صالح :- استاذ الاذاعتو التلفزيون المساعد ـكليه الآداب ـ قشم الاعلام م سحر وهبى :- استاذ الصحافة و الاعلام المساعد ـ كليه الاداب ـ قسم الاعلام ـ

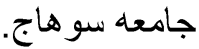
م سلوى ابو العلا الثريف :- استاذ الاعلام المساعد ورئيس قسم الاعلام ـ كليه الآدابـ

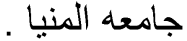
م شيرين فاروق :- مدرس مساعد بقسم الاعلام - شعبه الاذاعه والتلفزيون - كليه

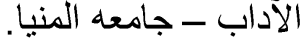

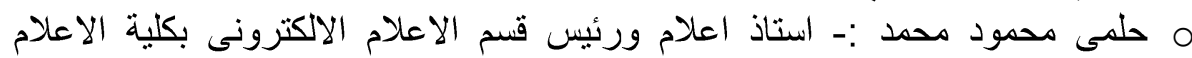

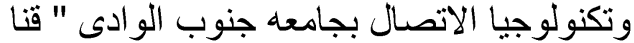

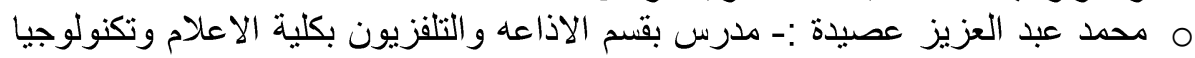
الاتصال بجامعه جنوب الو الو ادى " قدنا".

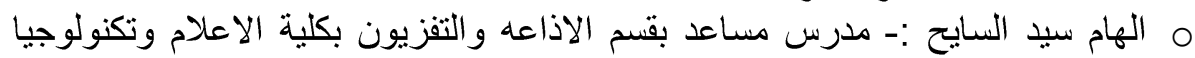
الاتصال بجامعه جنوب الو الو ادى " قنائ ".

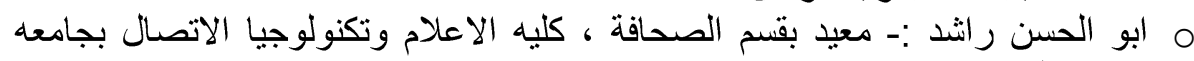

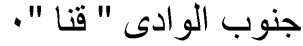
م رامى عطا صديق :- استاذ اعلام المساعد بالمعهد العالى للاعلام باكاديمية الثروق لمعاعلام. O محمد لطفى الثيمى :- مدرس بقسم الاعلام شعبه صحافة بكلية الآداب ـ جامعه المنيا.

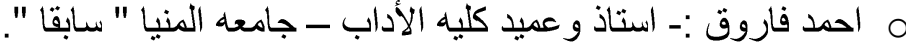

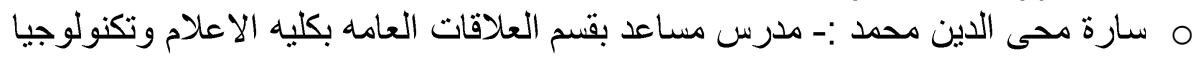

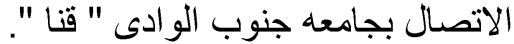

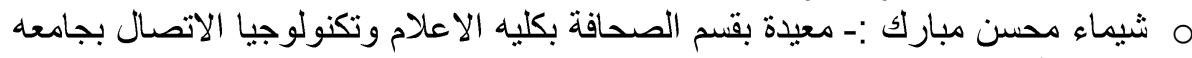
هناء محمد عرب :- معيدة بقسم الاذاعه و التلفزيون بكليه الاعلام وتكنولوجيا الاتصال

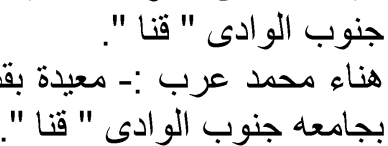

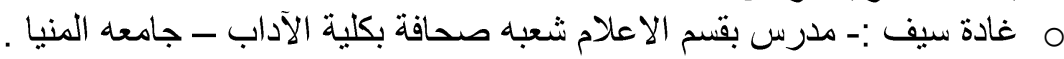

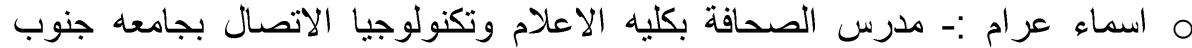

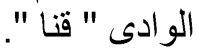


اتجاهات جمهور الخبراء نحو الصحافة الإقليمية في صعيد مصر .. دراسة ميدانية

م حربى عبد الهادى:- نائب رئيس تحريز جريدة الجمهورية ومدير مكتب جريدة الجمهورية بسوهاج. ( ) م هم السادة:

م هاله كمال نوفل :- استاذ و عميد كليه الاعلام لتكنولوجيا الاتصال بجامعه جنوب الوادى

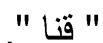
O عمرو احمد عمر :-مدرس مساعد بقسم الاعلام - شعبه الصحافة ـ كليه الاداب ـ

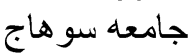
م مرزوق عبد الحكم العادلى :- الخبير الاعلامى ، استاذ الصحافة والاعلام بكليه الاداب

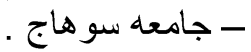
م السيد الحسين السيد:- مدرس مساعد بقسم الاعلام ـ شعبه صحافة ـ كلبه الآداب ـ جامعه سو هاج. O عزه عبد العزيز عبد اللاه :- استاذ ورئيس قسم الاعلام ـ كليه الآداب - جامعه

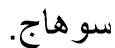
م رباب التلاوى :- مدرس بقسم الاعلام - شعبه الصحافة ـ كليه الاداب ـ جامعاده المنيا.

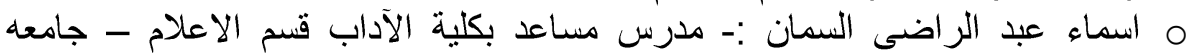

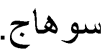

م محد محفوظ الزهرى :- استاذ العلاقات العامه ووكلبه كليه الاعلام وتكنولوجيا

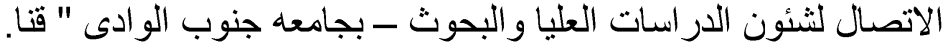

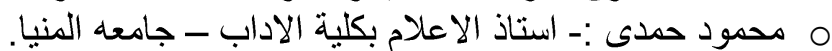
م مصطفى الجزيرى :- مدرس بقسم العلاقات العامه بكليه الاعلام وتكنولوجيا الاتصال بجامعه جنوب الو ادى " ق قلنا

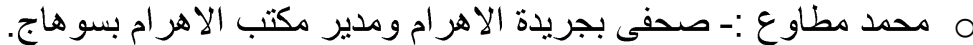

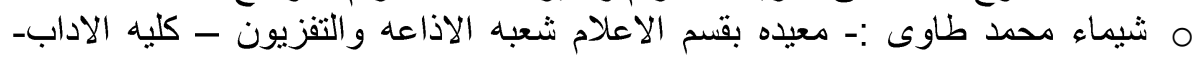

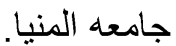


مجلة كلية الآداب، جامعة سوهاج، العدد الخمسون، الجزء الثاني، يناير 9 ـ ب م

\section{ملحق (1)}

تم عرض استمارة الخبراء على السادة الأتى اسماؤهم : الأهاء

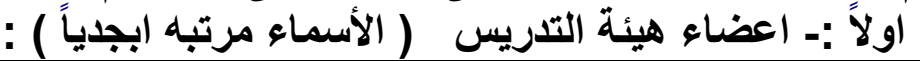

\begin{tabular}{|c|c|c|}
\hline الوظــــــــة & الأســــــم & م \\
\hline معيد بقسم الصحافة ـ كليه الاعلام وتكنولوجيا الاتصال - & على الحسن راشد & 1 \\
\hline استاذ و عميد كليه الآداب - جامعه المنيا " سابقاً " & احمد فاروق & $r$ \\
\hline مدوب الوادى " قنافة بكليه الاعلام وتكنولوجيا الاتصال جامعه & اسماء عرام & $r$ \\
\hline مامعله سوهاجد بقسم الاعلام ـ شعبه صحافة ـ كليه الآداب ـ & السمان عبد الراضى & $\varepsilon$ \\
\hline مدامعل سو هاعد بقسم الاعلام ـ شعبه صحافة ـ كليه الآداب - & السيد الحسين السيا & 0 \\
\hline 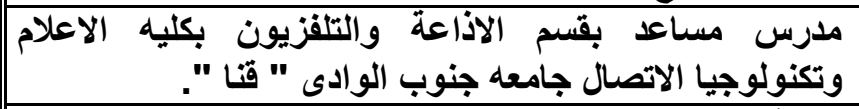 & الهام سيد السايح & 9 \\
\hline وتكنتولوجيا الاعلام ورئيس قبامعه جنوب اللوادى "لأكترونى "بكليه الاعلام & حلمى محمود محمد & $v$ \\
\hline للإعلاذ الأعلام المساعد بالمعها العالى بأكاديمية الشروق & رامى عطا صديق & $\Lambda$ \\
\hline ملدرس بقسم الاعلام - شعبه صحافة ـ كليه الآداب - جامعه & رباب التلاوى & 9 \\
\hline 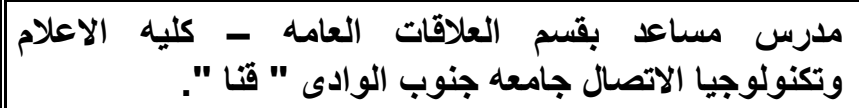 & سحمدة محى الاين & 1. \\
\hline سوهاذ الاعلام المساعد بكليه الآداب - قسم الأعلام - جامعه & سحر محمد وهبى & 11 \\
\hline قستم الاعلام - جامعلام المساعد ورئيس قسم الاعلام بكليه الاداب ـ & الشريف ابو العلا & ir \\
\hline ملآدرب - جامعه المنيا. & شيرين فاروق & ir \\
\hline معيدة بقوب الصحافة ـ ـ كليه الاعلام وتكنولوجيا الاتصال - & شيماء محسن مبارك & $1 \varepsilon$ \\
\hline معيدة بقسم الاعلام شعبه الاذاعة والتلفزيون - كليه الآداب ـ & شيماء محمد طاوى & 10 \\
\hline مدرس بقسم الاعلام شعبه صحافة بكليه الآداب - جامعه & عاصم عبد الهادى & 17 \\
\hline 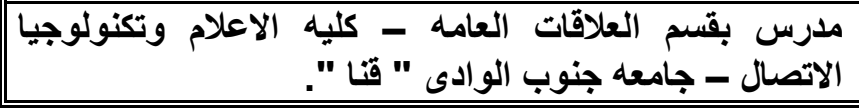 & عبده قناوى & iv \\
\hline
\end{tabular}


اتجاهات جمهور الخبراء نحو الصحافة الإقليمية في صعيد مصر ... دراسة ميدانية

\begin{tabular}{|c|c|c|}
\hline 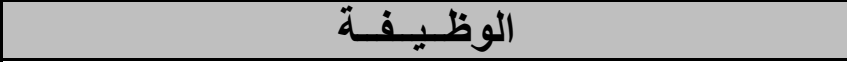 & الأســــــم & r \\
\hline استاذ ورئيس قسم الاعلام - كليه الآداب - جامعه سوهاج . & ألاه & 11 \\
\hline مدامعه سوس مساعد بقسم الاعلام ـ شعبه صحافة ـ كليه الآداب - & 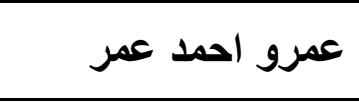 & 19 \\
\hline ملارس بقسم الاعلام شعبه صحافة - كليه الآداب - جامعه & & $r$. \\
\hline سوهاج الاعلام المساعد بقسم الاعلام - كليه الآداب - جامعه & فاطمه الز & Y \\
\hline ملارس بقسم الاعلام شعبه صحافة - كليه الآداب - جامعه & & $Y Y$ \\
\hline 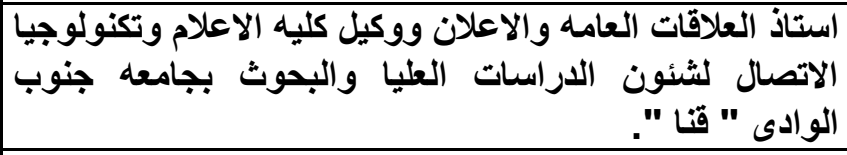 & محمد الز هزى & r \\
\hline الاتصال جامعه جنم الاذاعة والتلفزيون بكليه الاعلام وتكنولوجيا & عصيدة محد عبد العزيز & $Y \varepsilon$ \\
\hline جامعبه سوهاج الاعلامى - استاذ الصحافة والاعلام - كليه الآداب - & مرزوق عبد الحكم & ro \\
\hline " قدرس ". بقسم العلاقات العامه كليه الاعلام جامعه جنوب الوادى & مصطفى الجزيرى & Yq \\
\hline استاذ الصحافة والاعلام - كليه الآداب - جامعه المنيا & محمود حمدى & YV \\
\hline جنوب الوادى " قلألام وعميد كليه الأعلام وتكنولوجيا الاتصال بجامعه & هاله كمال نوقل & $r \Lambda$ \\
\hline 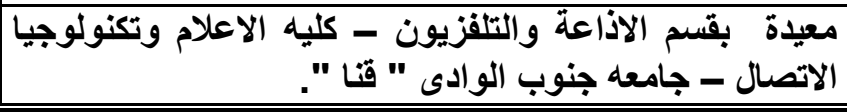 & هناء محمد عرب & pq \\
\hline
\end{tabular}

ثاتياً :- السادة مراسلحى الصحف القوميِة بالمؤسسات الصحفية (الأسماء مرثبه

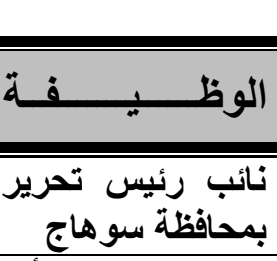

نائب رئيس تحريز جريدة الجمهورية ومدير مكتب الجمهورية صحفى بجريدة الأخبار ومدير مكتب الاخبار بمحافظة سوهاج

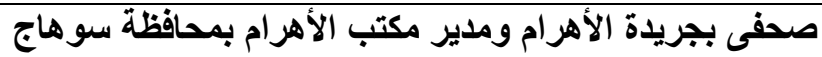

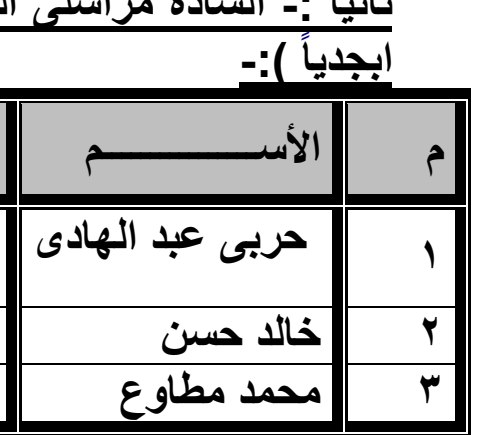


مجلة كلية الآداب، جامعة سوهاج، العدد الخمسون، الجزء الثاني، يناير 19 • ب م

\section{ملحق (Y) استمارة جمهور الخبراء}

جامعه سوهاج كلية الآداب

قسم الاعلام

شعبه صحافة - معام

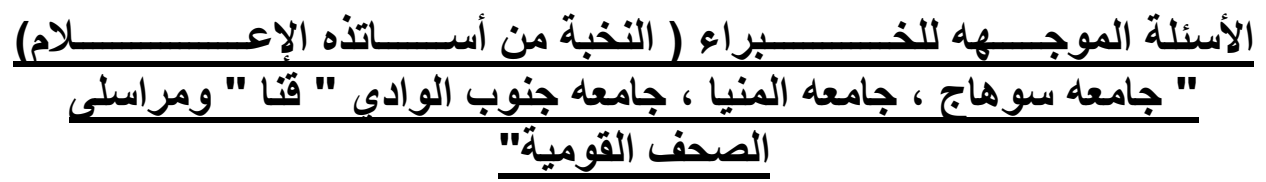

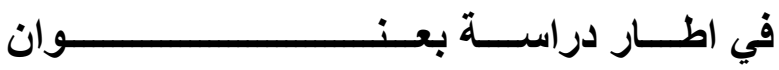

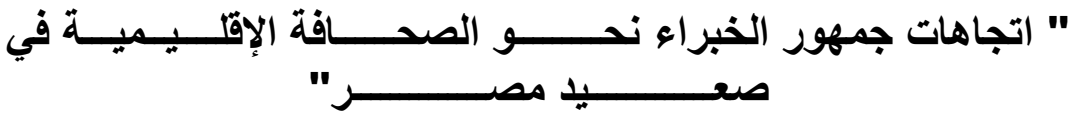

اعداد

نانسي صالح سالم ضيف الله

البيانات الواردة بهذه الأستمارة سرية، ولا تُستخدم إلا لأغراض البحث العلمي

$$
b^{r} \cdot 11 / / 1 \leq r q
$$


اتجاهات جمهور الخبراء نحو الصحافة الإقليمية في صعيد مصر .. دراسة ميدانية

( )ما هو تقيمك للمضمون المقدم فحى الصحافة الإقليمية ؟

r) ما هو رايك فحى طريقة معالجة الصحافة الإقليمية للقضايا المطروحة داخل

المحافظة ما

وب) هل اسلوب جلب الاعلانات فيى الصحافة الاقليمية يؤثر على المضمون المقدم

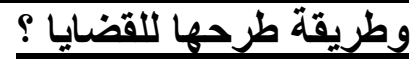

؟) ما هو تقيمك للقائم بالأتصال فى الصحافة الإقليمية ؟

0) وما هي مواصفات القائم بالاتصال فحى الصحافة الإقليمية من وجهه نظرك ؟

(7) من وجهه نظرك هل الصحافة الإقليمية لها دور فحى تنمية المجتمع المحلى؟

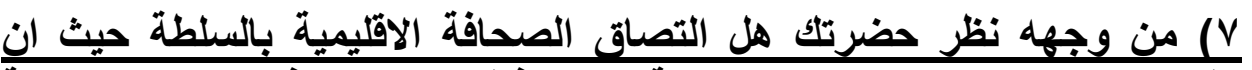

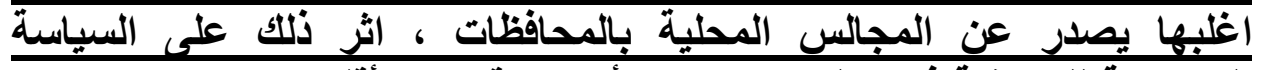

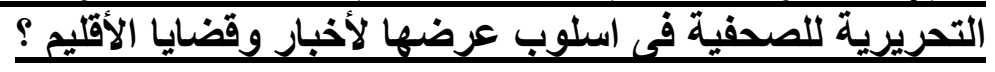

1) هل تعرض الصحافة الإقليمية المشكلات التحى تواجه المجتمع المحلى؟

9)- من وجه نظر حضرتك ما هي اهم المعوقات التى تواجه الصحافة الإقليمية

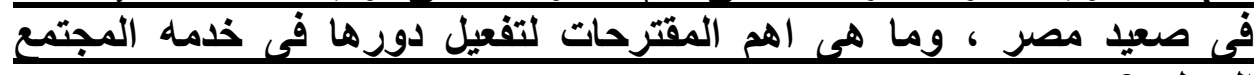
المحلمى

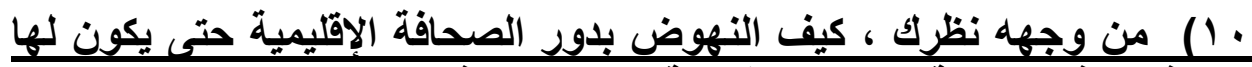

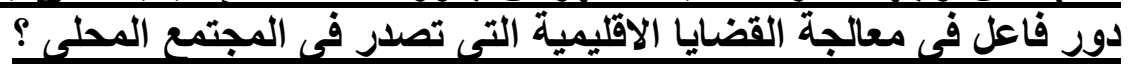

الباحثة

شكراً لكم لحسن تعاونكم،، 